Universidade de São Paulo

Faculdade de Educação

LEONARDO MACIEL MOREIRA

\title{
O Teatro em Museus e Centros de Ciências: uma Leitura na Perspectiva da Alfabetização Científica
}


LEONARDO MACIEL MOREIRA

O Teatro em Museus e Centros de Ciências: uma Leitura na Perspectiva da Alfabetização Científica

Tese apresentada ao Programa de PósGraduação em Educação da Faculdade de Educação da Universidade de São Paulo como requisito parcial para a obtenção do título de Doutor em Educação.

Área de concentração: Ensino de Ciências e Matemática.

Orientadora: Profa. Dra. Martha Marandino.

São Paulo

2013 
Autorizo a reprodução e divulgação total ou parcial deste trabalho, por qualquer meio convencional ou eletrônico, para fins de estudo e pesquisa, desde que citada a fonte.

\author{
Catalogação na Publicação \\ Serviço de Biblioteca e Documentação \\ Faculdade de Educação da Universidade de São Paulo
}

371.309 Moreira, Leonardo Maciel

M838d $O$ teatro em museus e centros de ciências : uma leitura na perspectiva da alfabetização científica / Leonardo Maciel Moreira ; orientação Martha Marandino. São Paulo : s.n., 2013.

180 p. : il., tabs.

Tese (Doutorado - Programa de Pós-Graduação em Educação. Área de Concentração : Ensino de Ciências e Matemática -Faculdade de Educação da Universidade de São Paulo)

1. Educação não-formal 2. Teatro 3. Educação em museus 4. Ciência

5. Exposições I. Marandino, Martha, orient. 
MOREIRA, L. M. O Teatro em Museus e Centros de Ciências: uma Leitura na Perspectiva da Alfabetização Científica. Tese apresentada ao Programa de PósGraduação em Educação da Faculdade de Educação da Universidade de São Paulo como requisito parcial para a obtenção do título de Doutor em Educação.

Aprovado em:

Banca Examinadora

Prof. Dr.

Instituição: Julgamento:

Assinatura:

Prof. Dr.

Instituição: Julgamento:

Assinatura:

Prof. Dr.

Instituição: Julgamento:

Assinatura:

Prof. Dr.

Instituição: Julgamento:

Assinatura:

Prof. Dr.

Instituição: Julgamento:

Assinatura: 


\section{AGRADECIMENTOS}

Aos meus pais, Maria de Lourdes Maciel Moreira e José de Souza Moreira, e meus irmãos, Leandro e Liana, pelo apoio, incentivo, compreensão e amor.

Ao meu tio José Afonso Maciel e sua família, por me receberem em sua casa e me apoiarem.

Aos amigos do Instituto Alana, em especial à Patrícia Lacombe, com os quais pude discutir, praticar e experienciar possibilidades de educação.

Aos amigos da Universidade Federal do Rio de Janeiro - Campus Macaé, pelo companheirismo e apoio.

Aos amigos do Grupo de Estudo e Pesquisa em Educação Não Formal e Divulgação em Ciência (GEENF) por dividirem comigo seus conhecimentos e visão de educação, auxiliando minha inserção no universo da educação não formal.

À Martha Marandino. Obrigado por dividir seus saberes, pelo incentivo e por acreditar e apoiar essa pesquisa.

A todos que colaboraram direta ou indiretamente para a realização desse trabalho. 
RESUMO

MOREIRA, L. M. O Teatro em Museus e Centros de Ciências: uma Leitura na Perspectiva da Alfabetização Científica. 2013. 180 f. Tese (DOUTORADO) Faculdade de Educação, Universidade de São Paulo, São Paulo, 2013.

Essa pesquisa tem como objetivo analisar articulações estabelecidas entre o Teatro nos Museus e Centros de Ciência e a alfabetização científica, no intuito de desvelar como peças teatrais do projeto Núcleo de Artes Cênicas da Estação Ciência (NAC), da Universidade de São Paulo, podem favorecer a alfabetização científica. Para isso focalizou-se em problematizar o Teatro enquanto ação de museus e centros de ciências, bem como suas possíveis interações com a exposição. A pesquisa foi realizada na perspectiva da análise qualitativa e foi realizada em duas etapas, um estudo exploratório e um estudo de caso. Os dados foram coletados por meio de questionário, entrevistas e análise de documentos (projeto submetido ao $\mathrm{CNPq}$, texto da peça, filmagem da encenação e relatório técnico). Os resultados encontrados demonstraram que a proposta de alfabetização científica implícita no NAC contempla as dimensões natureza da ciência e da tecnologia e a relação entre ciência, tecnologia, sociedade e meio ambiente. A dimensão conceitos e conhecimentos básicos da ciência e da tecnologia é contemplada em menor intensidade, salvo nos momentos em que o NAC se mobilizou para construir as denominadas aulas espetáculo. Especificamente com respeito ao espetáculo analisado os diversos sistemas cênicos são mobilizados na abordagem das diferentes dimensões da alfabetização científica, contribuindo para a construção de ideias a respeito da ciência e da tecnologia. Com respeito à relação do teatro com outras atividades museais, em especial a exposição, foi verificada uma relação de complementaridade, na qual o teatro assume a característica de, além de abordar a alfabetização científica nas diferentes categorias teóricas definidas nessa pesquisa, auxiliar as outras atividades nos ajustes que fossem necessários. Foi perceptível que a divisão das atribuições entre a encenação e a exposição não é rígida, o fato de uma informação ou aspecto da temática aparecer em uma estratégia não impediu que o mesmo aparecesse na outra.

Palavras-Chave: Educação não-formal, Teatro, Educação em Museus, Ciência, Exposições. 


\begin{abstract}
MOREIRA, L. M. The Theater in Museums and Science Centers: a Reading from the Perspective of Scientific Literacy. 2013. 180f. Tese (DOUTORADO) - Faculdade de Educação, Universidade de São Paulo, São Paulo, 2013.
\end{abstract}

This research aims to analyze relationships between Theater in Science Museums and the scientific literacy, to explicate how the theatre performed on Núcleo de Artes Cênicas (NAC), of the São Paulo University, can promote the scientific literacy. For this focused in problematizing the Theater while action of museums and science centers, as well as their possible interactions with the exhibition. This research was performed in looming of qualitative analysis and was performed in two steps, an exploratory study and a case study. The data were collected by questionnaires, interviews and analysis of documents (project submitted to the CNPq, the drama's text, videotaping of drama and technical report). The results demonstrated that the proposal for scientific literacy implicit in NAC contemplates the dimensions nature of science and technology and the relationship between science, technology, society and environment. The dimension concepts and basic knowledge of science and technology is contemplated in lesser intensity, except in moments in which the NAC mobilized to build the denominated classes spectacle. Specifically with respect to drama analyzed the different scenic systems are deployed in the approach of the different dimensions of scientific literacy, contributing to the construction of ideas about science and technology. With respect to the relationship of theater with other activities important museums, in particular the exhibition, it was verified a relationship of complementarity, in which the theater assumes the characteristic, in addition to addressing the scientific literacy in different theoretical categories defined in this study, the other auxiliary activities in adjustments that were necessary. It was noticeable that the division of tasks between the drama and the exhibition is not rigid, the fact of an information or aspect of the theme appears in a strategy did not prevent the same appeared in another.

Keywords: non-formal education, Theatre, Museum Educaiton, Science, Exhibitions. 


\section{LISTA DE FIGURAS}

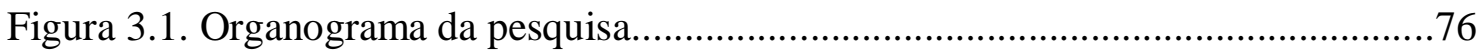

Figura 3.2: Futura Estação Ciência, década de 1940......................................................81

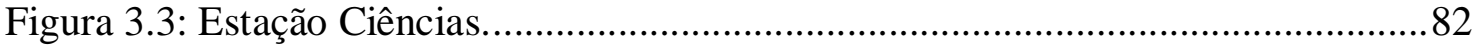

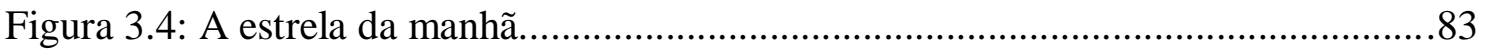

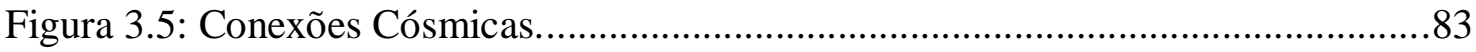

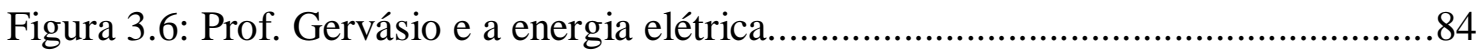

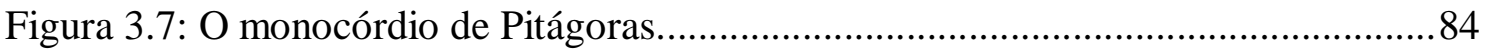

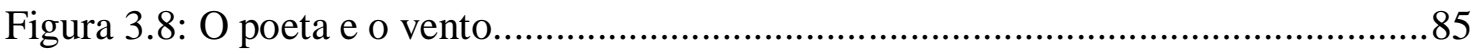

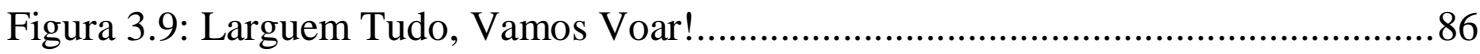

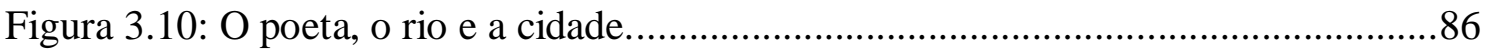

Figura 4.1: Panfleto de divulgação do espetáculo........................................................108

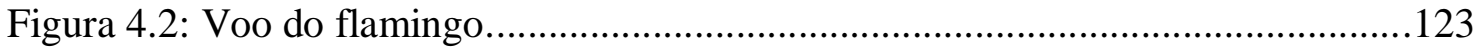

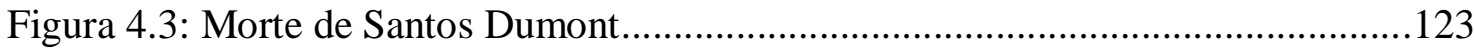

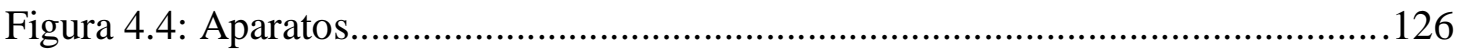

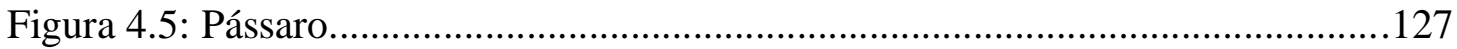

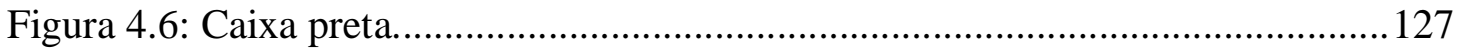

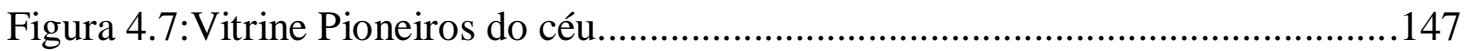

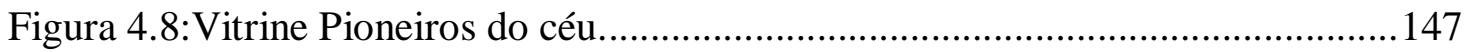

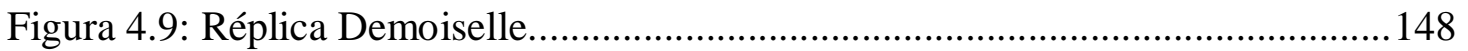

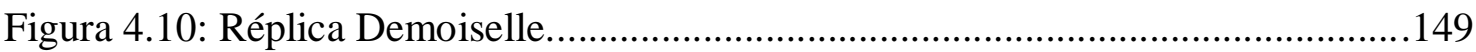

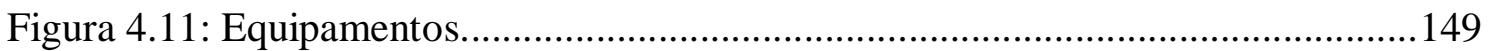

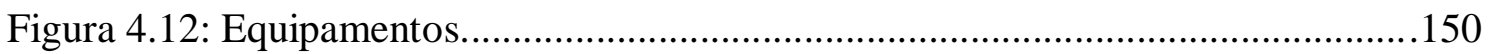

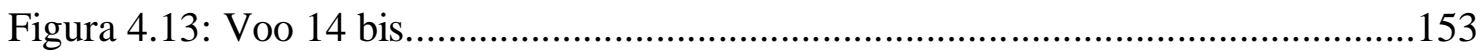

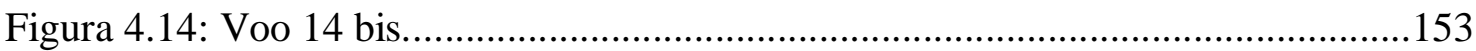




\section{LISTA DE TABELAS}

Tabela 4.1: Instituições respondentes com sinalização positiva.....................................91

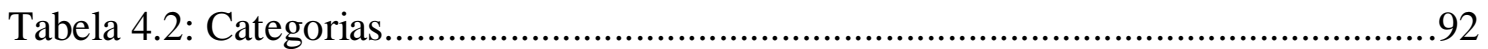




\section{SUMÁRIO}

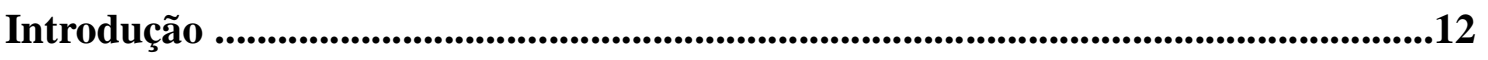

Alfabetização Científica: Perspectivas ............................................................................17

1.2 - Alfabetização, letramento ou enculturação? ................................................19

1.3 - A ideia de alfabetização científica ...............................................................22

1.4 - A relação ciência, tecnologia e sociedade ...................................................29

1.5 - Aprofundando as questões quanto à relação entre a ciência e a tecnologia ...34

1.6 - Os museus e centros de ciências e a alfabetização científica .........................38

1.7 - Categorias de análise ....................................................................43

O Teatro em Museus e Centros de Ciência .......................................................................47

2.1 - Entre a divulgação científica e a educação ..............................................49

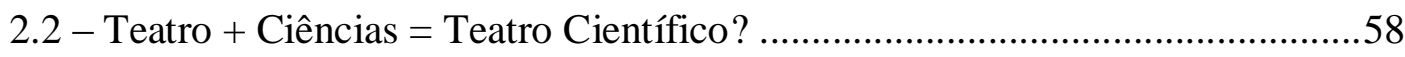

2.3 - Experiências de teatro e ciência no Brasil .....................................................68

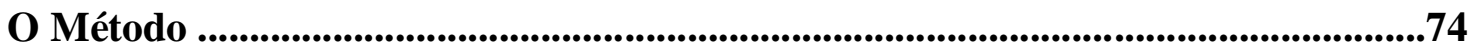

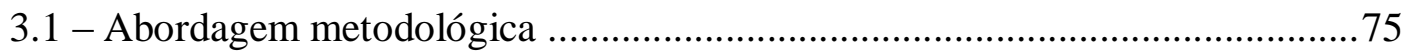

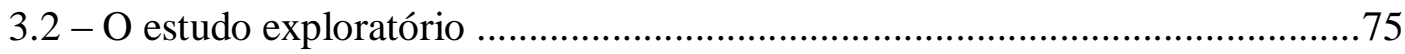

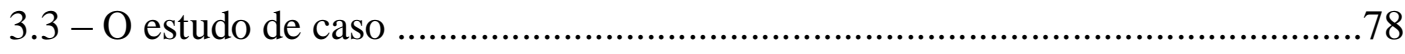

3.4 - Escolha do tema e caracterização do objeto ..............................................79

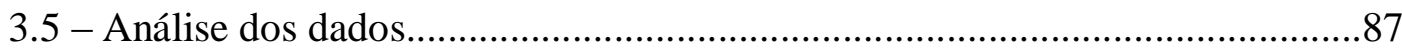

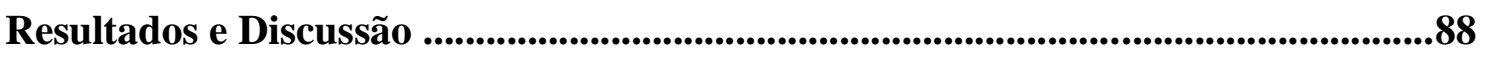

4.1 - Um panorama da relação entre o teatro e os museus e centros de ciências no

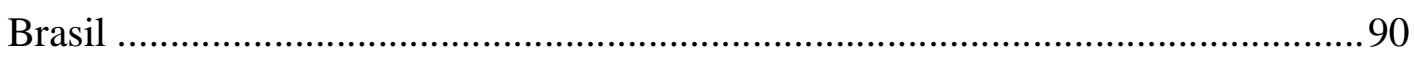


4.2 - O Fábula da Fíbula e o Vôo .94

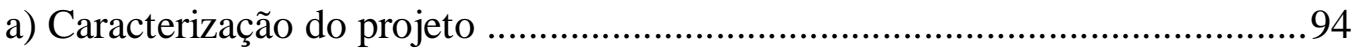

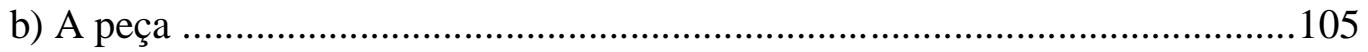

b.1) O texto da peça ......................................................................... 107

b.2) A encenação da peça ..................................................................116

c) O Voo no contexto da Estação Ciência .......................................................134

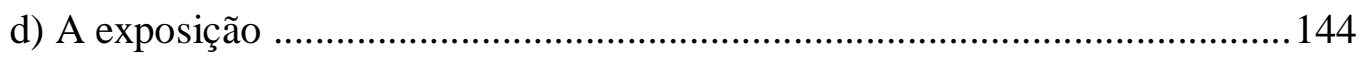

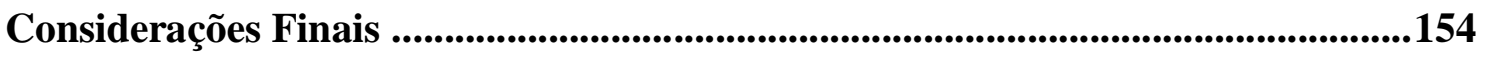

5.1 - O Teatro no Museu e a Alfabetização Científica ........................................155

5.2 - Teatro e Exposição nos Museus: Possíveis Articulações .............................158

5.3 - O Teatro no Museu: Arte, Educação ou Divulgação Científica? ..................159

Referências Bibliográficas ..........................................................................162

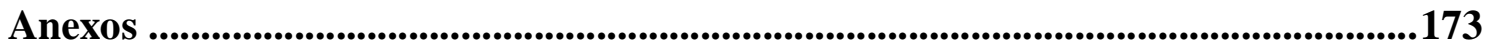




\section{INTRODUÇÃO}


A articulação entre sociedade e ciência se estabeleceu com a evolução da própria sociedade, como consequência da busca do Homem em modificar o ambiente de maneira que pudesse viver cada vez mais confortavelmente. O avanço tecnológico aumentou ainda mais essa interdependência, que se estende da utilização diária de produtos sintetizados pelo Homem até as inúmeras influências e impactos no desenvolvimento dos países, dos problemas referentes à qualidade de vida das pessoas aos efeitos ambientais das aplicações tecnológicas, refletindo-se em decisões solicitadas aos cidadãos quanto ao emprego de tais tecnologias. Por isso, como bem argumenta Chassot (2003), vale a pena conhecer um pouco de ciência para entender melhor o mundo que nos rodeia e para conscientizar-se das possibilidades de sua utilização e de sua interferência no nosso cotidiano. Com isso, é possível contribuir para a construção de uma visão crítica da ciência quanto aos impactos ambientais e sociais, bem como um posicionamento frente à relação custo/benefício e às decisões referentes aos investimentos nessa área (SANTOS \& SCHNETZLER, 2003). Essa formação em ciências, de caráter mais abrangente, para além da aprendizagem conceitual, vem sendo amplamente problematizada sob o viés da alfabetização científica.

A educação em ciências, na perspectiva da alfabetização científica, exige um processo contínuo, ao longo de toda a vida, e difícil de se encerrar no universo da escola, da educação formal. A escola é a responsável por auxiliar os educandos na construção dos primeiros conceitos científicos, entretanto os currículos, os programas e os horários impedem o acompanhamento do rápido desenvolvimento científico. Dessa maneira, conquanto se constate a essencialidade da educação formal no processo de alfabetização científica, percebe-se que, isolada, ela não é suficiente. Por isso a alfabetização científica torna-se dependente, também, da educação não-formal, através da qual os sujeitos poderão complementar sua cultura científica.

Nesse contexto, os Museus e Centros de Ciências despontam como espaços contribuintes para a alfabetização científica. Cazelli (2005) sinaliza que os museus de ciência vêm deixando de ser armazéns de objetos para tornarem-se lugares de aprendizagem ativa, num movimento simultâneo de olhar para as coleções e para o público. No qual o aspecto educacional, o papel pedagógico de cooperação com o ensino formal, foi se acentuando cada vez mais. Assim, gradativamente os museus 
foram se afastando do ideal de centros de comunicação e adquirindo também a função de complemento da formação promovida na escola. Durante a década de 1980, esses espaços foram ao encontro dos esforços em reduzir os níveis de analfabetismo científico, sendo considerados fonte importante de aprendizagem fora do âmbito escolar, que proporcionaria uma educação continuada em ciências após o término da educação formal.

No intuito de possibilitar uma maior interação e comunicação com os visitantes os museus têm recorrido a um conjunto de técnicas de comunicação, tais como computadores, vídeos, painéis animados, teatro e outros. As novas propostas decorrem do perfil dos visitantes que, cada vez mais, desejam participar de forma ativa e interativa com as exposições. Nesse contexto os museus e centros de ciências têm se mostrado como um lugar favorável à alfabetização científica. Assim, torna-se importante olhar para esses espaços e explicitar em que medida as atividades por eles desenvolvidas podem contribuir para a alfabetização científica do público visitante.

Alguns autores têm ressaltado a importância da linguagem teatral, enquanto meio, para divulgar e popularizar a ciência (MATEUS, 2003; MONTENEGRO, 2005). Lopes (2005) considera que é na relação entre ciência e sociedade que a arte pode contribuir com os museus e centros de ciência, uma vez que, por meio da linguagem artística, é possível apresentar acontecimentos da ciência e da vida de cientistas, relacionando-os ao ambiente social em que estão inseridos: o teatro, por exemplo, pode contextualizar social, histórica e politicamente a prática científica através da reprodução e problematização de episódios do mundo real. A arte poderia ajudar a popularizar a ciência porque confere emoção aos seus temas.

Conquanto a literatura aponte para uma proficuidade da articulação entre teatro e ciências, visando à divulgação científica, essa articulação ainda é recente e, por isso, apresenta diversos aspectos que precisam ser mais bem estudados e problematizados. Por exemplo, a incorporação do teatro pelos museus e centros de ciências brasileiros enquanto estratégia para a divulgação científica é recente, não existindo uma massa crítica de pesquisas que se proponham a analisar como essa apropriação se deu, bem como a delinear as características do teatro no contexto dos museus e centros de ciências. Essas lacunas dificultam a explicitação e o conhecimento das possibilidades e limitações dessa atividade e impossibilita o diálogo com vivências e resultados encontrados por pesquisadores de outros países. 
A apreciação de métodos empregados na promoção da divulgação científica através do teatro torna-se importante na atualidade, uma vez que tanto museus e centros de ciências quanto professores de ciências - da educação básica e do ensino superior recorrem a essa estratégia. Nesse aspecto, uma análise sistematizada desse recurso torna-se imprescindível para a melhoria do processo de divulgação em ciências. Também há que se considerar que a pesquisa na interface educação, ciência e teatro é indispensável para que essa temática seja discutida com fundamentação científica, para que se tenha uma maior difusão em revistas de pesquisa e para que sejam produzidas orientações que auxiliem curadores, professores e pesquisadores interessados em desenvolver projetos nesse âmbito.

O trabalho de pesquisa aqui apresentado é fruto também de inquietações pessoais com respeito a relação entre educação, ciências e teatro. Já há algum tempo procuro questionar, investigar e praticar a articulação entre esses três campos. Esse processo teve início no período de minha graduação em Licenciatura em Química. Naquela época já acumulava experiências em práticas do teatro escola, e me questionava quanto a possibilidade de se trabalhar com textos teatrais visando discussões sobre ciências. Depois, no mestrado, essas reflexões se materializaram na dissertação O jogo teatral no ensino de química: contribuições para a construção da cidadania. Nesse trabalho desenvolvi uma pesquisa na qual procurei entender e problematizar a relação educação, ciência e teatro no âmbito da educação formal. Nele pude propor e analisar a adaptação de uma técnica de aprendizagem de teatro (Jogos Teatrais) visando à abordagem de conceitos e temáticas científicas. No doutorado iniciei questionamentos a respeito da relação entre educação, ciência e teatro no âmbito da educação não-formal. E com o ingresso como docente na Universidade Federal do Rio de Janeiro - Campus Macaé, tornando-me criador e coordenador do Projeto Ciênica, que se destina a divulgar a ciência por meio do teatro, as reflexões sobre as problemáticas envolvidas na relação entre esses campos tornaram-se maiores. Assim, o trabalho de pesquisa aqui apresentado é resultado da necessidade e da vontade de contribuir para a produção de conhecimentos na interface educação, ciência e teatro, tendo como objetivo geral analisar articulações estabelecidas entre o Teatro nos Museus e Centros de Ciência e a alfabetização científica, no intuito de desvelar como peças 
teatrais do projeto Núcleo de Artes Cênicas da Estação Ciência da USP poderiam favorecer a alfabetização científica.

Nesse intuito é que no capítulo Alfabetização científica: Perspectivas problematizaremos o termo alfabetização científica e anunciaremos a concepção que adotaremos nessa pesquisa. Apresentaremos uma discussão sobre os Museus e Centros de Ciências enquanto espaços de alfabetização científica e explicitaremos as categorias de análise que utilizaremos na leitura dos dados.

No capítulo O Teatro em Museus e Centros de Ciência analisaremos a incorporação do teatro enquanto atividade museal e discutiremos sobre as ações que têm sido denominadas de teatro científico, buscando explicitar as definições que diversos autores propõem para essas ações e as problemáticas dessa prática.

No capítulo Método será descrito o método utilizado na realização desta pesquisa. Explicita-se a maneira como os dados foram coletados e tratados, o processo de escolha da temática desenvolvida e a escolha e caracterização do projeto colaborador.

No capítulo Resultados e discussão serão explicitados e problematizados os aspectos da alfabetização científica favorecidos pelo espetáculo, confrontando-se as informações coletadas com as categorias teóricas. Também caracterizaremos o teatro enquanto atividade museal. Focalizando a conscientização e a apropriação da perspectiva da alfabetização científica pelos realizadores dessa atividade, bem como na maneira como essa apropriação é materializada em espetáculo. 
Alfabetização Científica:
Perspectivas 
Neste capítulo, em um primeiro momento problematizaremos o próprio termo alfabetização científica em si, bem como as denominações correlacionadas a ele, quais sejam o letramento científico e a enculturação científica. Após, discutiremos definições e propostas de alfabetização científica e anunciaremos a concepção que adotaremos nessa pesquisa. Posteriormente, abordaremos a relação entre alfabetização científica e o movimento Ciência, Tecnologia e Sociedade, situando as perspectivas do segundo no bojo das proposições do primeiro. Na explicitação dessa relação intencionamos apurar o entendimento que temos da ideia de alfabetização científica. Em seguida, apresentaremos uma discussão sobre os Museus e Centros de Ciências enquanto espaços de alfabetização científica, procurando anunciar questões de investigação que permeiam essa pesquisa. Por fim, explicitaremos as categorias teóricas que utilizaremos na análise dos dados, estas sendo resultantes da literatura consultada. 


\section{2 - Alfabetização, letramento ou enculturação?}

A alfabetização científica vem sendo discutida por vários estudiosos e pesquisadores do ensino das ciências. No Brasil e em Portugal, esse termo é traduzido do termo inglês scientific literacy. É importante destacar que a tradução correta deveria ser "alfabetismo" e não alfabetização, entretanto, opta-se por manter a tradução "alfabetização" uma vez que esta transmite um significado de continuidade - a alfabetização científica é um processo, uma atividade vitalícia (LORENZETTI \& DELIZOICOV, 2001). Ressalta-se ainda a existência de uma polêmica em torno de utilizar alfabetização científica ou letramento científico em português, e que essa possível divergência é herança da discussão sobre os conceitos alfabetização e letramento. De acordo com Soares (2004) existem fortes argumentos para que esses dois termos sejam tanto equivalentes como diferenciados. Para que sejam equivalentes, é necessário que se redefina o conceito tradicional de alfabetização.

A diferenciação entre alfabetização e letramento surgiu da necessidade de reconhecer e nomear práticas sociais de leitura e de escrita mais avançadas e complexas do que as práticas do ler e do escrever resultantes da simples aprendizagem do sistema de escrita. No Brasil, os conceitos de alfabetização e letramento frequentemente se confundem. Soares (2004) exemplifica essa realidade através da análise dos Censos Demográficos: o conceito de alfabetizado, que vigorou até o Censo de 1940, correspondia ao sujeito que declarava saber ler e escrever (interpretado como capacidade de escrever o próprio nome); depois, alfabetizado passou a denominar o sujeito capaz de ler e escrever um bilhete simples (o que inclui a prática da leitura e escrita, mesmo que de forma simples); atualmente, os resultados do Censo têm sido apresentados pelo critério de anos de escolarização, em função dos quais se caracteriza o nível de alfabetização funcional da população (subentende-se que, após alguns anos de aprendizagem escolar, o indivíduo terá não só aprendido a ler e escrever, mas também a fazer uso da leitura e da escrita). Soares (2004) apresenta três propostas para que se chegue a um consenso sobre os termos alfabetização e letramento: (i) é necessário reconhecer a especificidade da alfabetização, entendida como processo de aquisição e apropriação do sistema da escrita, alfabético e ortográfico; (ii) é importante ter a consciência de que a alfabetização deve se desenvolver em um contexto de letramento (entendido como a participação em eventos variados de leitura e de escrita e 
o consequente desenvolvimento de habilidades de uso da leitura e da escrita nas práticas sociais que envolvam a língua escrita); (iii) o reconhecimento de que tanto a alfabetização, quanto o letramento, têm diferentes dimensões e, por isso, cada um deles demanda uma metodologia diferente.

Sasseron e Carvalho (2011) fomentam a discussão acrescentando que além da tradução do termo inglês scientific literacy, os autores brasileiros utilizam-se da tradução direta alfabetização científica dos termos espanhol e francês, respectivamente, alfabetización científica e alphabétisation scientifique. E, ainda, em alguns documentos da UNESCO o termo literacy é traduzido como cultura e não alfabetização. Alguns autores francofônicos ainda o traduzem como a expressão la culture scientifique. Devido a essa pluralidade semântica, encontra-se na literatura brasileira sobre ensino de ciências os termos letramento científico, alfabetização científica e enculturação científica.

A utilização do termo enculturação científica tem sido justificada pela proposição de que as noções, ideias e conceitos científicos devem ser parte da cultura do sujeito da mesma maneira que outros construtos culturais, tais como a cultura religiosa, social e histórica. Os autores que utilizam a expressão letramento científico apoiam-se na diferenciação rígida entre letramento e alfabetização. Já os autores que utilizam o termo alfabetização científica o fazem adotando uma ideia expandida de alfabetização, identificando-a com o próprio letramento. Sasseron e Carvalho (2008; 2011), assim como nós, enquadram-se nesse último grupo. Essa perspectiva expandida de alfabetização fundamenta-se, em geral, nas ideias do educador Paulo Freire (1980; 1996). Para este autor, alfabetização não se limita ao reconhecimento de signos e ao entendimento dos seus significados, mas também procura desenvolver a consciência crítica dos sujeitos quanto à sociedade e ao papel de cada um deles nela. A meta é a superação da compreensão ingênua da realidade e a adoção de uma perspectiva dominantemente crítica.

O termo alfabetização científica e tecnológica (ACT) também vem sendo utilizado na literatura da área. De acordo com Auler e Delizoicov (2001), a ideia de ACT surge da perspectiva de que a sociedade é analfabeta científica e tecnologicamente, e de que a dependência social aos avanços científico-tecnológicos cria a necessidade de democratização desses conhecimentos. De acordo com estes autores a ACT pode ser 
concebida nas perspectivas reducionista e ampliada. Na perspectiva reducionista, ACT limita-se ao ensino de conceitos e ao entendimento dos artefatos tecnológicos e científicos tão somente na dimensão técnica. Aqui não há lugar para discussões acerca das implicações da Ciência e da Tecnologia (CT) na sociedade. Como pressupostos deste modelo estão a ideia de ignorância sobre questões científicas e tecnológicas; a visão de mundo oferecida pela ciência como sendo única e privilegiada, sendo fator essencial para a melhoria das condições humanas e ambientais; e a neutralidade da ciência, na qual as condições de construção e validação do conhecimento científico não são questionadas e a ciência é tida como desprovida de ambigüidades e contradições. Já a ACT ampliada contempla o ensino de conceitos associado à compreensão das interações entre ciência, tecnologia e sociedade. O que implica o desvelamento dos mitos vinculados à $\mathrm{CT}$ e na discussão a respeito da dinâmica de produção e de apropriação do conhecimento científico-tecnológico. Auler (2003) defende que a ACT deve propiciar a leitura crítica do mundo contemporâneo, cuja dinâmica está relacionada ao desenvolvimento científico-tecnológico, potencializando para uma ação no sentido de sua transformação.

Apesar de termos identificado na literatura o movimento de se criar um novo termo que agrega ambas dimensões, alfabetização científica e tecnológica, percebe-se que a função dessa proposta é a de promover o reconhecimento da tecnologia enquanto construto diferenciado da ciência, bem como explicitar a importância de se aprender conhecimentos, práticas e valores relativos à tecnologia e suas implicações sociais. Fourez (1995) pondera que a proposição de uma alfabetização tecnológica explicita um combate onde estão em jogo interesses dos "cientistas puros" e aqueles que querem colocar a ciência no rol dos fundamentos ideológicos (mito fundamental). Esse mesmo autor destaca que a hegemonia dos cursos de ciências puras, o desinteresse dos alunos por estes cursos e as necessidades culturais e econômicas de uma aproximação com o desenvolvimento tecnológico, tem fortalecido o reforço do aspecto tecnológico, o que garantiria que se contemplasse uma alfabetização tecnológica, ao menos em algum momento. Ao que parece, a alfabetização tecnológica carrega consigo o discurso de reafirmação e de reconhecimento de um campo que, cada vez mais, tem se consolidado socialmente, a tecnologia. 
Conquanto haja o embate supracitado, é perceptível que diversos autores, dentre eles Bybee (1995), Hazen e Trefil (1995), Leal e Souza (1997) e Sasseron e Carvalho (2008), dentre outros, consideram a tecnologia em suas propostas de AC. Assim, nessa pesquisa assumiremos como concepção de alfabetização científica a inclusão e o englobamento das problemáticas referentes à tecnologia.

\section{3 - A ideia de Alfabetização Científica.}

O primeiro registro que se tem sobre uma discussão a respeito do que vem sendo denominado de alfabetização científica é o livro Scientific Literacy: Its Meaning for American Schools, de Paul Hurd, publicado em 1958 (SASSERON, 2008). Em artigo publicado posteriormente, Hurd (1998) retoma a ideia de alfabetização científica sinalizando personalidades que, ao longo da história, difundiram ideias convergentes com essa proposta. Cita o filósofo Francis Bacon, em 1620, que alegava que o bom uso das faculdades intelectuais se daria por meio de conhecimentos sobre as ciências; $\mathrm{O}$ vice-presidente dos Estados Unidos da América, Thomas Jefferson, em 1798, que reivindicou o ensino das ciências em quaisquer níveis escolares; o também filósofo Herbert Spencer, em 1859, defensor de que é necessário a sociedade saber mais coisas sobre a ciência em si e sobre seus empreendimentos, já que ela depende dos conhecimentos que a ciência constrói; e James Wilkinson, membro do Royal College of Surgeons of London, em 1847, que ponderou que os objetivos que movem os cientistas são diferentes dos objetivos daqueles que buscam aplicações para os conhecimentos científicos. E como na escola somente o resultado dos trabalhos de cientistas é apresentado aos alunos e não a aplicação, a compreensão das ciências acaba tornando-se mais difícil.

Hurd (1998) destaca como períodos históricos que contribuíram para a construção da proposta de alfabetização científica as modificações dos currículos de ciências nos Estados Unidos da América, década de 1930, quando a perspectiva de que o currículo deveria contemplar o impacto do progresso científico e tecnológico na vida, na sociedade e na cultura, começa a ser disseminada naquela nação. Outro período é o pós Segunda Guerra Mundial, quando alterações na prática científica representaram impactos para a dimensão social, econômica e política de diversos países. Nesse segundo período, em especial, percebeu-se a preocupação dos países desenvolvidos em formar estudantes com desejos e habilidades para trabalhar na pesquisa científica. 
Laugksch (2000) denomina as décadas de 1950 e 1960 como o período de legitimação da ideia de alfabetização científica, conquanto o conceito em si ainda não estivesse claramente definido.

Laugksch (2000) realiza uma abordagem histórica na tentativa de definir a alfabetização científica. Nos trabalhos por ele considerados estão o de Pella et all (1966), para os quais uma pessoa alfabetizada cientificamente deve possuir conhecimentos das relações entre ciência e sociedade, da ética científica, da natureza da ciência, diferenciar ciência de tecnologia, possuir conhecimento sobre conceitos científicos básicos e entender as relações entre as ciências e as humanidades, também tratam da importância de conferir liberdade intelectual aos alunos. Este último auxiliaria no desenvolvimento de todo o processo da alfabetização científica. Hazen e Trefil (1991), propondo que a alfabetização científica é o conhecimento que devemos possuir para entender os resultados divulgados pela ciência, defendendo uma distinção entre fazer ciência e usar ciência. Para estes autores não é necessário que a população saiba fazer pesquisa científica, mas deve saber como os novos conhecimentos produzidos pelos cientistas podem trazer avanços e consequências para sua vida e sociedade. Shamos (apud LAUGKSCH, 2000), que considera três extensões para a AC: cultural, funcional e verdadeira. A primeira refere-se ao conhecimento da cultura científica, englobando a leitura de como os construtos científicos se relacionam com a sociedade; a segunda, funcional, envolve o conhecimento sobre conceitos e ideais científicas e sua utilização de maneira adequada para se comunicar, ler e construir novos significados; e a verdadeira contempla o entendimento de como uma investigação científica acontece e o apreço pela natureza da ciência. Miller apresenta três dimensões para a AC: o entendimento da natureza da ciência, a compreensão de termos e conceitos-chave das ciências e o entendimento dos impactos das ciências e suas tecnologias.

Outros autores também propõem diferentes dimensões de alfabetização científica. Por exemplo, para Shen (1975) ela pode abranger saberes tão variados como o preparo de uma refeição nutritiva até a apreciação das leis da físico-química. Esse autor distingue três noções de alfabetização científica, alfabetização científica prática, cívica e cultural. A alfabetização científica prática capacita o sujeito para resolver problemas básicos de sua vida, está relacionada às necessidades humanas mais básicas tais como alimentação, saúde e habitação. Ela possibilita que os sujeitos possam tomar decisões de 
forma consciente, mudando seus hábitos, preservando sua saúde e exigindo condições dignas para a sua vida e a dos demais seres. A alfabetização científica cívica tem o foco na ciência e seus problemas, proporcionando aos cidadãos e seus representantes conhecimentos que lhes permitam a tomada de decisões de maneira mais fundamentada cientificamente. E a alfabetização científica cultural, que motiva desejo de conhecer a ciência de forma mais aprofundada e não se destina diretamente à resolução de problemas práticos. É uma apreciação da ciência enquanto construto humano. Geralmente, é praticada por profissionais não pertencentes à área científica que se interessam por um dado assunto e começam a ler, pensar e assinar revistas específicas para aprimorar seu conhecimento.

Na proposta de Shen (1975), percebe-se um aumento no nível de complexidade da alfabetização científica na diferenciação entre as dimensões. $\mathrm{Na}$ AC prática os conhecimentos científicos e tecnológicos são ferramentas para a resolução de problemáticas do cotidiano, no entanto, não há aprofundamento no conhecimento dos construtos científicos mobilizados para a resolução das problemáticas, tudo se dá no nível do imediatismo. Já na AC cívica, há dois movimentos em direções diferentes, um rumo ao aprofundamento conceitual, que levaria à fundamentação teórica necessária para a construção de argumentos convincentes e defesa de ponto de vista, e outro rumo a uma prática democrática, preparatória para a participação em assembleias decisórias. Por fim, a AC cultural propõe um rompimento, a modificação da própria relação do sujeito com o conhecimento científico e tecnológico. Aqui, a ciência e a tecnologia deixam de ser vistas como algo de utilidade prática, como ferramenta, e passam a ser consideradas como parte da cultura. Ou seja, elas entrariam para o rol de hábitos, de pensamentos, de crenças e de visão de mundo dos sujeitos, e o aprofundamento do conhecimento se daria pela vivência da cultura.

Bybee (1995) também apresenta três dimensões de alfabetização científica: a funcional, a conceitual e processual e a multidimensional. A alfabetização científica funcional centra-se na aquisição de um vocabulário científico que permita aos estudantes a percepção de que a Ciência utiliza palavras apropriadas e adequadas. $\mathrm{Na}$ alfabetização científica conceitual e processual, os educandos já atribuem significados próprios aos conceitos científicos, relacionando informações e fatos sobre ciência e tecnologia. Ela inclui habilidades e compreensões relativas aos procedimentos e 
processos que fazem da ciência um dos caminhos para o conhecimento, ou seja, não se dicotomizam os processos e os produtos da ciência. No nível de alfabetização científica multidimensional os sujeitos são capazes de adquirir e explicar conhecimentos, além de aplicá-los à solução de problemas do dia-a-dia. Esse grau de alfabetização científica é desenvolvido pela abordagem de perspectivas de ciência e tecnologia que incluem a história das ideias científicas, a natureza da ciência e da tecnologia, e o papel da ciência e da tecnologia na vida pessoal e na sociedade.

$\mathrm{Na}$ proposta de Bybee (1995), percebe-se um movimento de crescente significação dos conceitos e conhecimentos científicos e tecnológicos. Na primeira dimensão a significação se dá no nível do reconhecimento dos signos, isto é, das palavras e símbolos que povoam o universo da ciência e da tecnologia. O emprego correto de uma "gramática científica" está implícito nessa dimensão de AC. Na segunda dimensão é que haverá um aprofundamento dos conceitos e conhecimentos e uma significação mais fina. Entendemos que a passagem para esse segundo nível envolve a depuração de perspectivas pessoais sobre os conceitos e conhecimentos científicos de maneira a aproximar a significação dos sujeitos à significação cientificamente aceita. $\mathrm{Na}$ terceira dimensão a significação é apurada em um processo divergente, no qual há um refinamento dos conceitos e conhecimentos científicos e tecnológicos por sua contextualização na história e nos âmbitos social, cotidiano e epistemológico.

Leal e Souza (1997) entendem a alfabetização científica como sendo aquilo que um público específico (o público escolar) deve saber sobre ciência, tecnologia e sociedade com base em conhecimentos adquiridos em contextos diversos (escola, museu, revista, etc.). Já Hurd (1998) considera que ela envolve a produção e utilização da Ciência na vida do homem, provocando mudanças revolucionárias na Ciência com dimensões na democracia, no progresso social e nas necessidades de adaptação do ser humano (as características de uma pessoa cientificamente instruída são desenvolvidas quando os estudantes são chamados a solucionar problemas, a realizar investigações, a desenvolver projetos em laboratório de apoio e experiências de campo). Hazen e Trefil (1995) a definem como o conhecimento necessário para entender os debates públicos sobre as questões de ciência e tecnologia. Ela envolve um conjunto de fatos, vocabulários, conceitos, história e filosofia do conhecimento científico. Krasilchik e Marandino (2001) consideram que ao se pensar a Alfabetização Científica, deve-se ter 
em mente a ciência como parte da cultura e, por isso, envolve discussões tanto sobre como seus conhecimentos foram sendo construídos ao longo dos anos, quanto aos debates acerca de avanços e prejuízos que suas tecnologias possam ter nos trazido. Chassot (2003a; 2003b) a considera como sendo o conjunto de conhecimentos que facilitaria uma leitura do mundo onde se vive. Para ele, a ciência é uma linguagem, ser alfabetizado cientificamente é saber ler a natureza através desta linguagem (o analfabeto científico é o sujeito incapaz de uma leitura do universo através da linguagem científica). Mas ela também deve propiciar uma perspectiva de inclusão social, seria "desejável que os alfabetizados cientificamente não apenas tivessem facilitada a leitura do mundo em que vivem, mas entendessem as necessidades de transformá-lo para melhor" (CHASSOT, 2003b, p.37).

Do que emerge da literatura, parece haver um consenso na direção de que alfabetização científica significa adquirir os conhecimentos científicos e tecnológicos necessários para o desenvolvimento da vida diária, para ajudar a resolver os problemas e as necessidades de saúde e sobrevivência básica, conscientizar-se e posicionar-se politicamente diante das complexas relações entre a ciência, a tecnologia e a sociedade.

De acordo com Lorenzetti e Delizoicov (2001) uma concepção de alfabetização científica muito utilizada em artigos de pesquisa é a definida por Miller:

“... quando se fala em alfabetização, normalmente não se percebe que a expressão ser alfabetizado apresenta dois significados diferentes: um, mais denso, estabelece uma relação com a cultura, a erudição. Por conseguinte, o indivíduo alfabetizado é aquele que é culto, erudito, ilustrado. $\mathrm{O}$ outro fica reduzido à capacidade de ler e escrever”. (Miller apud Lorenzetti \& Delizoicov, p.03, 2001).

Alguns autores elencam as habilidades de um sujeito alfabetizado cientificamente. Para Arons (apud CAZELLI, 1992) esse sujeito deve:

1) compreender a distinção entre observação e inferência, isto é, o exame minucioso e a dedução pelo raciocínio; 
2) distinguir entre o papel ocasional da descoberta acidental na investigação científica e a estratégia deliberada de formular testes e hipóteses;

3) entender, através de exemplos específicos, que conceitos científicos e teorias são mutáveis e provisórios em vez de definitivos e inalteráveis, e perceber a maneira pela qual tais estruturas são continuamente aperfeiçoadas ou aprimoradas;

4) reconhecer que os conceitos científicos (por ex: velocidade, aceleração, força, energia, carga elétrica, massa gravitacional e inércia) são inventados ou criados por atos da inteligência e da imaginação humana e não são objetos tangíveis, descobertos acidentalmente, como um fóssil, uma nova espécie de planta ou um mineral particular;

5) reconhecer que para serem entendidos e corretamente usados, tais termos requerem cuidadosa definição operacional, normalmente originada através de experiências. Em outras palavras, compreender que um conceito científico envolve uma ideia antes e um nome depois, e que o entendimento não resite no próprio termo técnico;

6) desenvolver conhecimento e entendimentos suficientemente básicos em algumas áreas de interesse para permitir uma leitura inteligente e aprendizagem subsequente sem instrução formal;

7) estar ciente de alguns exemplos específicos de interação entre a ciência e sociedade, nos planos morais, éticos e sociais, bem como do impacto do conhecimento científico.(CAZELLI, 1992, p.37-38)

A partir da proposta de Arons, Cazelli (1992) identifica três elementos como constitutivos da alfabetização científica: o conhecimento sobre os processos do estudo científico, sobre a estruturação dos conceitos científicos básicos e a conscientização do impacto da ciência e da tecnologia na sociedade. 
Para Hurd (1998), um sujeito alfabetizado cientificamente percebe a distinção entre especialistas e desinformados e entre ciência e pseudociência; Entende que as ciências e tecnologias têm dimensões política, judicial e ética e, por isso, os problemas envolvendo esses campos podem ter mais do que uma resposta "correta"; Reconhece a influência da ciência e da tecnologia em sua vida e os riscos, limites e probabilidades na tomada de decisões envolvendo um conhecimento científico ou tecnológico; Entende os procedimentos da pesquisa científica e possui a competência de analisar e processar informações para gerar conhecimentos para além dos fatos; Mobiliza os conhecimentos científicos e tecnológicos em situações de tomada de decisões em sua vida particular e em assembleias democráticas. Reconhece os pesquisadores como produtores de conhecimentos científicos e os cidadãos como usuários desse conhecimento, a característica do conhecimento científico de estar em constante construção e identifica as situações em que a relação de causa e efeito não pode ser construída; Entende a importância da pesquisa por si própria como um produto da curiosidade do cientista.

Já Fourez (apud SASSERON e CARVALHO, 2008) propõe que uma pessoa alfabetizada cientificamente e tecnologicamente conhece os principais conceitos, hipóteses e teorias científicas e é capaz de aplicá-los em situações de tomada de decisões no dia-a-dia. Conhece as fontes válidas de informação científica e tecnológica e recorre a elas quando diante de situações de tomada de decisões. Compreende que a sociedade exerce controle sobre as ciências e as tecnologias, bem como as ciências e as tecnologias refletem a sociedade. Reconhece os limites da utilidade das ciências e das tecnologias para o progresso do bem-estar humano. Compreende que a produção dos saberes científicos depende de processos de pesquisas e de conceitos teóricos e reconhece que o saber científico é provisório, sendo uma construção histórica. Compreende as aplicações das tecnologias e as decisões implicadas nestas utilizações. Aprecia o valor da pesquisa, do desenvolvimento tecnológico e a estimulação intelectual que as ciências e as tecnologias suscitam. Extrai da formação científica uma visão de mundo mais rica e interessante.

Em linhas gerais, percebe-se as congruência entre as perspectivas de Arons, Hurd e Fourez. Estão presentes nessas propostas o conhecimento dos principais conceitos da ciência e da tecnologia, bem como o conhecimento dos processos da ciência e da tecnologia, seus impactos na vida cotidiana e a aplicação dos conceitos científicos e 
tecnológicos em situações de tomada de decisão. Sasseron e Carvalho (2011), após revisão realizada sobre a alfabetização científica, procurando identificar as habilidades tidas como necessárias aos sujeitos alfabetizados cientificamente, propõem a existência de três eixos estruturantes da alfabetização científica: $O$ primeiro refere-se à compreensão básica de termos, conhecimentos e conceitos científicos fundamentais. Esta compreensão engloba a aplicação dos conhecimentos e conceitos às diversas situações do dia-a-dia; O segundo eixo é a compreensão da natureza das ciências e dos fatores éticos e políticos que circundam sua prática. Nesse eixo está o reconhecimento da ciência e da tecnologia como um corpo de conhecimentos em transformação por meio da aquisição de novos dados decorrentes da análise, síntese e decodificação de resultados de pesquisas, que originam os saberes. O terceiro eixo compreende o entendimento das relações existentes entre ciência, tecnologia, sociedade e meioambiente.

A identificação desse último eixo sugere que o movimento ciência, tecnologia e sociedade (CTS) está contemplado na proposta da alfabetização científica. De fato, diversos autores consideram que o objetivo da proposta CTS na educação é desenvolver a alfabetização científica e tecnológica dos cidadãos, auxiliando na construção de conhecimentos, habilidades e valores necessários à tomada de decisões sobre assuntos de ciência e de tecnologia na sociedade e atuar na solução desses assuntos (AIKENHEAD, 1990, 2003; IGLESIA, 1995; HOLMAN, 1988; ZOLLER, 1982; RICARDO, 2007; SANTOS E MORTIMER, 2002;). Assim, o conhecimento das características desse movimento nos permite entender melhor a própria ideia de alfabetização científica.

\section{4 - A relação ciência, tecnologia e sociedade.}

O movimento ciência, tecnologia e sociedade (CTS) começa a se destacar na década de 1960, como resultado da percepção de que o desenvolvimento científico e tecnológico não promovia, necessariamente, o bem estar social. Isto é, o avanço da ciência e da tecnologia, conquanto produzissem benefícios para a humanidade, também resultavam em desastres ambientais, produção de armas, dentre outros males. Ele surge, então, como resposta à insatisfação com a concepção tradicional da ciência e da tecnologia (VON LINSINGEN, 2004). Trata-se de evidenciar a dimensão social e prática da ciência e da tecnologia, opondo-se à visão tradicional, na qual o 
desenvolvimento é um processo em que mais conhecimento científico determina linearmente mais tecnologia, o que conduz a mais desenvolvimento econômico, resultando em mais desenvolvimento social (bem estar).

Até a Segunda Guerra Mundial o mundo passava por um período de encantamento com as possibilidades de transformações que a ciência possibilitava. Esse encantamento configurou-se em um cientificismo, que contribuiu para a supervalorização da ciência por considerar que todos os problemas humanos poderiam ser resolvidos por ela e por disseminar uma ideia de ciência neutra (JAPIASSU, 1999; SANTOS e MORTIMER, 2002). Entretanto, os problemas ambientais enfrentados no pós-guerra e a conscientização de intelectuais quanto às questões éticas, a qualidade de vida da sociedade industrializada, a necessidade da participação popular nas decisões públicas e o medo decorrente dos excessos tecnológicos propiciaram as condições para o surgimento da proposta CTS (SANTOS e MORTIMER, 2002). A proposta CTS foi reforçada, ainda, por estudos na área da epistemologia, sociologia e filosofia da ciência que, por meio da análise de questões relativas aos aspectos econômicos e políticos da ciência, vinham desconstruindo o mito cientificista pela explicitação da não neutralidade científica e da incapacidade da ciência em resolver grandes questões éticas e sócio-políticas da humanidade (FOUREZ, 1995; JAPIASSU, 1999).

Assim, o movimento CTS surge na América do Norte e na Europa como crítica ao papel da ciência e da tecnologia na sociedade, originando-se de uma vertente ativista social, constituída por grupos ligados à reivindicação social (pacifistas, ecologistas, defensores de direitos civis etc.), e uma vertente acadêmica, orientada para o ensino e a pesquisa das questões públicas das quais participavam cientistas, engenheiros, sociólogos e humanistas. Desde seu início, esse movimento fundamenta-se em três proposições: a reflexão sobre a ciência e a tecnologia, promovendo uma visão contextualizada da atividade científica; a defesa da regulação social da ciência e da tecnologia por meio de mecanismos democráticos de tomada de decisão sobre questões de políticas científico-tecnológicas; e a introdução das discussões sobre as relações CTS na educação básica e superior (VON LINSINGEN, 2004).

Na perspectiva CTS, o desenvolvimento científico e tecnológico é visto como processo resultante de fatores culturais, políticos e econômicos, e também como condicionante da própria forma de vida, configurando-se como assunto de grande 
importância para o público. Nessa concepção, a avaliação e o controle social do desenvolvimento científico-tecnológico deve ser direito de cada um e de todos, o que implicaria a construção de bases educativas para a participação social e a criação de mecanismos para essa participação (VON LINSINGEN, 2004). Essa proposição se contrapõe ao "sistema de especialistas", segundo o qual os sujeitos relacionam-se socialmente baseando-se na confiança em especialistas (professores-pais, engenheirooperário, médico-paciente etc.). A sociedade é vista como "sociedade de risco global", na qual existem os riscos com consequências determinadas previamente (p. e. armas atômicas) e riscos marcados pela incerteza (p. e. transgênicos). No primeiro, o risco está associado à ciência, conquanto não se refira à incapacidade da ciência em produzir diagnósticos seguros. No segundo, porém, a ciência não é capaz de fornecer diagnósticos seguros, trilhando-se o caminho da probabilidade, do não determinismo. Na segunda situação não se resolve o problema consultando os especialistas (CAZELI e FRANCO, 2001).

Um dos conflitos resultantes dessa perspectiva é o aparente descrédito social no conhecimento dos especialistas, que antes detinham autoridade inquestionável em suas áreas. Se por um lado, a sociedade civil teria o direito de interferir diretamente nas questões tecnológicas, por outro lado especialistas em ciência e tecnologia argumentam que a comunidade não pode se manifestar em assunto de competência técnica por não dominar conhecimentos técnicos. Importante frisar que, nesta proposta, a participação do público não está focalizada no construto acadêmico, mas sim na decisão sobre o que escolher entre os construtos. Por exemplo, não é razoável que um leigo venha discutir com um químico orgânico se o mecanismo de uma reação segue por SN1 ou SN2, ou que para a síntese de um determinado composto deve-se seguir este ou aquele procedimento. Contudo parece razoável que o leigo possa opinar e escolher sobre a síntese de um composto $\mathrm{x}$ ao invés do y tendo em vista o custo de cada síntese para os cofres públicos e os impactos ambientais e sociais de cada um deles.

É possível identificar três objetivos gerais para a educação na proposta CTS, a saber, a aquisição de conhecimentos, a utilização de habilidades e o desenvolvimento de valores (BYBEE, 1987). Algumas das habilidades e conhecimentos envolvem a autoestima, a comunicação escrita e oral, o pensamento racional para solução de problemas, a tomada de decisão e a responsabilidade social, e valores tais como solidariedade, 
compromisso social e fraternidade (HOFSTEIN, AIKENHEAD e RIQUARTS, 1988). O currículo, nessa perspectiva, não se preocupa em mostrar as maravilhas da ciência e da tecnologia, mas sim em promover reflexões sobre esses campos do conhecimento humano de maneira que o cidadão possa agir, tomar decisões e compreender o que está em jogo no discurso dos especialistas (SANTOS e MORTIMER, 2002). Emerge desse currículo a concepção de ciência como uma tentativa de controlar o ambiente e as pessoas, estando ela diretamente relacionada à tecnologia e às questões sociais. Essa visão crítica da ciência busca desfazer o mito do cientificismo e, fundamentando-se em filósofos, sociólogos e epistemólogos da ciência, tais como Chalmers (1994), Latour e Woolgar (1997), Kuhn (2000), dentre outros, discute os limites da ciência e o significado das suas dimensões sociais e políticas, criticando a pseudociência, o método experimental, a neutralidade e a objetividade científica. Esses autores têm demonstrado que a ciência não se justifica somente por critérios racionais cognitivos, já que esses mesmos critérios são construídos socialmente.

Rosenthal (1989) ressalta que os aspectos da ciência a serem problematizados na proposta CTS são de natureza filosófica (aspectos éticos, impacto das descobertas científicas sobre a sociedade e a responsabilidade social dos cientistas etc.), sociológica (influências da ciência e tecnologia sobre a sociedade e vice-versa), histórica (influência da atividade científica e tecnológica na história da humanidade), política (interações com o sistema de governo e o uso político da ciência e tecnologia), econômica (contribuições para o desenvolvimento econômico, para o consumismo etc.) e humanística (aspectos estéticos, criativos e culturais da atividade científica). Percebe-se aqui uma acentuação do conhecimento da ciência "em relação", enquanto "em contato com”. Importante ressaltarmos que essa abordagem mais ampla da ciência se dá em detrimento de um maior conhecimento sobre a natureza da investigação científica (stricto senso) e do significado dos conceitos científicos.

Já a concepção de tecnologia a identifica como conjunto de atividades humanas, associadas a sistemas de símbolos, instrumentos e máquinas, com a finalidade de construir ou fabricar produtos utilizando-se de conhecimento sistematizado. Admite-se que a prática tecnológica é dividida em três aspectos centrais: aspecto técnico (conhecimentos, técnicas, ferramentas, máquinas, recursos humanos e materiais, matérias primas etc.); aspecto organizacional (atividade econômica e industrial, 
atividade profissional dos engenheiros, técnicos e operários, consumidores, sindicatos etc.) e aspecto cultural (objetivos, valores e códigos éticos, crenças sobre o progresso etc.) (SANTOS e MORTIMER 2002).

A concepção de sociedade traduz-se em um conjunto de pessoas (público geral e especialistas) em negociação com respeito às tomadas de decisões sobre problemas sociais relacionados à ciência e à tecnologia, sendo que os sujeitos sociais devem ser preparados para tomar decisões inteligentes, para isso devendo compreender a base científica da tecnologia e a base prática das tomadas de decisões. Quanto à abordagem dos conteúdos, o CTS propõe uma integração entre educação científica, tecnológica e social, na qual os conteúdos científicos e tecnológicos são estudados em meio às discussões de seus aspectos históricos, éticos, políticos e sócio-econômicos (SANTOS e MORTIMER 2002). A estrutura conceitual é composta por conceitos científicos e tecnológicos, processos de investigação e interações entre ciência, tecnologia e sociedade. A aquisição de conhecimentos científicos e tecnológicos enfatiza aspectos relacionados ao interesse pessoal, à preocupação cívica e às perspectivas culturais. Os processos de investigação científica e tecnológica propiciariam a participação ativa dos sujeitos na obtenção de informações, solução de problemas e tomada de decisão. A interação entre ciência, tecnologia e sociedade propiciaria o desenvolvimento de valores e ideias por meio de estudos de temas locais, políticas públicas e temas globais. Assim, o ensino dos conteúdos não se restringe à lógica interna das disciplinas científicas, ao contrário, valoriza a re-elaboração e articulação dos conteúdos a temas sociais relevantes (SCHNETZLER, 2002; SANTOS \& SCHNETZLER, 2003).

No estudo das referências acerca da proposta CTS frequentemente encontramos a utilização do termo CTSA, em especial em textos em espanhol ou em português, sendo que A refere-se a ambiente. Apesar de Bernardo, Viana e Fontoura (2007) considerarem que a proposta CTSA pode ser uma evolução da proposta CTS, com um destaque para o aspecto ambiente, percebeu-se na literatura aqui analisada que esses dois termos vêm sendo utilizados com a mesma finalidade, guardando entre si uma relação de igualdade e não de derivação. Ao que parece, na literatura consultada, considera-se que o aspecto ambiente já está contemplado dentro das relações CTS, uma vez que o impacto da ciência e da tecnologia sobre o ambiente foi um dos fatores que motivou o surgimento da proposta CTS. Ainda a respeito de possíveis variações do 
termo CTS, Ricardo (2007) atenta para o cuidado com uma desnecessária ampliação das entidades conceituais Ciência, Tecnologia e Sociedade visando a ênfase em um determinado aspecto. Por exemplo, na tentativa de destacar o aspecto ético surgiria o termo CTSAE, acarretando uma excessiva criação de termos.

\section{5 - Aprofundando as questões quanto à relação entre a ciência e a tecnologia}

Nessa pesquisa temos nos posicionado a favor do entendimento de que a alfabetização científica deve englobar, em si, o que alguns autores vêm chamando de alfabetização tecnológica. Nesse sentido, o texto que seguirá tem o intuito de explicitar melhor o que entendemos por tecnologia e sua relação com a ciência. Essa reflexão nos auxiliará na melhor percepção do objeto em estudo, uma peça de teatro que trata da tecnologia em aviação.

O início do esforço em diferenciar ciência e tecnologia poder ser localizado no princípio do século XIX. Nesse período o pensamento científico foi dividido em duas grandes correntes que resultaram no surgimento das faculdades de ciências (ciências fundamentais ou puras) e de outros empreendimentos científicos (ligados a práticas profissionais). As ciências chamadas puras tinham essa denominação devido à compreensão, à época, de que eram desprovidas dos contextos práticos, culturais e sociais que as haviam feito nascer. Já os outros "empreendimentos científicos" (cursos tecnológicos) resultaram no que vem sendo chamado de ciências aplicadas (orientadas por projetos e que guardam a memória dos interesses humanos que as estruturam). Desde esse período a tecnologia vem sendo considerada hierarquicamente inferior à ciência, sendo entendida como apenas uma aplicação prática desta com vistas a produzir artefatos com a intenção de melhorar a qualidade de vida ou para fabricar novos dispositivos (AULER \& DELIZOICOV, 2006). Acevedo (1996) acrescenta que, tradicionalmente, a técnica tem sido marginalizada pela filosofia em benefício da ciência, a ciência pura. O desinteresse filosófico pela técnica se deveria ao dogma cultural que privilegia o conhecimento teórico frente ao saber ligado às capacidades operatórias próprias das técnicas.

Fourez (1994), na análise que realiza sobre o tema, sinaliza que a diferenciação entre ciência e tecnologia tem recaído nos objetivos, nos métodos ou nos critérios para 
os resultados. Esse autor depreende da literatura especializada a proposição de que os objetivos da ciência se diferenciam dos objetivos da tecnologia por focalizarem o conhecimento em si, enquanto na tecnologia o foco é a ação. Nessa perspectiva a ciência se preocuparia em compreender os fenômenos e provar "verdades científicas", enquanto que a finalidade da tecnologia seria a de encontrar soluções para problemas concretos. No que se refere ao método, na ciência seriam aplicados tão somente os métodos da investigação científica, enquanto na tecnologia outros fatores também são importantes, tais como a estética, o gosto, a segurança, e a questão de saber se a tecnologia funciona. Por fim, os critérios exigidos para os resultados também seriam diferentes justamente por a atividade tecnológica ter que satisfazer a diversos aspectos externos (custo, gosto estético, eficácia, exigências do mercado e da cultura). Isto é, os resultados científicos não implicam necessariamente nos resultados tecnológicos. Também Gilbert (1995) propõe fatores para diferenciar ciência e tecnologia: as características próprias do conhecimento tecnológico, a atitude frente às publicações (artigos vs patentes) e o propósito dos laboratórios de investigação acadêmica e industrial. Esse mesmo autor ressalta que as diferenças entre os conhecimentos científicos e os conhecimentos tecnológicos recaem em diversos aspectos, dentre eles, a finalidade (explicação vs fabricação), o interesse (natural vs artificial), o método (analítico vs sintético), o procedimento (simplificação do fenômeno vs complexidade da necessidade formulada) e resultado (conhecimento generalizável vs objeto particular). Acevedo (1998), por sua vez, retoma as ideias de Mitcham ${ }^{1}$, ressaltando ainda que o critério de validade de uma teoria tecnológica não recai tanto em que seja verossímil, mas que, na prática, funcione e seja útil. Essa proposição traz implícita em si uma diferenciação entre racionalidade científica e racionalidade tecnológica e, por conseguinte, a concepção de que embora a ciência seja uma importante fonte de conhecimentos existem outras fontes em nossa cultura ocidental, por exemplo, a tecnologia.

Conquanto perceba o esforço em diferenciar ciência e tecnologia Fourez (1994) propõe similaridades. Ambas buscam inventar modelos que lhes permitam controlar processos concretos, seja no ambiente controlado dos laboratórios (no caso da ciência),

\footnotetext{
${ }^{1}$ MITCHAM, C. ¿Qué es la filosofía de la tecnología? Barcelona: Anthropos, 1989.
} 
seja na sociedade e seu contexto (no caso da tecnologia). Dessa maneira, tanto uma quanto outra tem como objetivo a busca de invenções-descobrimentos. E a "verdade" das ciências e das tecnologias se fundaria em sua ação controlada sobre o mundo. Quanto à impermeabilidade da ciência a fatores externos, o autor ressalta que os discursos e as representações científicas são levados por uma intencionalidade e uma finalidade humanas, jamais produzindo representações absolutas do mundo, antes sendo vinculadas a situações e projetos que nos fazem organizar o mundo de uma certa maneira. Nessa perspectiva a intencionalidade dos discursos científicos estaria apenas mais mascarada do que a dos discursos tecnológicos. Sendo assim, parece que não existe uma diferenciação tão profunda entre a ciência e a tecnologia.

Acevedo (1995) localiza na literatura duas concepções frequentes com respeito à tecnologia. A ideia mais comum é a de que ela está relacionada somente à capacidade e destreza para realizar atividades de produção de artefatos elaborados. O outro significado, mais amplo, permite situá-la em seu contexto social, levando em consideração questões sócio-tecnológicas derivadas de suas dimensões organizativa e cultural. Em outros trabalhos esse mesmo autor (ACEVEDO, 1996) discute sobre as deficiências do modelo linear e epistemologicamente hierárquico das relações entre ciência e tecnologia: tecnologia não é sinônimo de ciência aplicada. Ela não se limita a tomar emprestado as ideias da ciência para responder a determinadas necessidades humanas e alguns problemas sociais importantes. Ao contrário, a tecnologia tem desenvolvido seus próprios métodos, que perpetuam características específicas dos ofícios tradicionais, dos conhecimentos tácitos e das habilidades técnicas.

Por sua própria natureza, a tecnologia, como área do conhecimento, não pode ser considerada como conjunto limitado, já que se pode dizer que existem tantas tecnologias específicas quanto tipos de problemas a resolver (ACEVEDO, 1995). A tecnologia se nutre tanto de conhecimentos de outras áreas do saber como de sua própria experiência, construindo um conhecimento básico estruturado pela tensão entre as demandas de funcionalidade e das restrições impostas pelo entorno cultural e meio ambiente. Conhecimento este orientado para uma práxis concreta através da resolução de problemas e da tomada de decisões. Assim, a tecnologia é constituída pelos componentes científico-tecnológico (utiliza conceitos científicos, os quais são reelaborados e reconstruídos conceitualmente com a finalidade de adaptá-los ao 
contexto tecnológico, o mesmo se aplica ao método científico), histórico-cultural (relação entre as técnicas desenvolvidas pela humanidade e as mudanças que estas provocam na natureza, na cultura e nas condições de vida das pessoas), organizativosocial (tecnologia como fator que influencia nas formas de organização social), verbaliconográfico (formas de expressão e comunicação próprias da tecnologia: símbolos, vocabulário específico, etc.), técnico-metodológico (conjunto de capacidades e destrezas técnicas necessárias para manipular instrumentos e fabricar produtos tecnológicos).

De acordo com Acevedo (1998) o conhecimento tecnológico tem um caráter próprio que o diferencia, formal e substancialmente, do originado pela ciência básica. Nesse sentido, Fleming (1989) destaca os principais componentes que configuram o conhecimento tecnológico, são eles: os conceitos científicos, reelaborados de maneira a diminuir o nível de abstração e adaptá-los às necessidades e ao contexto de cada projeto tecnológico; conhecimento problemático, refere-se às questões decorrentes dos impactos sociais e ambientais de uma tecnologia, às dificuldades que aparecem ao se adotar uma inovação tecnológica, à transferência de uma tecnologia para os contextos culturais diversos etc.; teoria tecnológica, corpo de conhecimentos que utiliza métodos experimentais sistemáticos, supõe uma reflexão sobre a prática tecnológica, é uma mediadora entre a prática tecnológica e as teorias científicas; perícia técnica, procedimentos e técnicas específicas, com instrumentos e máquinas acompanhados de um conjunto de critérios pragmáticos baseados, sobretudo, em um conhecimento tácito quase impossível de codificar.

Conquanto diversos autores tenham empregado esforço no sentido de definir a tecnologia e elucidar sua estrutura e dinâmica, Takahashi (2009) considera que ainda não se tem clareza do mecanismo básico de desenvolvimento do conhecimento tecnológico. Não há uma compreensão generalizável da dinâmica em que o conhecimento tecnológico é elaborado e reelaborado, bem como da maneira com que os artefatos tecnológicos emergem desse conhecimento. Na perspectiva desse autor, a filosofia da tecnologia caminha para o entendimento de que o conhecimento tecnológico seria essencialmente assistemático e não susceptível de ser formalizado. Contudo Takahashi op. cit. define um tipo de conhecimento, denominado de conhecimento tecnológico do tipo científico, o qual: 
- É compatível com a ciência contemporânea e controlável pelo método científico;

- É empregado para controlar, transformar ou criar coisas ou processos, naturais ou sociais. [...]

- Possui uma estrutura cujo núcleo é constituído de formulações teóricas próprias;

- Apresenta uma dinâmica que se manifesta na forma de sucessivas reconstruções de tal núcleo, motivadas pela constatação de inadequações entre predições teóricas e observações empíricas. (TAKAHASHI, 2009, p. 82).

Depreende-se do exposto que a relação entre a ciência e a tecnologia é bastante difusa, sendo difícil estabelecer limites muito rígidos entre ambas. Contudo, é possível perceber o esforço em delinear semelhanças e diferenças entre esses campos. Nessa pesquisa consideramos que a consciência dessa complexidade é um aspecto importante da alfabetização científica, uma vez que por meio dessa conscientização seria possível depurar concepções equivocadas e comumente veiculadas de que a tecnologia emana diretamente da ciência.

Há que se considerar também que um melhor entendimento da ciência em si passa pelo processo de comparação entre esse empreendimento e outros semelhantes, tais como a tecnologia. Assim, o estudo da natureza da ciência, acrescido do estudo da natureza da tecnologia, levaria ao melhor entendimento de ambos os campos e resultaria em um sujeito mais bem alfabetizado cientificamente.

\section{6 - Os museus e centros de ciências e a alfabetização científica}

A educação em ciências, na perspectiva da alfabetização científica, exige um processo contínuo, ao longo de toda a vida, e que dificilmente se encerra no universo da escola. Cada vez mais a sociedade entende a educação como processo que não acontece somente no espaço da escola, além de não se limitar ao período de formação escolar (CAZELLI, GOUVÊA e FRANCO, 2001). Isso, entretanto, não reduz o papel fundamental da escola, mas amplia a responsabilidade do Estado em fornecer meios de aprofundamento do conhecimento, pois não se pode entender o desenvolvimento sem 
que o cidadão tenha várias possibilidades e/ou oportunidades de atualizar seus conhecimentos, sua cultura.

Gaspar (1992) argumenta que uma parte substancial da alfabetização científica é realizada pela educação escolar. É a escola a responsável por auxiliar os educandos na construção de sua alfabetização, pela aprendizagem das primeiras operações aritméticas e dos primeiros conceitos científicos. Entretanto, os currículos, programas e horários, e o compromisso com uma determinada formação impedem o acompanhamento do desenvolvimento científico e tecnológico. Isso se dá porque a escola tem como matériaprima o conhecimento consolidado e sistematizado e isso retarda a atualização. Diversos autores têm discutido e demonstrado que a inserção de um novo conhecimento na escola passa por um processo complexo de transposição no qual o conhecimento a ser transposto tem que atender a diversas características tais como a consensualidade, atualidade, operacionalidade, criatividade didática e terapêutica. Além disso, o novo conhecimento deve modernizar o saber escolar, atualizar o saber a ensinar e articular o saber novo com o antigo. Também deve ser possível transformar esse novo conhecimento em exercícios e problemas (CHEVALLARD, 1998; MARANDINO ET ALL, 2004; BROCKINGTON e PIETROCOLA; 2005; BATISTETI, ARAUJO e CALUZI, 2010; MILICIC, UTGES e SALINAS, 2008; KIOURANIS, SOUSA e FILHO, 2010). Dessa maneira, conquanto se constate a essencialidade da educação escolar no processo de alfabetização científica, percebe-se que, isolada, ela não é suficiente.

Assim, atualmente há o reconhecimento de que a educação fora da escola é importante para a formação dos sujeitos, tanto no intuito de complementar quanto no de ampliar a educação escolar. Também é uma perspectiva comum a de que os Museus e Centros de Ciências (MCC) se configuram como importante espaço em que essa educação não escolar pode ocorrer. Nesse sentido, Cazelli e Franco (2001) ressaltam a importância do fortalecimento de instâncias não escolares de educação devido ao contexto mundial de transformações rápidas, de modernização da sociedade e de redefinição do tempo e do espaço social. Também Coutinho-Silva et al (2005) reafirmam que os MCC se apresentam como espaço educativo complementar à educação escolar. Constantin (2001) sinaliza que a alfabetização científica deve ser contínua e 
realizada por variadas frentes, sejam elas a comunicação de massa, as instâncias formais de educação e os espaços de educação não formal.

Isto posto, os MCC despontam como espaços contribuintes para a popularização da ciência, aprendizagem e, por conseguinte, da alfabetização científica. Sabbatini (2003) fortalece essa perspectiva ao ressaltar que os MCC se destacam na difusão da cultura científica para toda a sociedade por possibilitar a conexão entre avanços e questões referentes à ciência e a tecnologia e os interesses do cidadão comum. Entretanto, não se deve perder de vista que os MCC têm a tarefa primeira de divulgar a ciência, o que não implica, necessariamente, em ensinar ciências (CONSTANTIN, 2001), em um sentido escolar. A divulgação teria como objetivo ser um instrumento motivador, aguçar a curiosidade, sendo complementar ao ensino formal, sistemático.

Com respeito à discussão sobre ao papel educador dos MCC, Cazelli (2005) relata que esses espaços têm sofrido mudanças nas últimas décadas, cada vez mais deixam de ser armazéns de objetos para se tornarem lugares de aprendizagem, em um movimento de olhar para as coleções e para o público. No decorrer do século XX os museus foram sendo re-configurados, com o papel pedagógico de cooperação com o ensino formal sendo acentuado cada vez mais. Essa nova configuração vinha ao encontro da mudança da prática e do papel social dos museus, que ganhou força a partir da década de 1960, e que tinha como propósito a difusão de princípios científicos e tecnológicos visando induzir os jovens às carreiras científicas. Essas novas perspectivas foram ao encontro dos esforços em reduzir os níveis de "analfabetismo científico", sendo os MCCs considerados fontes importantes de aprendizagem fora do âmbito escolar, que proporcionaria uma educação continuada em ciências após o término da educação formal.

Embora os MCC tenham assumido finalidades educacionais diversos autores têm demonstrado que esses espaços possuem características próprias que os diferenciam da escola. Por exemplo, para Gouvêa e Leal (2001) a escola estabelece rotinas para aquisição dos saberes, há um tempo determinado para cada passo do trabalho escolar. $\mathrm{O}$ que se aprende, como se aprende e o tempo para aprender são determinados pela rotina pré-estabelecida. No museu a estrutura já não é tão rígida como explica Allard et all (1996 apud MARANDINO, 2001). Segundo esses autores na escola o objetivo é instruir, os sujeitos são cativos e o público é estável, agrupado em turmas em função da 
idade ou da formação, estão submetidos a um programa específico e as atividades são fundadas no livro e na palavra. Por outro lado, no museu o objetivo é recolher, conservar, estudar e expor, os sujeitos são livres e passageiros, os grupos são heterogêneos (idade, formação etc.), as atividades pedagógicas são organizadas em função da coleção e planejadas para situações individuais ou pequenos grupos, com duração de 1 ou 2 horas, sendo fundada no objeto.

Marandino (2001) contribui para essa discussão sinalizando que o museu se diferencia da escola não só quanto a seleção e amplitude dos conteúdos abordados, como também em relação a forma de apresentação deles. Através de variados estímulos oferecidos ao público o processo de aquisição do conhecimento se torna particular nesses espaços. Essa mesma autora propõe um Modelo para Estudo das Relações Pedagógicas no Museu (MARANDINO, 2005) já que nele o discurso expositivo é resultante de articulações entre o saber do senso comum (modelos do senso comum sobre conceitos e fenômenos científicos), o saber sábio (paradigmas hegemônicos das áreas científicas), o saber museológico (reflexões do campo da museologia), o saber da comunicação (técnicas de design, estudos de linguagem etc.), o saber da educação (aspectos de aprendizagem, dimensões do processo educacional etc.) e outros saberes (relativos aos saberes práticos, profissionais, técnicos). Nessa perspectiva, a educação em museus parece assumir um nível de complexidade diferenciada por estar compromissada com saberes que não estão em jogo no contexto escolar.

Valente (2005) sinaliza a proficuidade do museu enquanto local de alfabetização científica. Para essa autora, os MCC são propícios à percepção da ciência e da tecnologia enquanto realizações da cultura humana, uma vez que através da exposição dos instrumentos científicos e tecnológicos pode-se facilitar a introdução da relação entre a ciência e a técnica, a abordagem de aspectos de ordem histórica, metodológica e cultural, o entendimento da ciência como conhecimento e atividade, e a tensão entre ciência e técnica. Esse estilo de abordagem contribui para o entendimento do caráter hipotético do ensaio e erro da pesquisa, para a compreensão de que o conhecimento científico e tecnológico é alcançado após a superação de preconceitos e obstáculos, por meio de discussões. Esses espaços se configurariam, então, como instâncias em que se desenvolvem níveis complexos da alfabetização científica pela articulação entre o objeto, a história e a cultura científica. 
Cazelli (1992), em sua dissertação feita no início dos anos 1990, já anunciava a relação entre as exposições e as perspectivas da alfabetização científica:

Por exemplo, uma exposição sobre mortalidade infantil ou sobre ecologia poderá causar algum impacto sobre a alfabetização científica prática e cívica (forma de alfabetização científica propostas por Shen, apresentadas na introdução). Já uma exposição sobre dinossauros terá pouco impacto nessas duas primeiras formas de alfabetização, mas é possível que contribua para a alfabetização científica e cultural. [...] Outro exemplo que ilustra essa preocupação em relacionar o assunto de uma exposição e com alguns componentes do conceito de alfabetização científica é a exposição permanente do Museum of Science and Industry de Chicago intitulada de Inquiry. Ela foi criada especialmente com o objetivo de levar ao conhecimento do público os processos da ciência, em vez de enfatizar seus produtos. Dentro desse objetivo central está o de desmitificar e, ao mesmo tempo, desbancar alguns estereótipos comuns sobre a ciência e os cientistas (CAZELLI, 1992, p. 55-56).

Considerando a literatura consultada, percebe-se que os MCC possuem grande potencial visando à educação em ciências. Ao que parece, esses espaços podem contemplar diferentes perspectivas da alfabetização científica. Nessa pesquisa propomos um olhar mais próximo dessa relação e da maneira com que ela acontece nas atividades museais. Sabe-se que, se por um lado, a exposição é uma das principais formas de relação dos museus como seus públicos, também é comum o desenvolvimento de ações educacionais variadas como finalidades distintas para alcançar a diversidade de visitantes. Seria a exposição a única atividade museal capaz de ser organizada para abordar a perspectiva da alfabetização científica? Quais outras atividades museais poderiam servir a esse mesmo propósito? A ideia de alfabetização científica está presente no momento da construção das atividades? Esses são alguns dos questionamentos que compõem nosso plano de fundo.

Uma atividade que vêm ganhando vulto nos MCC brasileiros é o teatro. Discutiremos o quanto essa atividade vem crescendo dentro dos MCC brasileiros: Por que houve essa apropriação? O teatro dentro dos MCC potencializam quais aspectos da AC? O que é contemplado da alfabetização científica no teatro enquanto atividade museal? Nesta pesquisa procuraremos elucidar a relação entre a alfabetização científica e o teatro realizado dentro (e pelos) MCC. Nossa preocupação passará por caracterizar essa atividade e por entender como ela pode promover ao público visitante o 
desenvolvimento da alfabetização científica, seja na relação com as outras atividades museais, seja como atividade independente.

Assim, o objetivo geral dessa pesquisa é analisar articulações estabelecidas entre o Teatro nos Museus e Centros de Ciência e a alfabetização científica, no intuito de desvelar como peças teatrais do projeto Núcleo de Artes Cênicas da Estação Ciência da USP poderiam favorecer a alfabetização científica. Dessa maneira, o questionamento central a que nos propomos responder é: Como o teatro realizado pelos Museus e Centros de Ciências dialoga com a perspectiva da alfabetização científica? A partir dessa questão, temos como objetivos específicos:

i. Explicitar como museus e centros de ciências se apropriaram do Teatro.

ii. Delinear as características do Teatro enquanto ação de museus e centros de ciências.

iii. Analisar como as encenações teatrais realizadas em centros e museus de ciências se articulam com a perspectiva da alfabetização científica.

Com isso pretende-se construir conhecimentos sobre o teatro com temática científica enquanto atividade museal, sobre as limitações e possibilidades da articulação entre teatro, museu e alfabetização científica, bem como produzir dados para um diálogo entre a realidade dessa prática no Brasil e em outros países, fomentando, assim, a pesquisa nesse campo.

\section{7 - Categorias de análise}

Considerando a literatura consultada, é possível perceber aspectos em comum nas proposições dos diversos autores quanto ao que seja a alfabetização científica e quais suas principais características. Esses aspectos podem ser reunidos em três dimensões, quais sejam, natureza da ciência, conhecimentos e conceitos básicos da ciência e relação entre ciência, tecnologia, sociedade e meio ambiente.

A dimensão natureza da ciência congrega as ideias com respeito à necessidade de se conhecer a cultura científica, isto é, ao entendimento da própria natureza da ciência. Isso se traduz no conhecimento dos processos da ciência (CAZELLI, 1992), contemplando como uma investigação científica acontece (MILLER, 1983; SHAMOS, 1995), a história da ciência (BYBEE; 1995), os fatos e a filosofia do conhecimento científico (HAZEN E TREFIL; 1995), a ética e a política científica (PELLA et all, 
1966; SASSERON E CARVALHO, 2011), a construção dos conhecimentos científicos e seus decorrentes avanços e prejuízos (KRASILCHIK E MARANDINO, 2001). Também aqui se enquadra a conscientização de que os processos científicos envolvem o exame minucioso, a inferência (dedução pelo raciocínio) e o trabalho com hipóteses e testes, o reconhecimento da mutabilidade e temporalidade dos conceitos e teorias científicas e a percepção da maneira pela qual tais estruturas são continuamente aperfeiçoadas ou aprimoradas, bem como de que os conceitos científicos são inventados ou criados por atos da inteligência e da imaginação humana (ARONS, 1983).

Importante ressaltar que a dimensão natureza da ciência congrega também proposições que promovem o reconhecimento da ciência como um construto humano (SHEN; 1975), um produto da curiosidade do cientista (HURD, 1998). E, nesse aspecto, contempla o reconhecimento da ciência como resultado dos esforços de pessoas (cientistas), com suas vontades, seus desejos, seus interesses, seus sonhos etc. Nesse sentido, localizamos aqui o estímulo à liberdade intelectual (PELLA at all, 1966), uma vez que o conhecimento dos diversos aspectos da natureza da ciência forneceria aos sujeitos instrumentação cognitiva para pensar, pesquisar e analisar o mundo.

A dimensão conhecimentos e conceitos básicos da ciência reúne as proposições com respeito à importância de se adquirir conhecimentos científicos básicos. Envolve a apreensão de conceitos chave em ciências e a utilização destes para se comunicar, ler e construir novos significados (PELLA at all, 1966; MILLER, 1983, SHAMOS, 1995, ARONS, 1983, CAZELLI, 1992), bem como para resolver problemas básicos da vida cotidiana, para a tomada de decisões, para a participação em debates públicos sobre questões de ciência e tecnologia e para a exigência de condições dignas de existência (SHEN, 1975; HAZEN e TREFIL, 1995, HURD, 1998, FOUREZ, 1994). Essa dimensão engloba a aquisição de vocabulário, informações, fatos, conceitos e ideias da ciência (BYBEE, 1995; HAZEN e TREFILL, 1995)

$\mathrm{Na}$ formulação dessas duas primeiras dimensões é perceptível o prevalecimento da ciência, comumente dita pura, sobre a tecnologia. Conquanto a tecnologia tenha sido citada, em especial na segunda dimensão, verifica-se que ela ocupa um lugar menor. Acreditamos, então, que essas dimensões são suficientes para descrever e/ou analisar iniciativas que se referem ao conhecimento preponderantemente científico. Porém, são deficientes quando se assume a concepção de alfabetização científica que adotamos 
nessa pesquisa, qual seja, uma alfabetização científica que contemple o conhecimento da ciência e o conhecimento da tecnologia, e este último não sendo um mero apêndice do primeiro. Quando o objeto em análise é mais fortemente marcado pela presença da tecnologia do que pela ciência as duas primeiras dimensões se mostram, na prática, pouco eficientes. $\mathrm{O}$ que sugere a necessidade de uma adequação, melhor dizendo, uma ampliação.

Assim, consideramos que para o entendimento da alfabetização científica da maneira que aqui adotamos, tão importante quanto o conhecimento da natureza da ciência é também o conhecimento da natureza da tecnologia. Denominaremos a dimensão que contempla essa proposição de natureza da ciência e da tecnologia. Essa dimensão contempla proposições já descritas na dimensão natureza da ciência, contudo ampliando os aspectos analisados também para o campo da tecnologia. Dessa forma, engloba os procedimentos e os conhecimentos referentes às estruturas da ciência e da tecnologia, seus elementos, seus produtos e os fatores (éticos, políticos, culturais, econômicos etc.) que influenciam as práticas de ambas, bem como a relação entre ciência e tecnologia strictu sensu, isto é, de maneira a vislumbrar semelhanças e diferenciações, favorecendo a percepção da complexidade existente entre esses dois campos, ora tendendo para a independência ora tendendo para a dependência. Contempla também o reconhecimento de que ambas as práticas são resultantes da curiosidade, da imaginação e da inventividade humana.

Na continuidade dos argumentos já apresentados, consideramos importante uma ampliação também quanto aos conhecimentos e conceitos em si. No lugar de se pensar em aquisição de conhecimentos e conceitos científicos básicos dever-se-ia pensar em conhecimentos e conceitos básicos da ciência e da tecnologia. Essa dimensão amplia também para o campo tecnológico a aquisição de conhecimentos e conceitos básicos e a aplicação destes na tomada de decisões e resolução de problemas, nos moldes já descritos, com relação à ciência. Aqui também se deve contemplar um tópico importante a ser problematizado, qual seja, a relação entre o conhecimento científico e o conhecimento tecnológico. Aqui surge a necessidade de explicitar a relação difusa existente entre o conhecimento científico e o conhecimento tecnológico, que algumas vezes guardam entre si uma relação de derivação e, outras, de autonomia. 
Por fim, identificamos a dimensão relação entre ciência, tecnologia, sociedade

e meio ambiente. Essa agrupa proposições com respeito ao conhecimento das relações entre as ciências, as tecnologias e as humanidades, problematizando os avanços, consequências e impactos da ciência e da tecnologia para a vida em sociedade e o meio ambiente (PELLA at all, 1966; HAZEN E TREFIL, 1991; CAZELLI, 1992; SHAMOS, 1995; MILLER, 1983; SHEN, 1975; Fourez, 1994; BYBEE, 1995; LEAL E SOUZA, 1997; KRASILCHIK E MARANDINO, 2001). Também aqui se encontra as proposições referentes à utilização da ciência e da tecnologia na vida do homem, provocando mudanças na democracia, no progresso social e nas necessidades de adaptação do ser humano (ARONS, 1983). Essa dimensão contempla o reconhecimento dos pesquisadores como produtores de conhecimentos científicos e dos cidadãos como usuários desse conhecimento e a identificação das situações em que a relação de causa e efeito não pode ser construída (HURD, 1998).

Isto posto, analisaremos em que medida o objeto desta pesquisa contempla as proposições da alfabetização científica por meio das dimensões acima descritas, quais sejam:

(i) Natureza da ciência e da tecnologia.

(ii) Conhecimentos e conceitos básicos da ciência e da tecnologia.

(iii) Relação entre ciência, tecnologia, sociedade e meio ambiente.

Um fator que nos chama atenção, e que propõe outro aspecto a ser analisado, está relacionado com o fato de o espetáculo teatral em análise estar inserido em um museu de ciências. Isso sugere a hipótese de que essa atividade poderia atuar em conjunto com outras ações museais no sentido de se alcançar a alfabetização científica. Nesse contexto, o que seria atribuição da peça de teatro e o que seria atribuição das demais ações museais? Dessa maneira nos preocuparemos, também, em elucidar (iv) a relação entre o espetáculo teatral e outras ações museais, em especial a exposição, no intuito de analisar como a instituição museu pode contribuir para o processo de alfabetização científica de seus visitantes. 
O TEATRO EM Museus E Centros de Ciência 
Nesse capítulo analisaremos o contexto que possibilitou a incorporação do teatro no rol de atividades de Museus e Centros de Ciências (MCC). A hipótese que defenderemos é a de que a evolução dos objetivos e finalidades dos MCC levou à necessidade de se criar novas formas de interagir com o público visitante, de maneira a favorecer uma maior mobilização da atenção e a despertar o interesse. O argumento que será desenvolvido fundamenta-se na ideia de que, por um lado, a incorporação da vocação educacional pelos MCC favoreceu a busca por estratégias de ensino e de aprendizagem mais sedutoras e, por outro lado, a vocação de divulgação da ciência exigiu estratégias de comunicação em massa que informassem, divertissem e sensibilizassem o espectador para as questões científicas. Assim, o teatro mostrou-se como atividade possível e desejável em MCC visando atender às demandas sinalizadas.

Em seguida, discutiremos sobre as ações que têm sido denominadas de teatro científico, buscando explicitar as definições que diversos autores propõem para essas ações e as problemáticas dessa prática. Construiremos uma crítica ao termo teatro 
científico e proporemos a utilização do termo teatro com temática científica como uma alternativa mais abrangente e mais profícua, tendo em vista a diversidade das práticas denominadas por esse termo e o crescente campo de pesquisa das Artes Cênicas.

\section{1 - Entre a divulgação científica e a educação}

Popularização, comunicação, difusão, disseminação divulgação, entre outros, são termos utilizados para definir atividades que têm como finalidade possibilitar o conhecimento sobre ciências e tecnologia. Acerca da problemática conceitual nesse campo, Massarani (1998) e Loureiro (2003) argumentam que termos como difusão, disseminação e divulgação científica são, frequentemente, utilizados sem rigor conceitual e propõem o entendimento de que difusão científica é todo processo ou recurso utilizado para a veiculação de informações científicas e tecnológicas. De acordo com o público a que se destina e a linguagem empregada, subdivide-se em disseminação científica intrapares e extrapares. A primeira compreende o fluxo informacional entre especialistas de uma mesma área do saber e áreas afins, caracterizando-se por abarcar um público especializado, conteúdo específico e código específico. A segunda está voltada à propagação da informação visando especialistas de outras áreas do conhecimento. O público-alvo é ainda formado por especialistas, embora de áreas diferenciadas, e seu conteúdo apresenta interesse para campos heterogêneos. Já a divulgação científica (vulgarização, popularização ou comunicação pública) é voltada para a circulação de informação em ciência e tecnologia para o público em geral, implica em traduzir fatos e princípios da ciência em linguagem acessível ao público geral. De acordo com Massarani (1998) e Ribeiro (2007), no Brasil, durante o século XIX e início do XX, a designação vulgarização científica (influência francesa) era bastante utilizada; já em meados do século XX, o termo popularização (influência inglesa) também era mencionado com frequência. Atualmente, a designação divulgação científica tem sido hegemônica.

Os motivos para a realização da divulgação científica têm variado ao longo dos séculos. Massarani (1998) argumenta que:

No século XVIII as maravilhas da ciência eram exibidas como provas da existência de Deus, posteriormente, com o iluminismo, tornou-se importante difundir os conhecimentos necessários ao progresso e à afirmação da razão. No século XIX, a ciência, além de 
se aliar mais fortemente às artes industriais, adquiriu caráter político mais explícito ao se tornar símbolo do progresso e instrumento para a liberação social. Correntes ideológicas fortes, como o positivismo e o marxismo, viram nela um ponto de apoio fundamental para suas visões de mundo e para a evolução da humanidade. No século $\mathrm{XX}$, estreitou-se o vínculo entre a ciência e a tecnologia e o tecido econômico-industrial-militar, especialmente após a Segunda Guerra Mundial; o impacto da ciência e da tecnologia na vida cotidiana do cidadão aumentou muito. Com a aliança poderosa entre o saber e o poder e com os novos meios de comunicação de massa, a divulgação científica se ampliou e adquiriu novos contornos (MASSARANI, 1998, p. 31).

Percebe-se pelo relato que a motivação para a divulgação científica segue tendências sociais e econômicas. Em certa medida, com a ciência e seus argumentos sendo um veículo para legitimação de ideias e de concepções de mundo. Fica, então, um questionamento sobre o quanto a divulgação científica tem, de fato, se proposto a levar conhecimento científico para a população em geral e o quanto ela se destina à manutenção das estruturas sociais e econômicas. Nesse sentido, Díaz (1999) sinaliza que os motivos para se divulgar a ciência são diversos, variando desde o mais altruísta, com finalidades de promover a educação científica da população, à manutenção do status sócio econômico e do financiamento dos envolvidos na atividade científica.

Fayard (1999) descreve como os espaços de divulgação da ciência, tal como museus e centros de ciência, contribuíram para a popularização da investigação e da tecnologia, favorecendo o estabelecimento de um diálogo entre ciência e sociedade. Em um movimento passou que se modificou do privilégio ao conteúdo, ao emissor, para a valorização da recepção. A problemática foi se modificando da perspectiva da quantidade de conhecimentos para a capacidade de mobilizar as informações úteis em um momento adequado e numa lógica de fluxo.

Novas maneiras de se conceber a divulgação da ciência também acompanharam a evolução dos museus e centros de ciências. Lewenstein (2003) propõe quatro modelos para descrever atividades de comunicação pública realizadas em museus de ciência, no jornalismo científico, ou em programas sobre ciências. São eles modelo de déficit, 
contextual, participação pública e conhecimento leigo. O modelo de déficit considera que existe um déficit do conhecimento que o público possui em relação aos cientistas. Nele, a comunicação segue o fluxo único cientistas (emissores) $\square$ público (receptores), pressupõe-se que os primeiros são os detentores dos conhecimentos sobre ciência e tecnologia e, por isso, devem suprir as necessidades em relação aos conhecimentos científicos. Todo o processo de comunicação focaliza a informação e a produção do conhecimento e não a relação entre cientistas e não cientistas. O modelo de déficit tem recebido críticas por desconsiderar o conhecimento comum, cultural, e por apresentar a comunicação de maneira descontextualizada quanto ao público. Essa perspectiva de divulgação científica estava bastante presente no início da década de 1950 e recebeu diversas críticas por considerar o público como sem conhecimentos e por não contextualizar os conhecimentos científicos. Massarani (1998) tem defendido que essa concepção de divulgação científica tende a contribuir para formação de sujeitos incapazes de avaliar as descobertas científicas, que acreditam piamente nos cientistas e que se escandalizam quando algo "não funciona direito".

Decorrendo das críticas ao modelo de déficit surge o modelo contextual, que valoriza o conhecimento prévio do indivíduo, suas experiências culturais e as circunstâncias pessoais. Nesse modelo considera-se que a compreensão é facilitada quando os conhecimentos científicos e tecnológicos são contextualizados com o entorno dos sujeitos. Entretanto Lewenstein (2003) sinaliza que esse modelo seria uma versão sofisticada do modelo de déficit, pois ainda que se considere as condições de recepção da informação, as respostas do público são ignoradas, objetivando, portanto, formas de facilitar a aquisição da informação e não sua compreensão.

$\mathrm{O}$ modelo de conhecimento leigo surge no século $\mathrm{XX}$, quando o fortalecimento da sociedade democrática exigiu novas formas de pensar e aplicar modelos mais democráticos de comunicação pública da ciência. Esse modelo propõe a valorização do conhecimento local ou tradicional, sendo que ele pode ter a mesma relevância que os conhecimentos científicos na solução de problemas. Nesse momento histórico, há o questionamento sobre os cientistas enquanto detentores do conhecimento verdadeiro, gerando críticas à sociedade científica baseadas na relevância dada a valores e crenças (DURANT, 1999). 
Nesse mesmo contexto de mudanças estruturais da sociedade democrática, ainda no século XX, é que aparece o modelo de participação pública. O qual situa seu foco na forma com que o indivíduo se apropria do conhecimento científico, integra-o a outros saberes e o utiliza na tomada de decisões (NAVAS, 2008). De acordo com Durant (1999), neste modelo, público e cientistas participam das discussões nas mesmas condições em fóruns, debates e conferências. Há valorização do diálogo entre cientistas e não-cientistas e do conhecimento sobre a dimensão cultural em que a ciência está inserida. As críticas a esse modelo referem-se à relevância dada aos processos da ciência em detrimento dos conteúdos e à orientação do modelo estar na elaboração de políticas de ciência e de tecnologia e não na compreensão pública da ciência (NAVAS, 2008). É importante sinalizar que apesar da literatura demonstrar uma linha evolutiva dos museus e centros de ciências é perceptível que, atualmente, as diversas concepções de divulgação científica coexistem no campo da prática.

$\mathrm{Na}$ leitura que fazemos das diferentes concepções de comunicação pública da ciência, percebemos um movimento rumo a níveis cada vez mais complexos de alfabetização científica, esta entendida como a aquisição de conhecimentos científicos e tecnológicos necessários para o desenvolvimento da vida diária, para ajudar a resolver os problemas e as necessidades de saúde e sobrevivência básica, conscientizar-se e posicionar-se politicamente diante das complexas relações entre a ciência, a tecnologia e a sociedade.

Inicialmente a perspectiva do modelo de déficit se concentrava no nível mais primário da alfabetização científica, qual seja a abordagem prioritariamente conceitual, deixando de incorporar a instrumentalização dos conceitos científicos para um diálogo mais crítico com mundo. Posteriormente, no modelo contextual há uma maior aproximação com a ideologia da alfabetização científica, no sentido de possibilitar aos sujeitos a reflexão sobre sua própria realidade, já que o reconhecimento de que o conhecimento prévio dos visitantes influencia na maneira com que a informação sobre ciência é assimilada leva à importância da contextualização dos conhecimentos científicos e tecnológicos nas propostas de comunicação da ciência. No modelo de conhecimento leigo, por sua vez, há indícios de uma melhor adequação metodológica com a proposta de alfabetização científica, pois esse modelo prevê a valorização do conhecimento local, ou tradicional, no processo de resolução de problemas envolvendo 
a ciência e a tecnologia. Ou seja, o conhecimento comum não só é reconhecido como influente sobre a construção do conhecimento científico e tecnológico, mas assume o status de conhecimento relevante a ser contemplado nas discussões. Vemos aqui um processo que tende a favorecer uma contextualização mais significativa dos conceitos científicos e tecnológicos e a possibilitar aos sujeitos uma participação pessoal e coletiva na construção de suas concepções de mundo.

Por fim, o modelo de participação pública favorece níveis mais complexos de alfabetização científica. Uma vez na posição de igualdade com os cientistas, em fóruns de discussão, os sujeitos teriam que ter a compreensão básica dos processos e conceitos científicos e tecnológicos, conscientizar-se dos impactos sociais, ambientais e culturais e exercer seu papel de cidadãos, participando das instâncias democráticas decisórias para defender seu ponto de vista. Todo esse movimento envolve o processo complexo de apreensão da ciência e tecnologia, para além de seus conceitos, e a utilização desses conhecimentos para a leitura do mundo e modificação da realidade. Consideramos que um sujeito com essa postura seria o mais bem alfabetizado cientificamente.

Como possibilitar ao público visitante dos MCC a abordagem de assuntos da ciência e da tecnologia de maneira a estimular essa nova postura? Quais ações poderiam possibilitar que os visitantes vivenciassem debates? Ou que fossem colocados em situações em que seja necessária a defesa de seus pontos de vista? Esses questionamentos nos direcionam para estratégias que favoreçam a compreensão da ciência e da tecnologia para além da abordagem conceitual, abarcando também os aspectos sociais, culturais e filosóficos. Ao mesmo tempo, essas estratégias deveriam possibilitar o conhecimento da dinâmica das argumentações em uma situação de debate, bem como das características de um argumento de qualidade. Além disso, seria interessante que esse tipo de estratégia possibilitasse a vivência/experiência da situação de debate, mesmo que no campo da simulação. Deixaremos de lado, por enquanto, a delimitação da estratégia em si para elucidarmos outra perspectiva que também culmina com a necessidade de que ela exista dentro dos MCC.

Ao mesmo tempo em que se percebe a evolução dos MCC no que se refere à concepção de divulgação científica, alguns autores demonstram outra linha evolutiva, construída sobre a ideia de museu enquanto espaço de educação não formal, na qual 
também se constata a finalidade de incentivar a participação do visitante e mobilizar sua atenção.

O termo não formal tem sido utilizado para nomear atividades educacionais diferenciadas das atividades que ocorrem nas escolas. De acordo com Smith (2001) e Fávero (2007) a terminologia formal/não formal/informal tem origem anglo-saxônica e foi cunhada nas décadas de 1960/1970, em decorrência da lenta adaptação da escola às mudanças sócio-econômicas em curso. A crise da educação formal exigiu um replanejamento educacional e a valorização de atividades e experiências não-escolares referentes à formação profissional e à cultura em geral. Era o início da preocupação com uma educação permanente, para toda vida, e que abrangesse sujeitos de idades diferenciadas e em momentos diferenciados da vida. Conquanto os termos educação formal, não formal e informal tenham surgido há bastante tempo, ainda hoje não se tem um diferenciação muito clara entre seus significados. Por exemplo, Marandino et al (2004) demonstram como a distinção entre esses termos não é clara mesmo entre sujeitos diretamente relacionados com atividades de divulgação científica e educação formal.

De acordo com Cazelli (2000) autores de língua inglesa usam os termos informal science education e informal science learning para todo tipo de educação em ciências fora da escola. Já os de língua portuguesa subdividem a educação em ciências fora da escola em dois subgrupos: educação não formal e educação informal. Smith (2001), em sua revisão sobre a temática educação formal e não formal, relata que na literatura por ele analisada as diferenças entre essas formas de educação recaem em critérios administrativos (hierarquização), propósitos, organização temporal, conteúdos, forma de apresentação e controle.

Uma proposta de definição é feita por Maarschalk (1988): este caracteriza a educação formal como altamente estruturada, sendo desenvolvida em instituições próprias (escolas e universidades) em acordo com um programa pré-determinado (currículo), o qual todos os estudantes da instituição devem seguir. A educação nãoformal é a que acontece fora da esfera escolar, sendo promovida por instituições que organizam eventos (cursos livres, feiras, encontros etc.) com o propósito de educar um público heterogêneo. Ela desenvolve-se de acordo com os interesses do sujeito. Já a educação informal ocorre de forma espontânea na vida do dia-a-dia em meio às 
conversas e vivências com familiares, amigos e demais interlocutores. Chagas (1993), Gouvêa e Leal (2001), Colley et all (2002), Vieira et all (2005), Bianconi e Caruso (2005), estão em acordo com essa concepção. Alves, Passos e Arruda (2010), por sua vez, concordam com a perspectiva exposta e acrescentam que a educação formal resulta em uma certificação e é intencional, já a educação não formal não leva à certificação. No entanto, também é estruturada e intencional. Por fim, a educação informal é marcada por não ser estruturada e não levar à certificação, sendo, frequentemente, não intencional ou incidental.

Jacobucci (2008) defende que o espaço formal é o espaço escolar, próprio das Instituições Escolares da Educação Básica e do Ensino Superior, definidas na Lei 9394/96 de Diretrizes e Bases da Educação Nacional. E infere que o espaço não formal é qualquer espaço diferente da escola, no qual acontece uma ação educativa. Essa autora alerta para o fato de que apesar de a distinção entre formal e não formal no campo teórico parecer óbvia, no campo da prática ela não é tão explícita. Por exemplo, no que se refere às estratégias de ensino, geralmente considera-se que na educação não-formal são utilizadas ferramentas didáticas atrativas. Entretanto, a autora salienta que há professores que utilizam estratégias pedagógicas variadas, diferenciadas dos métodos tradicionais e que também se encontram propostas bastante tradicionais e autoritárias sendo realizadas em espaços não-escolares. A autora sugere duas categorias para os espaços não formais de educação, locais que são Instituições e locais que não são Instituições. Na primeira, estão incluídos os espaços regulamentados, com equipe técnica responsável pelas atividades executadas. É o caso dos MCC, Parques Ecológicos, Jardins Botânicos, Planetários e outros. Na segunda, estão contemplados o parque, a casa, a rua, o cinema, o campo de futebol e outras instâncias que não estão situados em instituições com finalidades educacionais.

Marandino (2009) fomenta a discussão sinalizando que a caracterização e a diferenciação dos espaços de educação não-formal não se constituem tarefas simples. Os termos formal, não-formal e informal frequentemente são utilizados de maneira controversa: o que é considerado por alguns como educação não-formal, outros denominam de informal, tornando o consenso uma meta a ser alcançada. Nesse sentido, Rogers (2004) e Pérez e Moliní (2004) lançam uma proposta interessante, indicando uma certa fluidez na categorização formal, não formal e informal. Esses autores 
propõem que estas três instâncias deveriam ser vistas como um contínuo e não como categorias estanques. Nessa perspectiva, um museu seria nomeado de espaço de educação não-formal quando o pensamos como instituição, com um projeto estruturado e um determinado conteúdo programático. Mas também pode-se considerá-lo como educação formal quando ele se torna uma atividade estruturada pela escola, na busca de aprofundamento conceitual. E, ao mesmo tempo, pode-se imaginá-lo como educação informal enquanto opção de divertimento de um visitante, com seus amigos, familiares etc., durante um final de semana.

Nos últimos anos, autores (FALK, 2002; DIERKING, 2005; YAEL BAMBERGER, 2006) têm utilizado o termo aprendizagem por livre escolha (freechoice learning) para definir a educação que ocorre fora da escola e evitar controvérsias quanto aos termos formal, não formal e informal. A característica da aprendizagem por livre escolha estaria em o sujeito ser a origem do aprendizado, não sendo esta imposta por elementos externos, e que ela se dá ao longo da vida. Ela ocorre em museus, centros de ciências, organizações comunitárias e nas mídias impressa e eletrônica.

Conquanto haja diversas maneiras de nomear e definir a educação fora da escola, percebe-se pela discussão aqui apresentada que há uma convergência de ideias que reconhecem a educação fora da escola como sendo importante para a formação dos sujeitos. Também é uma perspectiva comum a de que os MCC se configuram como importante espaço em que essa educação pode ocorrer. Nesse sentido, é possível identificar o crescimento da proposição educativa durante as mudanças pelas quais os MCC passaram ao longo dos anos.

Diversos autores têm mostrado a evolução dos MCC (CAZELLI, 2005; GRUZMAN E SIQUEIRA, 2007; MCMANUS, 1992; CAZELLI ET AL, 1999; WAGENSBERG, 2000; PÉREZ E MOLINÍ, 2004, CHAGAS 2993; PEDRETTI, 2006), ressaltando a mudança dos agrupamentos aleatórios dos gabinetes de curiosidades para as bibliotecas e os museus com finalidades educativas. Nessa literatura é possível identificar a influência de diferentes tendências pedagógicas nas práticas educativas e a busca por uma maior interação com o público nessas instituições.

A vocação educativa do museu é cada vez mais reconhecida, o que se pode perceber pela definição de museu, a qual elenca as funções de preservar, conservar, pesquisar, comunicar e expor, à serviço da sociedade, voltadas para o estudo, o deleite e 
a educação (ICOM, 2001). Assim, alguns dos desafios impostos aos museus tem sido o desenvolvimento de estratégias que mantenham o entusiasmo do visitante real, cativo, e promovam uma aproximação dos grupos tradicionalmente excluídos. Esta forma de pensar os museus vem exigindo soluções conciliatórias entre os métodos tradicionais de comunicação realizados por esses espaços (com características dos processos comunicacionais de massa) e outros que possibilitem o intercâmbio de ideias entre as partes envolvidas (o público e a equipe do museu).

Na perspectiva dos MCC enquanto espaço de educação, também encontramos a necessidade de estratégias que dialoguem com o público, o estimulem a conhecer a ciências e forneçam informação científica de qualidade. No enfrentamento dessa realidade, os museus têm recorrido a um conjunto de técnicas de comunicação, tais como computadores, vídeos, painéis animados, teatro e outros. Nessa pesquisa, nos centraremos nas estratégias que envolvem o teatro.

Do que expusemos até o momento podemos sintetizar que, tanto da perspectiva teórica da divulgação científica, quanto da educação, os MCC têm caminhado para se constituírem enquanto um espaço em que se privilegia a realização de atividades que mobilizem a atenção do visitante, despertem a curiosidade e contemplem a interação (nos níveis sensório-motor, cognitivo e emocional), bem como promovam alfabetização científica. E que, dependendo do referencial teórico adotado, as atividades podem se percebidas tanto como ações de divulgação da ciência quanto de educação.

Nesse contexto o teatro mostra-se como uma potencial atividade museal, capaz de auxiliar essas instituições na resposta à demanda apresentada. Enquanto estratégia de comunicação em massa, ele mobilizaria a atenção do visitante, uma vez que a encenação favorece que o espectador se concentre em uma cena ou evento. A atmosfera de ludicidade criada pelo teatro favorece esse envolvimento. $\mathrm{O}$ enredo abordando questões a serem resolvidas, contemplando os aspectos conceituais, sociais, filosóficos e históricos das ciências e da tecnologia, pode ser construído de maneira a despertar a curiosidade e o interesse do espectador, especialmente se são acrescentados conflitos da vida cotidiana. Por fim, diferentes níveis de interação podem ser estabelecidos: tanto com a plateia na posição de maior passividade, o que geralmente acontece no teatro tradicional, de palco italiano, em que o espectador assiste a trama e interage emocionalmente e cognitivamente; quanto às propostas tais como o teatro fórum 
(BOAL, 1980), em que a plateia participa efetivamente do espetáculo, interagindo também no nível sensório-motor.

Conquanto não tenha sido encontrado um evento específico na história dos MCC que marque o surgimento do Teatro dentro dessas instituições, pudemos delinear os fatores que possibilitaram essa articulação. Com esse entendimento de quando os MCC passam a se apropriar do Teatro passaremos à discussão sobre como isso vem ocorrendo.

\section{2 - Teatro + Ciências = Teatro Científico?}

O teatro com temática científica vem sendo chamado pela literatura inglesa de science theatre e museum theatre. Black e Goldowsky (2000) o definem como uma maneira de relacionar conceitos científicos com seu contexto social e apresentar assuntos complexos e controversos de maneira inteligível e multifacetada, que vem sendo utilizada por museus, zoológicos e aquários. Na literatura de língua portuguesa temos encontrado o termo teatro científico.

De acordo com Saraiva (2007), a expressão teatro científico é recente e sua utilização não é consenso. Essa autora argumenta que esse termo geralmente engloba espetáculos que ocorrem em MCC ou em escolas, com a preocupação de abordar os temas científicos numa vertente pedagógica. A finalidade é a transmissão de conhecimentos para um público-alvo, normalmente, estudantes. Os espetáculos abordam conceitos científicos, muitas vezes complexos e complicados, de forma lúdica e agradável, visando torná-los mais acessíveis, remetendo posteriormente a discussão para a sala de aula.

Consideramos ser necessário ressaltar um aspecto do termo teatro científico que tem sido negligenciado pela literatura, ao menos pelos autores a que recorremos nessa pesquisa: esse termo carrega consigo a conotação de que somente nesse teatro há Ciência, o que subliminarmente tem significado as ciências da natureza. Isso pode ser facilmente constatado pelos exemplos de espetáculos apresentados pela literatura para o que seria o teatro científico.

Além disso, entendemos que a denominação teatro científico tende a ignorar o próprio teatro enquanto campo de produção de conhecimento e a desconsiderar a pesquisa nesse campo, que vêm crescendo e procurando se legitimar. Desde 1998, com 
a criação da Associação Brasileira de Pesquisa e Pós-Graduação em Artes Cênicas (um esforço de diversas universidades brasileiras $^{2}$ ) e com o apoio do $\mathrm{CNPq}$, se tem constatado um aumentado das pesquisas e dos programas brasileiros de pós-graduação em artes cênicas, resultante de representação da área em agências de coordenação e de financiamento, de reuniões científicas e artísticas periódicas e da divulgação das pesquisas. O impacto dessa nova organização pode ser percebido, por exemplo, pelo aumento no número de teses e dissertações registradas na CAPES, que no quinquênio de 2000-2005 saltou de 121 para $220^{3}$. Outro aspecto a ser considerado é que atualmente existem espetáculos teatrais que são o puro resultado de experimentos de corpo, de voz, de encenação, entre outros, ou seja, configuram-se como resultado de procedimentos metodológicos envolvendo revisões bibliográficas, experimentações, sistematização de dados e produção de novos conhecimentos, ou seja, ciência, sem sequer tocar no universo das ciências da natureza. A rigor, consideramos que esse último seria o teatro científico.

Isto posto, adotaremos nessa pesquisa o termo teatro com temática científica no lugar do termo teatro científico. Com esse termo pretendemos designar propostas teatrais que na encenação abordam tanto as ciências da natureza, quanto as ciências humanas entre outras, seja como conteúdo conceitual, histórico, filosófico, cultural ou epistemológico, seja como inspiração artística. Nessa pesquisa, entretanto, discutiremos sobre propostas teatrais que contemplam as ciências da natureza e suas tecnologias, em especial as que ocorrem em MCC.

A articulação entre o Teatro e as Ciências da Natureza não é um fenômeno recente. Brouwer $(1988,1994)$ apresenta uma discussão sobre a imagem de cientistas em algumas peças teatrais. As visões de cientistas que emergiram das peças os retratam como (i) sujeitos que acreditam na ciência como desenvolvimento do conhecimento por amor ao próprio conhecimento, (ii) sujeitos para os quais o único propósito da ciência é aliviar as adversidades da existência humana e (iii) sujeitos que acreditam poder

\footnotetext{
${ }^{2}$ Universidade Federais da Bahia (UFBA), do Rio de Janeiro (UNI-RIO e UFF), do Rio Grande do Sul (UFRGS), da Paraíba (UFPB), de Pernambuco (UFPE), do Rio Grande do Norte (UFRN), de Viçosa (UFV) e das Universidades Estaduais de São Paulo (USP e UNICAMP), de Santa Catarina (UDESC), bem como da Pontifícia Universidade Católica de São Paulo (PUC/ SP). Fonte: site da Associação Brasileira de Pesquisa e Pós-Graduação em Artes Cênicas, disponível em http://portalabrace.org/portal/.

${ }^{3}$ Dados retirados do banco de teses da capes (http://capesdw.capes.gov.br/capesdw/).
} 
convencer os adversários e opressores através da explicitação da superioridade de um sistema. As peças analisadas demonstram que o papel do cientista na sociedade tem sido um tópico muito abordado após a Segunda Guerra Mundial, possibilitando sua utilização como introdução para discussões sobre a responsabilidade social de cientistas e sobre a imagem dos cientistas na sociedade. Já Barbacci (2002) analisa como o tema inteligência artificial é abordado em cena por três espetáculos, a saber, R.U.R. Rossum's Universal Robots, do escritor e dramaturgo Karel Capek, Il cervello nudo, de Giuseppe O. Longo e a adaptação para teatro de I Cinque di Cambridge, de John L. Casti e adaptado por Luca Scarlini. Ao refletir sobre essas obras, Barbacci (2002) sinaliza para a proficuidade do teatro com temática científica quando a relação deste com a ciência resulta em reflexões que transcendem os limites do conteúdo, focalizando o homem e sua essência, dando voz às questões a respeito do sentido da vida e do mundo.

Frazzetto (2002) também dedica um artigo à difusão de peças teatrais com temáticas científicas. Nesse texto o autor salienta que Arte e Ciência frequentemente são consideradas produções diametralmente opostas. A Arte é vista como provocativa, como criatividade, baseada em idiossincrasias e entretenimento. Ela não se destinaria à razão, à solução de concepções errôneas, mas ao questionamento e, algumas vezes, à modificação de pontos de vistas bem estabelecidos. Já a ciência é considerada como racionalidade metódica, caracterizada por observações e explicações e teorias construídas sobre fatos. Cuomo (2006), por sua vez, analisa as produções de Tom Stoppard (Arcadia, Hapgood etc), Michael Frayn (Copenhage), Carl Djerassi (An Immaculate Misconceptions, Oxygen) e John D. Barrow (Infinities) e defende o teatro como comunicador de ideias científicas. Ele ressalta que a fissão do urânio e a explosão da bomba atômica de Hiroshima e Nagasaki provocaram mudanças na percepção da ciência entre especialistas em física, demais cientistas e entre não cientistas. Ressalta que a discussão sobre conseqüências catastróficas da pesquisa científica marcou a produção filosófica, sociológica e artística posteriores à segunda grande guerra.

Em estudo realizado sobre o texto Copenhage, Silveira et all (2009) o consideram um material rico em termos de exploração de aspectos sociais e dos dilemas éticos na ciência, em especial sobre os dois dos principais cientistas envolvidos na teoria quântica, Niels Bohr e Werner Heisenberg. As falas dos personagens, abordando os princípios de complementaridade e incerteza, favoreceriam o caráter de divulgação científica, auxiliando também na compreensão de conceitos da física. Numa perspectiva 
social, a peça mostraria a Mecânica Quântica como o resultado de um contexto amplo, envolvendo questões éticas, podendo ser um instrumento para a discussão sobre o papel da ciência e da sua utilização na sociedade.

Focalizando o impacto do teatro com temática científica sobre os espectadores, Siqueira et all (2011) realizam uma análise de questões formuladas por espectadores ao assistirem a peça Vida de Galileu, encenada pelo Teatro Popular de Ilhéus. De acordo com esses autores, os dados revelam o interesse em conhecer mais sobre a ciência e a compreensão dela relacionada a aspectos sociais, políticos, religiosos e históricos, caracterizando a construção de uma visão humanística da ciência. Essa abordagem possibilitou ao público acessar o conhecimento científico de forma lúdica e prazerosa, exemplificando a possibilidade de utilizar o aspecto histórico para discutir a construção de modelos e conceitos científicos.

Em síntese, considerando os autores supracitados, entendemos que a proficuidade da relação Teatro e Ciência reside na possibilidade de se conhecer a ciência para além dos seus conceitos ou experimentos, focalizando uma abordagem mais humanista. Assim, cientistas poderiam ser desnudados em seres humanos, com suas emoções e conflitos, e os experimentos poderiam ser contextualizados, conhecendo-se os interferentes sociais que influenciaram nas grandes descobertas científicas. Nessa mesma perspectiva, seria problematizado o papel do cientista na sociedade, e sua imagem, questões a respeito do sentido da vida e do mundo e os dilemas éticos, políticos, religiosos e históricos relacionados à ciência.

Alguns pesquisadores da área da divulgação científica (ABREU, 2001; MASSARANI, 2004) entendem a arte com temática científica como evolução das formas de se divulgar a ciência. A interação entre a ciência e a arte ofereceria maneiras diferenciadas de se representar o mundo (MATOS, 2003; LOPES, 2005; MASSARANI E ALMEIDA, 2006). Essa nova possibilidade traria consigo a perspectiva adicional de abordar o aspecto emocional, já que os textos científicos não incluem a emoção da descoberta. Emoção é a orientação que o diretor do Museu da Ciência de Barcelona (CosmoCaixa), Jorge Wagensberg, sugere para um maior sucesso na comunicação de conhecimento científico para o público, uma vez que ela não impõe barreiras sociais ou econômicas (BARATA, 2003). Nesse sentido, Gardair e Schall (2009) ressaltam que o teatro, assim como a ciência, nos fornece um modo de ver o mundo, sendo que para isto, esse último preocupa-se em mobilizar as emoções do espectador. Na mesma linha, 
Oliveira \& Zanetic (2004) argumentam que o teatro, ao trabalhar a sensibilidade, a percepção, a intuição e as emoções, pode levar ao público uma maior aproximação dos conteúdos científicos. O teatro, então, poderia potencializar a divulgação científica, contribuindo para uma maior aproximação da população ao conhecimento construído pela ciência e propiciar novas perspectivas de ver a ciência e o seu caráter humano.

Apesar do esforço em definir o teatro com temática científica, Magni (2002) argumenta que isso não é uma tarefa fácil já que a relação entre ciência e teatro envolve tantas nuances que não há uma expressão (ou prática) precisa que o defina e qualquer definição pode afigurar-se incompleta. Podemos perceber isso trazendo para a discussão a proposta de Gunderson (2006), que diferencia o teatro com temática científica em três tipos, i) peças com cientistas famosos como personagens, ii) peças cujos personagens são cientistas anônimos e iii) peças que utilizam a ciência como metáfora. Nessa classificação, nota-se um privilégio à figura do cientista, uma vez que duas categorias se preocupam em ressaltar o "homem" dentro de sua obra e somente uma delas se propõe a discutir a ciência, ainda assim enquanto metáfora. Essa classificação nos parece guardar certa dissonância com a proposta de Saraiva (2007). A nosso ver, Gunderson procura sinalizar que esse tipo de prática teatral é caracterizado muito mais por ter inspiração no ser cientista, na ciência e no fazer científico do que na abordagem pedagógica de conceitos de difícil compreensão.

Ao analisar a relação entre ciência e teatro, Barbacci (2002, 2004) sugere uma categorização mais abrangente, que ameniza a tensão entre as ideias de Saraiva (2007) e de Gunderson (2006). Barbacci identifica duas vertentes: o teatro usado como apoio didático para transmissão de conceitos científicos e a ciência emprestando seu conteúdo de ciência ao teatro. Dentro da primeira categoria surgem duas ramificações: (i) o teatro como técnica de apoio didático e o (ii) teatro derivado das conferências científicas. Da segunda categoria decorrem as perspectivas do (iii) teatro abordando questões éticas sobre a responsabilidade da ciência e dos cientistas, (iv) o teatro apontando uma reflexão existencial, o (v) teatro encenando biografias ou episódios da história da ciência e o (vi) teatro usando a ciência (neurobiologia, antropologia, anatomia etc.) como apoio para a criação artística. Quando das possibilidades (i) e (ii) os elementos do teatro (luzes, som, "vocabulário dramático" etc.) ajudam na aproximação entre público leigo e universo da ciência devido à sua principal força, a comunicação emotiva e sensória. Assim, atividade pedagógica e entretenimento assumem o objetivo principal 
de despertar a curiosidade sobre o mundo da ciência. Essa prática é frequente em museus, instituições científicas, e "shows de ciências". Nas ramificações iii, iv, v e vi, a criação dramática é inspirada pela ciência sem qualquer propósito específico de comunicação de conteúdos e continua mantendo suas características artísticas e estéticas, objetivando incrementar a imaginação científica do público. Nessa perspectiva, o teatro evidencia aspectos da ciência como elementos para uma reflexão existencial, levando o homem a questionamentos profundos a respeito do sentido da existência no mundo e da responsabilidade pelos seus feitos, gerando questões sobre o sentido da história, da vida e da morte.

Apesar de a proposta de Barbacci $(2002,2004)$ ser mais abrangente, percebe-se em seu interior a persistência da dissonância que sinalizamos entre Saraiva (2007) e Gunderson (2006), qual seja, a tensão entre a perspectiva de um "teatro educativo" (ou pedagógico), com foco na aprendizagem de conceitos científicos, e um "teatro arte", com o foco no teatro enquanto obra de arte e a ciência como mais outro assunto que ele pode abordar. O que estaria em jogo entre essas duas perspectivas? O teatro com temática científica deixa de ser arte por assumir um caráter mais pedagógico? Por discutir sobre ciência?

Bião (2009) discute sobre a relação da arte com outros campos. Para esse autor, a arte, entendida como fenômeno revelador e constitutivo da vida e do ser humano, constrói realidades e sentidos, cujas dimensões não se limitam às proposições (ou intenções) de outros construtos, tais como a ciência, a educação, a política, a religião, o racional da vida cotidiana, dentre outros. Contudo, momentaneamente, ela pode submeter-se a quaisquer desses construtos, reduzindo temporariamente suas dimensões artísticas às dimensões do imaginário e do simbólico dos discursos da ciência, da educação, da política, da religião, do dia a dia etc., sem diluir-se completamente. O que é caracteristicamente artístico poderá sempre persistir, ou seja, a arte pode se servir de todos os paradigmas simbólicos e imaginários, sem se submeter a nenhum deles. Nessa perspectiva, e com a qual concordamos, o teatro com temática científica continua sendo arte.

Esse tipo de espetáculo teatral, que se destina a discutir a ciência, pode encontrar denominação em práticas teatrais tais como o teatro de tese e o teatro didático. De acordo com Pavis (1996), o teatro de tese: 
[...] é uma forma sistemática de teatro didático. As peças desenvolvem uma tese filosófica, política ou moral, buscando convencer o público de sua legitimidade convidando-o a analisar mais a reflexão que suas emoções. Toda peça apresenta, necessariamente, numa embalagem mais ou menos discreta, uma tese: a liberdade ou a servidão do homem, os perigos da avareza, a força do destino ou das paixões. O teatro de tese não hesita, no entanto, em formular os problemas num comentário bastante didático. [...] alguns dramaturgos escreveram peças que queriam fazer o público refletir, ou até mesmo obrigá-lo a mudar a sociedade (PAVIS, 1996, p. 385).

Nessa prática de teatro é desenvolvida a denominada peça de tese, que:

[...] expõe, através da cena, questões morais ou políticas sentidas como atuais. A dialética das personagens e de seus pontos de vista oferece o instrumento ideal para encarar ideias controvertidas. Nada obriga o autor a nomear um porta voz de sua posição pessoal, nem mesmo uma personagem próxima dele. $\mathrm{Na}$ maior parte do tempo, a fábula e o peso relativo dos carateres informam a respeito da possível solução do problema exposto (PAVIS, 1996, p.282).

$\mathrm{Na}$ analise dessas definições é possível perceber identificações com o teatro com temática científica. A título de ilustração, podemos considerar o espetáculo Oxigênio (DJERASSI e HOFFMAN, 2004), que trata de uma estória fictícia abordando bastidores históricos verídicos a respeito da descoberta do gás oxigênio, realizada quase simultaneamente pelo químico francês Lavoisier, pelo farmacêutico sueco Scheele e pelo pastor inglês Priestley. A questão principal da peça é a escolha de quem deverá ser o ganhador de um Prêmio Nobel retroativo. A partir desse conflito os autores desenvolvem uma tese filosófica a respeito do que seria uma descoberta científica e da postura dos cientistas frente à ciência e à humanidade. Durante toda a trama, os aspectos políticos e morais que permeiam a dinâmica acadêmica e as escolhas em ciências têm nas personagens sua porta voz. O texto propõe uma reflexão crítica sobre o cientista e o fazer ciências (MOREIRA, 2012). Por meio do enredo, questões morais e políticas a respeito do fazer ciências, válidas à época e plenamente aplicáveis aos dias atuais, são problematizados. 
A peça de Djerassi e Hoffman, assim como outras mencionadas nesta pesquisa, tem como objetivo geral provocar a reflexão e instruir o público acerca de assuntos referentes à ciência e, por isso, se identificam com a ideia de teatro didático.

É didático todo teatro que visa instruir seu público, convidandoo a refletir sobre um problema, a entender uma situação ou a adotar uma certa atitude moral ou política. Na medida em que o teatro geralmente não apresenta uma ação gratuidade provada de sentido, um elemento de didatismo acompanha necessariamente todo trabalho teatral. O que varia é a clareza e a força da mensagem, o desejo de mudar o público e de subordinar a arte a um desígnio ético ou ideológico (PAVIS, 1996, p. 386).

A proposição desses espetáculos com temática científica não é outra senão fazer o público refletir e, ambiçiosamente, estimular mudanças de comportamentos, funcionando como uma peça didática, a qual pressupõe que o público extraia dela ensinamentos para sua vida privada e pública (PAVIS, 1996, p.282). Nesse contexto, é possível encontrar uma filiação ideológica do teatro com temática científica no próprio campo das artes cênicas. No que se refere à proposição educativa, ao foco sobre a reflexão, e, por que não dizer, ao estímulo à liberdade intelectual, o teatro com temática científica ressoa pensamentos proposições da peça didática de Bertold Brecht.

De acordo com Koudela (1991), o contexto que permitiu Brecht propor e escrever suas peças didáticas foram a luta de classes aguçada e a própria consciência de classe. A peça didática foi criada no intuito de interferir na organização social do trabalho, e pode ser considerada uma síntese entre tendências que procuraram articular teatro e pedagogia. Ela fundamenta-se na ideia de que o atuante possa ser influenciado socialmente pelo próprio processo de construção do espetáculo e dos personagens, assumindo para si determinadas formas de agir e de posturas, bem como reproduzindo falas. A imitação de modelos sociais e a crítica a esses modelos, através das diferentes possibilidades de atuação experimentadas têm um papel importante. No processo da peça didática, a imitação não se traduz como uma maneira passiva de retratar a sociedade, mas sim como um processo em que, pela percepção e crítica da sociedade e de seus integrantes chega-se a uma proposta de atuação. A intenção não é a de fixar ideias no atuante, mas sim de modificar o próprio método de pensar. 
Ao que se perceber, a peça didática ensina no momento mesmo em que nela se atua. Dessa maneira, o embrião da mudança social seria lançado somente entre os participantes do espetáculo. Conquanto o foco seja mesmo os atuantes, Brecht intenciona atingir a base das instituições formadoras de ideologia, assim as apresentações públicas das peças didáticas, quando ocorriam, adquiriam função política ao demonstrar e tornar visíveis as contradições imanentes à sociedade, sempre com a proposição de provocar as instituições e explicitar suas estruturas (KOUDELA, 1991). Dessa maneira pode-se entender que, mesmo para os espectadores, a peça didática se constitui como um estímulo à liberdade intelectual, ao pensamento crítico. Com isso, podem ser consideradas um método de intervenção no pensamento e de ação no plano social, gerando crítica e comportamento político, utilizando-se para isso da exploração da relação dialética entre teoria e prática de maneira a expor as formas contraditórias da estrutura social vigente.

No intuito de explicitar a prática da peça didática Steinweg (1991) explica que o processo abrange a utilização de jogos teatrais que partem do texto para aprofundar as experiências e os conceitos sobre o mundo e a sociedade. Este mesmo autor propõe alguns itens visando manter o princípio da peça didática:

a. Regras do Jogo: São colocadas ao grupo algumas regras, antes do início das atividades.

b. Exercícios sem texto: Antes de qualquer atividade com a peça didática o coordenador propõe ao grupo alguns exercícios, dos quais ele também participa.

c. Exercícios com o texto de uma peça didática a ser trabalhada: Todo o trabalho é realizado a partir do texto da peça. $\mathrm{O}$ texto não pode ser modificado. As variações só correspondem à forma como o texto é vivenciado.

d. Versões não combinadas: $\mathrm{O}$ grupo de jogadores se divide em subgrupos que escolhem os papéis a serem jogados e representam o texto sem combinação prévia com os outros integrantes do grupo.

e. Versões combinadas: Os jogadores em subgrupo combinam como irão representar a cena. 
f. Relembrando uma situação da vida: Os jogadores relembram uma situação de vida pessoa que corresponda ao que já vivenciaram do texto e representam essa situação.

g. Versões fixadas: O grupo escolhe uma das representações já apresentadas e a reapresentam, focalizando um personagem cuja mudança de comportamento deve ser trabalhada.

h. Formas de reflexão sobre a cena: As formas de reflexão valem para qualquer etapa anteriormente descrita e ocorrem após a apresentação das cenas apresentadas.

O teatro com temática científica aproxima-se da ideia de peça didática de Brecht no que se propõe à intencionalidade educativa/pedagógica. Entretanto, se diferenciam quanto à estrutura, uma vez que a primeira tem como foco principal o espectador (a plateia), enquanto a outra o tem nos atuantes. Contudo, há que se considerar a proficuidade de um teatro com temática científica que se fundamentasse nas proposições da peça didática. Esse teatro levaria para a cena as reflexões amadurecidas criticamente pelos atuantes, utilizando-se dos recursos lúdicos para comunicar, mas com foco na reflexão. $\mathrm{O}$ objetivo seria o de entreter, mas sem nublar a percepção do espectador, colocando em evidência o estranhamento do que é socialmente comum, do ponto de vista das organizações científicas.

Procuramos explicitar o que entendemos como sendo o teatro com temática científica, para isso aprofundamos no questionamento a respeito do termo teatro científico, explicitando suas limitações, e procuramos demonstrar uma relação entre essa prática de teatro e a peça didática de Brecht. Temos consciência de que várias questões a respeito dessa prática ainda estão em aberto, e atribuímos a essa percepção à própria característica dessa atividade que, conforme demonstraremos a seguir, ainda é inicial no âmbito brasileiro, exigindo um debruçar acadêmico sobre ela.

\section{3 - Experiências de Teatro e Ciência no Brasil}

No Brasil, encontram-se alguns núcleos que exploram a interface entre Teatro e Ciências da Natureza dentro de MCC. São grupos que procuram divulgar a ciência ou educar através da linguagem teatral. Dentre eles, podemos citar projetos como o Ciência em Cena, no Museu da Vida (Fundação Oswaldo Cruz). Os principais objetivos desse 
espaço são a pesquisa sobre ciência e arte e o desenvolvimento de atividades artísticas que promovam a apresentação e discussão de temas da ciência. Ele é constituído por uma equipe multidisciplinar, com profissionais das áreas de artes, ciências, pedagogia e técnicos, e conta com a Tenda do Ciência em Cena, um cine-teatro para duzentas pessoas, e o Epidaurinho, um anfiteatro para quarenta pessoas, dois palcos externos e uma ilha de edição e equipamentos de filmagem (LOPES, 2005).

Na programação de atividades desse espaço, o teatro é um dos recursos artísticos mais explorados, sendo que esse projeto já realizou diversas montagens de espetáculos. O mensageiro das estrelas, de Ronaldo Nogueira da Gama, no qual é abordada a vida e a obra do italiano Galileu Galilei, foi o primeiro. Mais do que mostrar Galileu e suas teorias, a peça se propõe a discutir o impacto e as implicações destas na sociedade e sua influência sobre os rumos da ciência. Nela, é enfatizado o espírito criativo de Galileu, apresentado como um ser humano questionador, capaz de colocar em cheque até as ditas verdades absolutas (LOPES, 2000). Em Lição de botânica, de Machado de Assis e direção de Gustavo Ottoni, também encenado no mesmo espaço, o público é convidado a viajar para o Rio de Janeiro do início do século XX e assiste o botânico sueco Barão Sigismundo de Kernoberg se apaixonando, ao mesmo tempo em que tenta impedir que o sobrinho se case. Em meio a um conflito entre sentimentos e carreira científica são apresentadas discussões sobre ser cientista e fazer ciência, além dos nomes científicos de algumas plantas. No espetáculo $O$ mistério do barbeiro, direção de Jacyan Castilho, o foco está na história do cientista Carlos Chagas, em especial na descoberta do mal de Chagas e em informações sobre contágio, transmissão e o agente transmissor da doença. Também explora a relação entre Chagas e Oswaldo Cruz, por ocasião da criação do Instituto Manguinhos (MASSARANI, 2008). Já Pergunte a Wallace, escrita por Geinor Styles adaptada por Gustavo Ottoni e Wanda Hamilton, revela a trajetória intelectual do naturalista galês Alfred Russel Wallace, co-criador da Teoria da Evolução por Seleção Natural, que viajou pelo Brasil entre 1848 e 1852. Nesse espetáculo, o cientista aparece como um jovem aventureiro, fascinado pela natureza. E Sangue ruim, escrita por Paul Sirett e adaptada por Wanda Hamilton, Luisa Massarani e Rosicler Neves, debate questões éticas em torno da pesquisa com seres humanos. O contraste cultural entre 
Claire, uma pesquisadora inglesa, e Patrice, jovem africano, é a base em que se fundamenta a narrativa ${ }^{4}$.

Em diversos desses espetáculos, ao final, abre-se um debate com o público, buscando esclarecer dúvidas e fazer comentários e sugestões. Lopes (2005) sinaliza que está é uma postura importante quando se utiliza a linguagem teatral na veiculação de conceitos do campo das ciências ou pretende-se despertar vocações científicas. Além das peças de teatro, há improvisações teatrais e jogos dramáticos que relacionam biologia e cultura na atividade Laboratórios de percepção. Essa atividade possibilita ao visitante experienciar como a cultura e a emoção influenciam na organização das informações aprendidas pelos sentidos.

O Palco da Ciência, na Casa da Ciência, é outro projeto que se propõe a reunir, promover e divulgar produções teatrais que tenham a ciência por motivação. Apesar de já abordar a linguagem teatral desde sua fundação, é a partir de 1999 que elas ganham vida própria e têm espaço garantido na programação, independente da atividade em cartaz. Desde 1999, já foram apresentadas 12 peças (SOARES, 2003). Entre os espetáculos abrigados por esse projeto estão o Em busca da estrela, texto de Larissa Câmara e direção de Chayanna Ferreira; Um voo para Santos Dumont, texto e direção de André Brilhante; Dumont - O sonho de um voador, texto de Mauro Barros e direção de Marcia Fernandes e Mauro Barros; Dançando no céu, Texto de Stela Guedes Caputo e direção de Max Pereira Roca; O picadeiro em busca do tempo perdido, texto de André Brilhante e direção de Renato Carrera; E Einstein, texto de Gabriel Emanuel e direção de Sylvio Zilber ${ }^{5}$.

No Seara da Ciência também encontramos ações de artes cênicas. O Seara é um espaço de divulgação científica e tecnológica da Universidade Federal do Ceará que procura estimular a curiosidade pela ciência, cultura e tecnologia, mostrando suas relações com o cotidiano e promovendo a interdisciplinaridade entre as diversas áreas do conhecimento. Dentre as ações desse espaço está a representação teatral. Um grupo de teatro se apresenta em atividades desenvolvidas pela própria Seara ou a convite de

\footnotetext{
${ }^{4}$ Fonte: Museu da Vida, www.museudavida.fiocruz.br, acessado em 12/10/2011.

5 Fonte: http://www.casadaciencia.ufrj.br/palco/frameset_espetac.html, acessado em 12/10/2011.
} 
outras instituições. Os textos têm como objetivo transmitir conceitos científicos de forma simples, lúdica e agradável, na forma de diálogos bem humorados, motes para posteriores debates em sala de aula. Algumas das peças apresentadas são Eu odeio insetos e Caixinhas da vida, de Betânia Montenegro e Ricardo Tannus e Digestão: comida, calor e peso, de Betânia Montenegro, contam ainda com a adaptação do texto Tem um cabelo na minha terra, de Gary Larson, na qual é abordado o tema equilíbrio ecológico. A trajetória e as contribuições de cientistas como o físico, matemático e filósofo alemão Albert Einstein, o químico francês Antoine Laurent Lavoisier e o naturalista inglês Charles Darwin também foram adaptadas em monólogos e encenadas por esse grupo. A principal obra do grupo tem sido Bioquímica em cena, de Marcus R. Vale, uma peça que tem como objetivo abordar as relações metabólicas mantidas entre vários sistemas do organismo humano (MONTENEGRO ET AL, 2005).

Em Pernambuco, encontramos o Espaço Ciência, que tem como objetivo estimular a curiosidade científica e a popularização de informações significativas em Ciência e Tecnologia. Situado em uma área de 120 mil metros quadrados entre Recife e Olinda é um dos maiores museu de céu aberto do mundo. Há 13 anos ele se constitui em uma opção de lazer, conhecimento, iniciação científica e inclusão social. Entre os projetos desenvolvidos por este espaço está o Laboratorium Cênico, que tem nos recursos do teatro um meio de vivenciar novas estratégias de comunicação e interação com o público. Dentre os espetáculos já encenados estão Mateus e Catirina em o calor tá de rachar, onde personagens da cultura local explicam o que é aquecimento global, o Desadmirável Mundo Novo, retrata história do despertar de um cidadão comum que depois de um pesadelo com um futuro de caos, decide fazer a diferença através da mudança em pequenos hábitos, e Show da Ciência: Tudo numa Folha de Papel, no qual vários experimentos são realizados com a participação do público ${ }^{6}$.

No estado de São Paulo, temos o Núcleo de Artes Cênicas da Estação Ciência com a Cia. Fábula da Fíbula. Este grupo constitui o objeto de análise desta pesquisa, assim, delinearemos o trabalho por ele realizado na caracterização do objeto, no capítulo acerca do método adotado nesta pesquisa.

É imprescindível citarmos aqui alguns projetos e ações que, apesar de não se configurarem como o objeto a que nos propomos analisar, qual seja o teatro com

\footnotetext{
${ }^{6}$ Fonte:www.ufpe.br, acessado em 12/10/2011.
} 
temática científica dentro de MCC, têm contribuído para a disseminação da articulação entre teatro e ciência no Brasil. O Arte e Ciência no Palco é um dos pioneiros na interface teatro e ciência. Ele foi criado em 1998 pelo ator Carlos Palma e Adriana Carui e em 2001 se consolidou junto a Cooperativa Paulista de Teatro. O núcleo Arte e Ciência no Palco dedica-se ao fazer teatral pensando no homem e na sociedade com a lente da ciência, investigando a relação entre arte e ciência. No seu repertório contam 12 espetáculos em mais 10 anos de atuação, dentre eles estão os premiados Einstein (Prêmio Mambembe / FUNARTE em 1998,), Da Vinci pintando o sete (Prêmio Maria Clara Machado), Copenhagem (Prêmio Qualidade Brasil e Prêmio Shell, em 2001), Quebrando Códigos (Prêmio Shell, em 2004), 20.000 léguas submarinas (Prêmio FEMSA, em 2004) e Perdida, uma comédia quântica, After Darwin, A dança do universo, Rebimboca \& Parafuseta e A culpa é da ciência?. Os espetáculos são encenados por atores profissionais e contam com a assessoria/colaboradores do campo da ciência, da educação e da divulgação científica ${ }^{7}$.

Outro projeto que merece destaque é o Ouroboros, da Universidade Federal de São Carlos. A proposta do Núcleo Ouroboros de Divulgação Científica é aproximar a população em geral dos conhecimentos e do meio cultural vivido nas universidades, divulgando a ciência e a cultura por meio do teatro e de oficinas de circo. O projeto está sob a direção geral da Profa. Karina Lupetti e, ao longo de sua história, encenou os espetáculos Além da Lenda, Magia x Ciência, O químico e o monstro, O castelo bem assombrado, A caverna de Morgana, Lição de botânica e Estava escrito nas estrelas, dentre outros ${ }^{8}$. O Ouroboros foi um dos grandes responsáveis pela criação do evento Ciência em Cena, destinado a reunir grupos de teatro que divulgam a ciência por meio do teatro (LUPETTI et all, 2008). Esse evento tem periodicidade anual e vem sendo realizado desde 2007. Nele, são realizados mini-cursos, oficinas, mesas redondas e apresentações de peças teatrais, visando a troca de experiências e a formação dos participantes para atuação na divulgação científica por meio do Teatro. Os participantes variam desde os estudantes de graduação aos profissionais da área de Artes Cênicas. Em sua quarta edição (2010), o evento contou com a participação de 13 grupos, incluídos dois grupos de Portugal. No ano de 2011, o evento retornou a São Carlos para, em 2012,

\footnotetext{
${ }^{7}$ Fonte: www.arteciencianopalco.com.br, acessado em 12/10/2011.

${ }^{8}$ Fonte: http://www.ufscar.br/ouroboros, acessado em 12/10/2011.
} 
ser realizado na cidade de Caxias (MA), sob a organização do grupo teatral LETRAFISIC. Também no intuito de promover o encontro entre os diversos sujeitos envolvidos na interface entre teatro e ciência, em julho de 2011, o Museu da Vida promoveu o Ciência e arte em cena: um intercâmbio de experiências, reunindo atores e diretores brasileiros e britânicos, bem como pesquisadores em divulgação científica. Outras iniciativas também são realizadas pela Casa da Ciência (Universidade Federal do Rio de Janeiro) no ciclo de palestras do projeto Ciência para Poetas.

Ao discutir sobre o trabalho realizado por algumas das companhias supracitadas, Montenegro et all (2005) reforça a importância da linguagem teatral, enquanto meio, para divulgar e popularizar a ciência. Nesse sentido, Mateus (2005) relata que a montagem e apresentação do espetáculo "Frankenstein: a ciência no divã" tem possibilitado a estudantes de graduação e de pós-graduação, que compõem o elenco, o desenvolvimento de habilidades de comunicação e conhecimento do processo de transposição didática; e, aos espectadores, o contato com informações sobre ciências de maneira mais prazerosa do que a rotina de sala de aula. Também Lupetti et al.(2007a; 2007b; 2007c), considerando os resultados obtidos com questionários respondidos por espectadores de peças teatrais focalizando a Ciência, têm relatado que o teatro, enquanto atividade suplementar às desenvolvidas em sala de aula, é uma importante ferramenta para a divulgação e ensino de ciências, uma vez que desperta o interesse de crianças e jovens para vida cultural e científica.

A articulação entre Teatro e Ciências da Natureza no Brasil, visando à divulgação científica, é ainda recente e, por isso, apresenta diversos aspectos que precisam ser melhor estudados. Por exemplo, Lupetti (2006) relata problemáticas que o grupo Ouroboros enfrenta por seus integrantes não possuírem formação em artes cênicas. De uma perspectiva contrária, Carlos Palma, diretor do projeto Arte e Ciência no palco, também relata em entrevista (MASSARANI \& ALMEIDA, 2006) a resistência de atores profissionais em trabalhar com temáticas científicas, já que o processo de construção dos personagens envolve a compreensão dos conceitos científicos. O fomento à pesquisa na interface Teatro e Ciência é indispensável para que essa temática seja discutida com fundamentação científica, para que se tenha uma maior difusão em revistas de pesquisa e para que sejam produzidas perspectivas que auxiliem curadores, professores e pesquisadores interessados em desenvolver projetos nesse âmbito. No bojo dessa discussão é que se insere a pesquisa aqui apresentada. 
O MÉTODO 


\section{1 - Abordagem metodológica}

Esta pesquisa foi realizada na perspectiva da análise qualitativa (LUDKE \& ANDRE, 1986; BOGDAN \& BIKLEN, 1994). A preocupação foi entender como o teatro no contexto dos Museus e Centros de Ciências (MCC) se insere na perspectiva da alfabetização científica, bem como desvelar suas características enquanto atividade museal. Assim, inicialmente foram desenvolvidas proposições teóricas que orientaram a coleta de dados e que direcionaram nossas opções metodológicas conforme apresentado na figura 3.1.

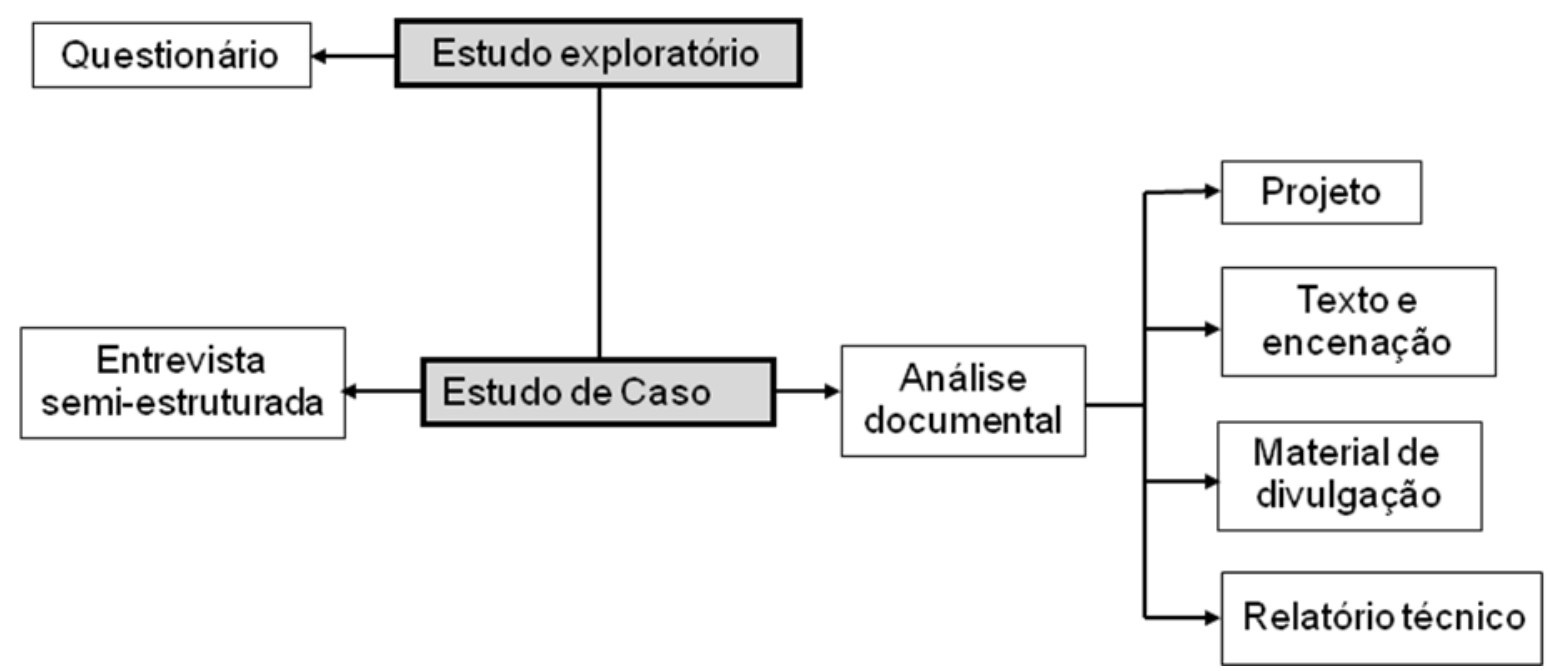

Figura 3.1: Organograma da pesquisa.

\section{2 - O estudo exploratório}

Como uma maneira de nos apropriarmos melhor de nosso objeto de análise realizamos um levantamento qualitativo inicial dos MCC Brasileiros que desenvolvem atividades do campo das Artes Cênicas, na tentativa de delinear como esses espaços têm se apropriado desse recurso. Os Museus e Centros de Ciências que participaram dessa etapa foram selecionados tendo como referência o catálogo Centros e Museus de Ciência do Brasil 2009, produzido pela Associação Brasileira de Centros e Museus de Ciências (ABCMC). Optou-se por esse critério de seleção pelo entendimento de que a ABCMC é um órgão de reconhecimento nacional, com a finalidade de unir ideias, 
compartilhar experiências e de compreender as possibilidades e os limites da popularização do conhecimento científico no Brasil (BRITO et all, 2009).

É importante pontuar que a sistemática adotada para este levantamento contava com algumas facilidades, tais como uma listagem já estabelecida de instituições legitimadas pelo campo da divulgação científica e o contato dessas instituições, seja por endereço ou correio eletrônico, seja por telefone. Contudo, na prática, o contato com essas instituições não foi tão simples quanto se imaginava, por vezes havia mudanças nos endereços eletrônicos e/ou páginas on-line fornecidas pelo catálogo. Assim, como uma maneira de garantir o contato com os MCC, foi adotado o procedimento de acessar as páginas eletrônicas das instituições selecionas para verificar os correios eletrônicos fornecidos pelo catálogo. Outra problemática encontrada foi o fato de algumas instituições responderem à mensagem eletrônica informando que não desenvolviam atividades do campo das Artes Cênicas sem o preenchimento do questionário enviado. Esse tipo de retorno não foi considerado nesta etapa preliminar e, desta forma, para efeito de análise, foram consideradas somente as instituições que retornaram ao nosso contato com o questionário preenchido.

Os dados foram coletados por meio de um questionário contendo questões abertas e fechadas (Anexo 1). A finalidade desse questionário foi possibilitar o fornecimento de informações visando o delineamento das práticas de Artes Cênicas, em especial do Teatro, desenvolvidas pelos MCC. O questionário foi enviado aos diretores de $113^{9}$ instituições das 190 constantes no catálogo da ABCMC, via correio eletrônico, contendo o texto de apresentação no corpo da mensagem, com o questionário anexado. Foi obtida resposta de 46 dos correios eletrônicos enviados, porém nem todos com informações pertinentes a essa pesquisa. Algumas respostas indicavam $o$ encaminhamento para outras pessoas ou setores não constantes no catálogo, outras informavam que responderiam em momento oportuno e outras, ainda, respondiam sem preencher o questionário. Ao final, foram retornados 24 questionários devidamente preenchidos.

\footnotetext{
${ }^{9}$ Alguns endereços eletrônicos correspondiam às secretarias estaduais ou municipais de educação ou meio ambiente, não possibilitando o contato, de fato, com os MCC. Outros MCC apresentavam somente o contato por telefone.
} 
No que se refere ao tratamento dos dados obtidos, aqueles que foram fornecidos por meio das questões fechadas (múltipla escolha) foram contabilizados de maneira a explicitar a frequência de cada opção de resposta e, posteriormente, foram determinadas percentagens, quando oportuno. Quanto aos dados obtidos nas questões abertas (dissertativas), foi realizada a categorização temática, considerando como paradigma a análise de conteúdo.

O método de análise de conteúdo foi desenvolvido na primeira metade do século XX para analisar comunicações. Esse método compreende um conjunto de técnicas de análise das comunicações, que utiliza procedimentos sistemáticos e objetivos de descrição do conteúdo das mensagens. Inicialmente, voltava-se à análise de material jornalístico, passando, a seguir, a ser utilizado em vários campos de conhecimento como a crítica literária, a Psicologia, a História, a Sociologia e as Ciências Políticas, dentre outros. Atualmente, seu domínio possível de aplicação estendeu-se a comunicações feitas por uma pessoa, entre duas pessoas, em grupos e de massa, podem ser o código linguístico escrito, oral, icônico ou mesmo outros códigos semióticos (BARDIN, 2000). Nessa pesquisa, segmentamos os dados obtidos nas questões dissertativas em turnos (constituídos por trechos do texto), posteriormente agrupados em conjuntos distintos através de um processo de diferenciação e re-agrupamento para serem, então, categorizados segundo um critério semântico. Como não havia um sistema de categorias pré-estabelecido nesse processo exploratório, a categorização nesta etapa resulta da classificação analógica e progressiva dos elementos constituintes das respostas, seguindo os critérios de exclusão mútua, homogeneidade, pertinência, objetividade/fidelidade e produtividade. Esse procedimento é conhecido por "milha" (BARDIN, 2000).

\section{3 - O estudo de caso}

De acordo com Yin (2005), a investigação de um estudo de caso enfrenta uma situação tecnicamente única, em que haverá muito mais variáveis de interesse do que fontes de dados e, como resultado, baseia-se em várias fontes de evidências. Outra 
característica importante é o desenvolvimento prévio de proposições teóricas que norteiem o planejamento da coleta e análise dos dados.

O caso em estudo nesta pesquisa é o teatro no contexto dos MCC. Ao longo desta tese serão apresentados dados e reflexões visando explicitar se/como o teatro realizado nos MCC pode contribuir para o alcance da alfabetização científica. Nesse processo (e a partir do quadro teórico adotado) procuraremos construir conhecimentos a respeito dessa prática, tais como as finalidades e os aspectos organizacionais e de grupo, privilegiando a descrição da realidade.

Os dados dessa etapa da pesquisa foram coletados através de duas estratégias: entrevista e análise de documentos. A entrevista seguiu o modelo semi-estruturado, ou seja, após aprofundamento no quadro teórico adotado foi construído um roteiro de entrevista, com as perguntas sendo divididas em três grandes grupos: caracterização do projeto, o teatro no museu e a peça (Anexo II). Apesar de se utilizar uma listagem definida de perguntas, no momento da entrevista houve liberdade do entrevistador em acrescentar ou suprimir perguntas de maneira a melhor focalizar o assunto de interesse. A entrevista foi realizada pelo próprio pesquisador, tendo ocorrido no dia 15 de dezembro, ano de 2011. O entrevistado foi o Sr. Cauê Mattos, autor, ator, produtor e diretor de teatro, artista circense, dançarino, DJ e coordenador do Núcleo de artes cênicas da Estação Ciência. A divulgação da identidade do entrevistado foi autorizada por ele. A entrevista foi realizada no gabinete do entrevistado, na própria Estação Ciência, e teve a duração de 3 horas e 15 minutos. O registro foi feito por meio de uma filmadora Panasonic SDR-H80.

A documentação considerada para análise nessa pesquisa é constituída pelo projeto da encenação selecionada para estudo, submetido ao Conselho Nacional de Desenvolvimento Científico e Tecnológico ( $\mathrm{CNPq})$, pela filmagem da encenação, pelo texto da mesma, pelo material de divulgação do espetáculo (portifólio e panfletos) e pelo Relatório Técnico. Essa documentação foi disponibilizada pela Estação Ciência.

Importante ressaltar que conquanto não haja triangulação quanto aos procedimentos de coleta de dados, está é contemplada considerando-se a diversidade de documentos analisados. Assim, foi possível estabelecer ligações entre as informações obtidas pelas diferentes fontes e encontrar paradoxos e congruências que possibilitaram o melhor entendimento do fenômeno em estudo. 
Todo o material dessa etapa, tanto a entrevista quanto os documentos, foi tratado utilizando-se técnicas da análise de conteúdo. Importante ressaltar que a análise do espetáculo em si, enquanto encenação foi fundamentada também nos procedimentos para análise de espetáculos proposta no Questionário Pavis ${ }^{10}$ (Anexo III). Este questionário é um instrumento de análise proposto na obra Análise dos Espetáculos (PAVIS, 2010) e que tem sido utilizado como referência para a produção de resenhas sobre encenações. Nele, são propostos como eixos de análise as características gerais da encenação, a cenografia, a iluminação, os objetos, os figurinos, a maquiagem e máscaras, a performance dos atores, a função dos sons e do silêncio, o ritmo do espetáculo, a leitura da fábula, o texto e o espectador. Alguns desses eixos também são contemplados nas análises que Roubine (1998) e Ryngaert (1996) realizam sobre encenação teatral. Procuraremos explicitar mais adiante em que medida o conjunto desses elementos, unidos ao texto escrito, favorece o diálogo com a alfabetização científica.

\section{4 - Escolha do tema e caracterização do objeto}

Definidas as condições de contorno, isto é, que a prática teatral a ser analisada estivesse inserida em Museus e Centros de Ciências, o critério utilizado para a seleção do sujeito dessa pesquisa foi a militância reconhecida da instituição museal nas práticas delineadas e a disponibilidade em participar dessa pesquisa. Assim, foi selecionado o projeto Cia. Fábula da Fíbula, do Núcleo de Artes Cênicas da Estação Ciência (EC).

Cazelli (2005) situa a EC em um local de importância dentro da história dos espaços de ciências brasileiros. Essa autora relata que, no Brasil, a partir da década de 1980, os museus de ciência foram se afastando da característica de armazéns de objetos e se tornando locais interativos, visando à aprendizagem. A EC surge nesse período como proposta de museu que incorpora o caráter dinâmico, visando à comunicação, educação e difusão cultural. Ela nasce com a perspectiva de incorporar a mudança da prática e do papel social dos museus, bem como de atender os esforços em reduzir os níveis de "analfabetismo científico". Assim, pode-se considerar que a EC se configura como uma das instituições museais brasileiras pioneiras em propostas interativas visando à aprendizagem fora do âmbito escolar.

\footnotetext{
${ }^{10}$ Patrice Pavis é professor de estudos teatrais na Universidade de Kent, foi agraciado com o prêmio Georges Jamati de Estética Teatral em 1986. Atualmente escreve e estuda com foco em semiologia e interculturalidade no teatro.
} 
A história da criação da Estação Ciência $(E C)^{11}$ já denuncia sua vocação de preservação e difusão cultural. Os galpões da Rua Guaicurus, que hoje abrigam a EC, foram construídos no início do século XX para abrigar uma tecelagem e quase foram destruídos por um incêndio no ano de 1936 (vide figura 3.12). Depois de recuperados foram utilizados pela Secretaria de Agricultura e outros órgãos do Governo até a década de 1970. Em 1985, durante as discussões sobre o Terminal Rodoviário da Lapa, os comerciantes e líderes comunitários da pleitearam sua conservação dos galpões,

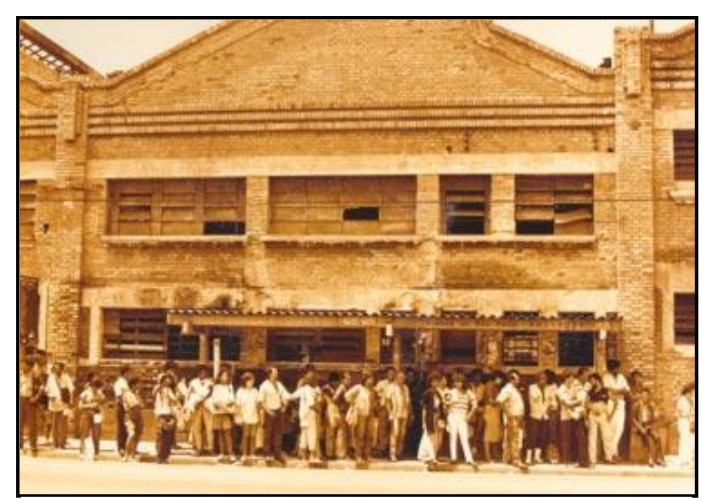

Figura 3.2: Futura Estação Ciência, década de 1940. alegando seu valor enquanto parte da história da indústria têxtil paulista e da colonização italiana. Ao final deste mesmo ano o Conselho de Defesa do Patrimônio Histórico, Arqueológico, Artístico e Turístico (CONDEPHAAT) iniciou a avaliação para tombamento desses galpões de arquitetura industrial típica do início do século XX, impedindo alterações na estrutura do prédio. Em 19 de dezembro de 1986, através do

Decreto n. 26.492, o Governo do Estado cedeu o uso de parte do imóvel ao CNPq, para a instalação do Centro de Ciência para a Juventude.

Em 24 de junho de 1987 a Estação Ciência é Inaugurada pelo Conselho Nacional de Desenvolvimento Científico e Tecnológico. A Estação Ciência já era uma ideia na década de 70, na ocasião da fundação da Academia de Ciências do Estado de São Paulo. Três anos depois, em 1990, sua administração é transferida para Universidade de São Paulo. Atualmente a EC está vinculada à Pró-Reitoria de Cultura e Extensão da USP e tem como missão oferecer oportunidades de compreensão de aspectos do conhecimento científico produzido dentro e fora da Universidade, bem como divulgar a cultura e a arte para a população. Sua área total é de $11.000 \mathrm{~m}^{2}$, estruturada para servir ao projeto de

\footnotetext{
${ }^{11}$ A descrição que apresentaremos da criação da EC, bem como das produções teatrais do Núcleo de Artes Cênicas tem como fontes de dados as informações disponíveis no site da EC, (www.eciencia.usp.br) e a entrevista cedida por Cauê Mattos à Carina Pascotto Garroti na ocasião da monografia Arte e Ciência: a popularização do conhecimento, disponível em www.abcmc.org.br/publique2/media/arte\%20e\%20ciencia3.PDF.

${ }_{12}$ Fonte: Rogério Mascia Silveira, disponível em: www.rogeriosilveira.jor.br/reportagem2007_06_21_estacao_ciencia_usp_20anos.php. As demais fotos foram retiradas do site da Estação Ciência.
} 
difusão da ciência e da cultura. A edificação atual conta com cerca de $3.000 \mathrm{~m}^{2}$ de área dedicada ao acervo expositivo e aos experimentos. Dentre os diversos espaços, possui cafeteria, auditório de 190 lugares (com camarim e sala de controle), duas salas multiuso (cursos, treinamentos e reuniões), sala de apoio ao visitante e mezanino para eventos e exposições temporárias. Nos últimos anos, o público anual de visitantes tem alcançado a marca de 400.000 visitantes presenciais e cerca de 120.000 acessos virtuais. Pela sua infraestrutura, alcance e qualidade dos processos de comunicação da ciência, da tecnologia e da cultura, é que a EC tem sido referência no campo da divulgação científica e tecnológica.

As atividades da EC envolvem exposições interativas (permanentes, temporárias e itinerantes), experimentoteca, cursos, palestras, mostras de vídeo, publicações, laboratório virtual, espetáculos teatrais e apresentações musicais. As temáticas abordadas têm escopo amplo,

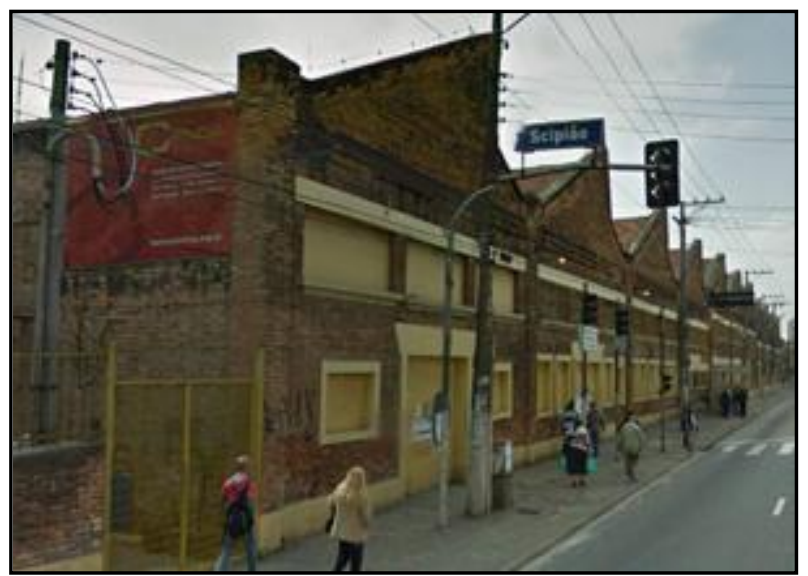

Figura 3.3: Estação Ciências. destacando-se assuntos relativos às Ciências Físicas, Astronômicas, Meteorológicas, Biológicas, Humanas e da Terra, além da Matemática, da Medicina, da Geologia e do Urbanismo. Na produção e realização de suas atividades conta com o apoio e colaboração de unidades da USP e de outras instituições públicas e privadas, bem como de cooperações e parcerias com empresas e organizações não governamentais.

Três projetos complementam as atividades educacionais da $\mathrm{EC}$, são eles o $\mathrm{ABC}$ na Educação Científica - Mão na Massa, o Projeto Clicar e o Núcleo de Artes Cênicas. $\mathrm{O}$ ABC na Educação Científica tem como foco as primeiras séries do Ensino Fundamental e busca desenvolver a observação, a discussão coletiva e o registro sobre experimentos simples, elementos que auxiliam nas expressões oral e escrita e no raciocínio da criança, além de incentivar a aprendizagem por meio da indagação. $O$ Projeto Clicar é uma parceria com Organização Não Governamental Centro de Estudos e Pesquisa da Criança e do Adolescente - atende a crianças em situação de risco social e pessoal, em parceria com a ONG Centro de Estudos e Pesquisa da Criança e do Adolescente (CEPECA), com foco na inserção digital. 
O Núcleo de Artes Cênicas foi criado no ano de 1999 com o objetivo de pesquisar

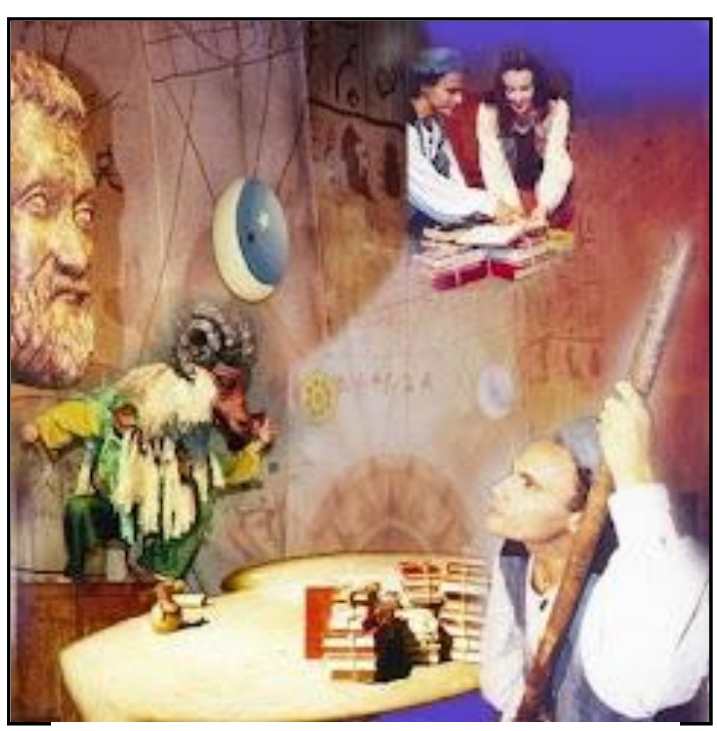

Figura 3.4: A estrela da manhã. e utilizar a inter-relação de atividades como palestras, cursos, apresentações de espetáculos de dança, teatro, circo e música. As apresentações teatrais eram realizadas pelo Grupo de Teatro da Estação Ciência. Este grupo surgiu da parceria entre a EC e a Cooperativa Paulista de Teatro e foi responsável pela encenação de diversos espetáculos, a saber: A estrela da manhã, no ano de 2000, um texto inédito de Calixto de Inhamuns e direção de Gabriela Rabelo. Esse espetáculo aborda a história do conhecimento ocidental. Nele, um jovem sonhador chamado Enzo pede a ajuda de um sábio ancião para encontrar sua amada. O sábio diz que para ajudá-lo, ele terá que responder as perguntas: Quem somos? De onde viemos? Para onde vamos? Em sua viagem em busca das respostas, Enzo recebe a companhia de uma jovem, que é designada pelo sábio pra servi-lo durante sua jornada. Enzo recebe também um determinado tempo de vida e dons especiais. Ele irá passear pelos momentos chave da história do pensamento ocidental para tentar responder as grandes questões da humanidade.

O segundo espetáculo, Conexões Cósmicas, em 2003, sob a direção de Wilton Amorin, é inspirado no painel Evolução, que faz parte do acervo de exposições da EC e foi criado pelo artista plástico Paulo Roberto Santiago e pelo professor Augusto Damineli (pesquisador em cosmologia). Esse espetáculo

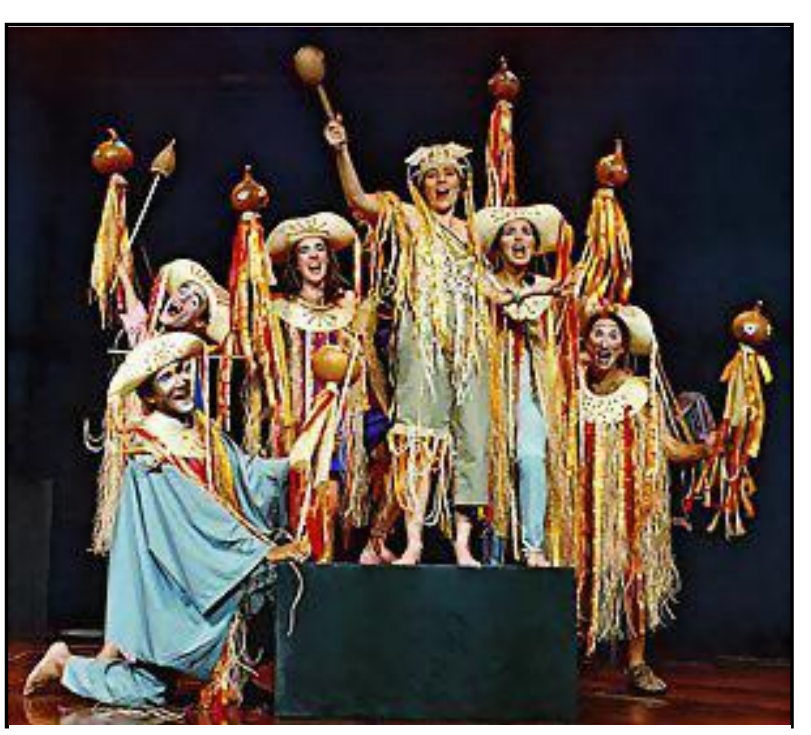

Figura 3.5: Conexões Cósmicas. propunha uma discussão sobre a teoria do Big Bang, a criação e a evolução do Universo. Teatro, música ao vivo, manifestações populares como capoeira, maracatu e 
arte circense se somam a vários recursos tecnológicos para divulgar a ciência nesse espetáculo. No enredo da peça, os integrantes de uma trupe mambembe interpretam seis povos distintos de um mesmo planeta. A cultura dos grupos representa cada período da história do universo: Era do Caos, da Grande Explosão, da Luz e das Trevas, da Formação dos Corpos Celestiais, do Desenvolvimento da Vida e Tempo Futuro. Entretanto, nenhum destes pontos de vista é completo. No final, o enigmático personagem chamado Elo (formado por todos) dá unidade, compondo uma só história. Em meio à ação cênica a trupe pontua as contradições e contraposições sobre esse tema,

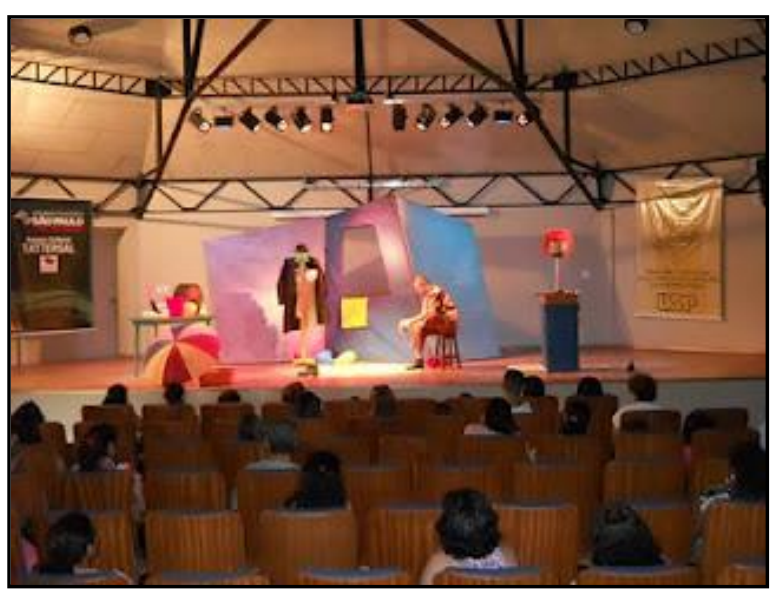

Figura 3.6: Prof. Gervásio e a energia elétrica. abordando conceitos científicos que, em um primeiro momento, podem parecer de difícil compreensão.

No ano de 2004, devido aos diversos compromissos dos atores que constituíam a trupe da EC o Grupo de Teatro da Estação Ciência acaba se dissolvendo. Surge, então, a Cia. Fábula da Fíbula, sob a coordenação do remanescente ator, produtor e diretor Cauê Mattos. Na nova configuração acontece a estreia do espetáculo Prof. Gervásio e a

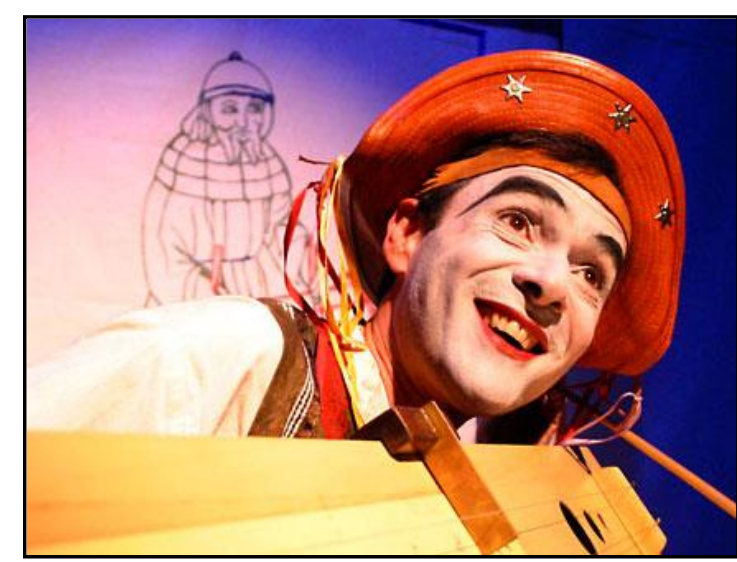

Figura 3.7: O monocórdio de Pitágoras. Energia Elétrica, ainda em 2004, com texto de Cauê Mattos e Regina Arruda e direção de Regina Arruda. Nessa aulaespetáculo, que une física e teatro, o professor Gervásio discute questões sobre energia elétrica, seus usos, sua história e os fenômenos físicos de forma leve e bem-humorada. Conceitos técnicos e científicos são abordados permitindo a interatividade dos espectadores que constroem a apresentação junto com personagem no palco. Ainda em 2004 a Fábula da Fíbula apresenta $O$ monocórdio de Pitágoras, peça que coloca em 
cena a relação entre música e matemática através das experiências realizadas com as divisões da corda do monocórdio, instrumento musical construído pelo filósofo e matemático da Grécia antiga, Pitágoras de Samos, com finalidades científicas. Inspirada na literatura de cordel, a peça tem estética nordestina, perceptível no cenário, no figurino, nos adereços, na música e no texto, que é

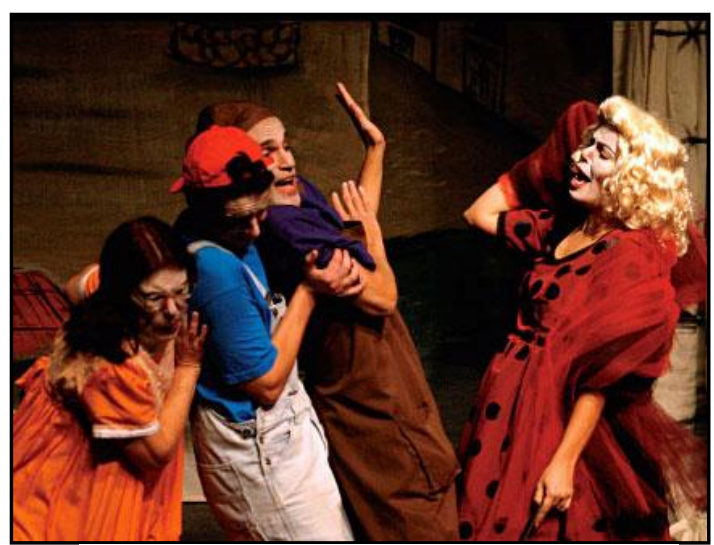

Figura 3.8: O poeta e o vento. assinado por Pedro Paulo Salles. Com direção de Cauê Mattos e cenografia de Monica Nassif, a narrativa é feita pelo personagem Severino, violeiro apaixonado pela história e pelas experiências de Pitágoras, que conta a saga do filósofo grego e de suas experimentações com o monocórdio, em meio ao público, como se estivesse numa praça. Nesse mesmo ano é apresentado mais dois espetáculos: Gestação, uma primeira incursão do Fábula da Fíbula no universo da dança. Ciência, Arte e Tecnologia se fundem nesse espetáculo em que atores-bailarinos interagem com imagens tridimensionais, criadas no computador, como mote para discutir a fecundidade e o ser biológico. E Marte, a viagem, no qual se discute sobre o sistema solar e os planetas, em especial o planeta Marte.

Em 2005 entra em cena o espetáculo $O$ poeta $e$ o vento. Neste, a questão energética permeia a história. É realizada uma reflexão sobre o uso de fontes alternativas de energia por meio de uma fábula sobre o amor e o vento. Escrita por Calixto de Inhamuns e dirigida por Gabriela Rabelo, a peça conta a história de uma cidade imaginária que passa por um problema de falta de luz. O inventor e poeta João e seu amigo Pedro incumbem-se de investigar nas terras da usina geradora de energia os reais motivos da falta de luz sem saberem os perigos que encontrarão. Nesse contexto são introduzidos conceitos de história, ciência, arte e cidadania. 


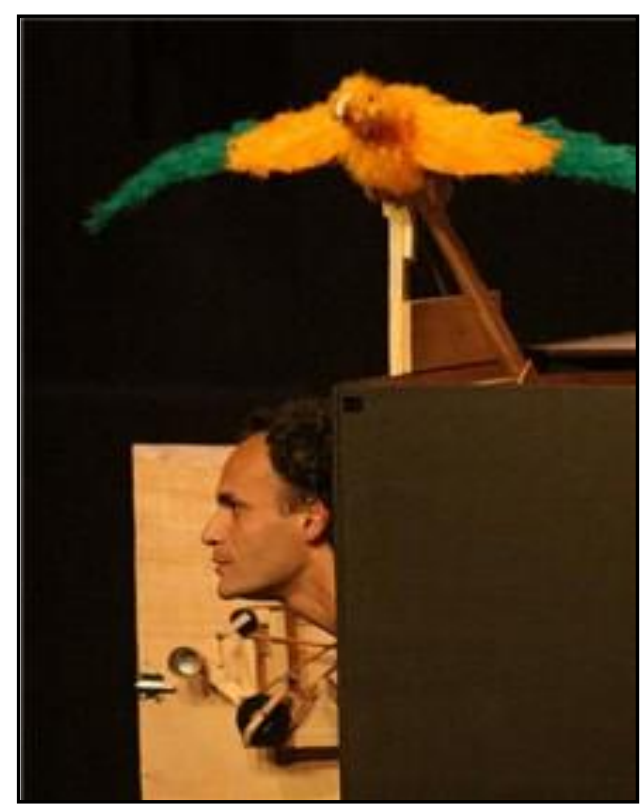

Figura 3.9: Larguem Tudo, Vamos Voar!

No de 2006 o espetáculo Larguem Tudo, Vamos Voar! chega aos palcos pela primeira vez. Sob a direção e autoria de Darci Figueiredo, esse espetáculo resgata a vida, as invenções e os sonhos de Santos Dumont. Tudo começa quando Tereza chega ao local em que deve aguardar por um vôo de helicóptero. Enquanto aguarda, nota uma caixa preta, que ao longo do espetáculo vai revelar diversas surpresas. A primeira delas é o personagem que sai de dentro, o próprio Santos Dumont, que fala sobre sua vida e, em especial, sobre o desejo de voar. A relação entre os dois começa a mudar quando Santos Dumont convida Tereza para um passeio que vai opor a visão de um vôo físico, ligado à dependência externa e às convenções sociais ao de um vôo interno, de desvencilhamento das amarras do cotidiano. Assim, a partir do personagem histórico a peça sugere, metaforicamente, ideias, sonhos e desejos de superar nossas limitações. O espetáculo Larguem tudo! Vamos voar! tem a peculiaridade de ter sido idealizado em conjunto com a criação de uma exposição acerca da avião. Assim, ele se caracteriza como uma encenação que possui um quantitativo de material de registro que possibilita o entendimento da relação que se estabeleceu entre exposição e espetáculo, bem como no que se pretendia privilegiar nesses dois veículos. Nessa pesquisa, realizaremos uma análise mais detalhada desse espetáculo no capítulo de resultados e discussão, já que ele se constitui como espetáculo objeto da pesquisa aqui apresentada.

Após o espetáculo Larguem tudo, vamos voar! a Fábula da Fíbula entra em um período de experimentação e performance teatral que resultou no projeto

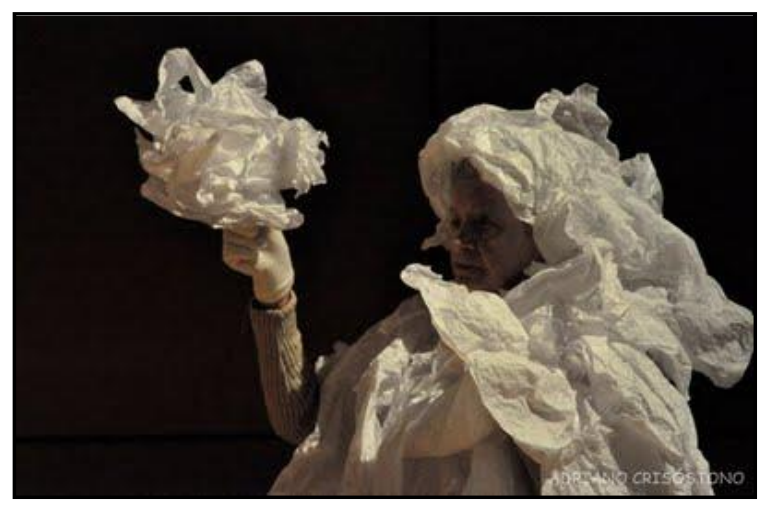

Figura 3.10: O poeta, o rio e a cidade. 
Só com Experiência. Nesse projeto, direcionado à terceira idade, o corpo torna-se o foco na composição cênica. A partir de experimentos realizados nesse projeto e fundamentando-se na ideia de que o corpo revela formas, cores, história, emoções e sonhos, foi criada no ano de 2009 a performance $O$ poeta, o rio e a cidade, sob a direção de Cauê Mattos. Nessa intervenção cênica é proposta uma meditação a respeito do Rio Tiete, com inspiração na poesia de Mario de Andrade.

Além da criação, montagem e produção de peças teatrais com temáticas científicas o Fábula da Fíbula também se propõe a pesquisar e realizar experiências na interface ciência e arte, conjugando preocupação estética, aplicabilidade de conteúdos científicos e verificação de apreensão e aceitação do público (MATOS e SILVA, 2003). Nesse processo, ela tem atendido um público de cerca de 30.000 espectadores ao ano. Dessa maneira, por ter uma tradição de trabalhos na interface Teatro e Ciência, a Cia. Fábula da Fíbula se mostra como sendo o ambiente importante para a realização dessa pesquisa.

\section{5 - Análise dos dados}

Os dados obtidos serão analisados explicitando-se em que medida o objeto desta pesquisa, a saber, o teatro em um museu de ciências, contempla as proposições da alfabetização científica por meio da identificação da presença das categorias teóricas natureza da ciência e da tecnologia, conhecimentos e conceitos básicos da ciência e da tecnologia e relação entre ciência, tecnologia, sociedade e meio ambiente. Assim, procuraremos nos diversos documentos e na fala do coordenador indícios que remetem às proposições da alfabetização científica. 
Resultados e Discussão 
$\mathrm{Na}$ análise apresentada serão explicitados e problematizados os aspectos da alfabetização científica favorecidos pelo espetáculo, fundamentando-se na identificação das informações coletadas e confrontando-as com as categorias teóricas. Também caracterizaremos o teatro enquanto atividade museal, ou seja, em relação com a concepção científica e pedagógica do museu, da temática das exposições e das demais ações educativas desses espaços. Nesse processo, pretende-se desvelar dois movimentos, um mais internalista e, outro, mais externalista. No primeiro, o foco da análise recairá sobre a conscientização e a apropriação da perspectiva da alfabetização científica pelos realizadores dessa atividade (profissionais envolvidos nos projetos), bem como na maneira como essa apropriação é materializada em espetáculo. No segundo, o foco de análise centra-se no teatro como ação de educação e comunicação nos museus, buscando refletir sobre seu papel no contexto das atividades museais e no sentido de se atingir a alfabetização científica. 


\section{1 - Um panorama da relação entre o Teatro e os Museus e Centros de Ciências no Brasil}

Neste tópico serão discutidos os dados encontrados no estudo exploratório, obtidos por meio de questionário. Considerando as 24 instituições que participaram do estudo exploratório dessa pesquisa, realizado com a finalidade de delinear um panorama a respeito das atividades de artes cênicas realizadas em MCC brasileiros, 10 delas declararam não possuir atividade teatrais $(\mathrm{Q} 1)^{13}$. Assim, construiremos uma perspectiva do Teatro enquanto meio de divulgação científica a partir das 14 instituições museais que sinalizaram positivamente quanto à presença de ações de Artes Cênicas entre suas ações.

Tabela 4.1: Instituições respondentes com sinalização positiva. ${ }^{14}$

\begin{tabular}{|l|}
\multicolumn{1}{|c|}{ Instituições } \\
\hline Casa da Ciência - Centro Cultural de Ciência e Tecnologia da UFRJ \\
\hline Catavento Cultural e Educacional \\
\hline Centro de divulgação Científica e Cultural (CDCC-USP) \\
\hline Espaço Ciência Viva \\
\hline Espaço ciência Interativa do IFRJ (ECI) \\
\hline Museu Casa de Benjamin Constant \\
\hline Museu da Geodiversidade \\
\hline Museu de Ciências da Terra Alexis Dorofeef \\
\hline Museu de Ciências Naturais da Universidade de Caxias do Sul / UCS Aquarium \\
\hline Museu de Ciência e Tecnologia de Londrina - Universidade Estadual de Londrina \\
\hline Museu de Zoologia da USP \\
\hline Museu Histórico Nacional \\
\hline Seara da Ciência - Universidade Federal do Ceará \\
\hline Museu de Artes e Ofícios \\
\hline
\end{tabular}

No questionário de coleta de dados delimitamos, inicialmente, as ações envolvendo Artes Cênicas em sete categorias (Q2), a saber, Teatro, Contação de História, Esquetes, Circo, Performance, Dança e Improvisações. Contudo, também havia a alternativa "outro", na qual o entrevistado poderia incluir uma categoria que não

13 A simbologia Q1, Q2 etc. são utilizadas para indicar a questão do questionário que corresponde a essa informação. Assim, Q1 significa a questão número 1 do questionário de coleta de dados.

${ }^{14} \mathrm{O}$ questionário do estudo exploratório não foi enviado à Estação Ciência devido a essa instituição ter sido escolhida para a etapa do estudo de caso. Assim, as informações referentes ao questionários foram coletadas por meio de entrevista, no caso da Estação Ciência. 
havia sido prevista. Na Tabela 2 é apresentada a frequência, por instituição, de cada uma dessas categorias.

Tabela 4.2: Categorias

\begin{tabular}{|l|c|}
\hline \multicolumn{1}{|c|}{ Categoria } & Quantidade de instituições \\
\hline Teatro & 10 \\
\hline Contação de história & 9 \\
\hline Esquetes & 1 \\
\hline Circo & 1 \\
\hline Performance & 2 \\
\hline Dança & 1 \\
\hline Improvisações & 1 \\
\hline
\end{tabular}

A atividade realizada com maior frequência é o Teatro, seguida pela Contação de História e a Performance, com menor frequência aparecem Esquetes, Circo, Dança e Improvisações, cada uma destas últimas presente em somente uma das 14 instituições. Com relação à diversidade das atividades dentro de uma mesma instituição, constatouse que é recorrente a existência de duas atividades concomitantes, em geral a combinação é de Teatro e Contação de História. Apenas uma das instituições declarou realizar quatro das atividades (Teatro, Contação de história, Esquetes e Circo) e cinco declararam realizar somente uma das atividades (Performance, 1; Contação de História, 1; Teatro, 3).

Conquanto a categoria Teatro corresponda à cerca $40 \%$ das atividades realizadas nas instituições colaboradoras (Q2), somente seis delas declaram contratar companhias de teatro (Q3), sendo que as outras oito instituições possuem equipes responsáveis pela idealização, produção e execução dessas atividades (Q4). As pessoas que constituem essas equipes têm formação diversa (Q6), a saber, produção cultural, ator, bibliotecário, técnico em documentação e informação, químico, biólogo, físico, pedagogo, psicólogo, professor de dança, professor de letras, museólogo, diretor, historiador, roteirista, figurinista, costureira, professor universitário, estudante de graduação e estudante de pós-graduação. Dentre esses, os perfis mais frequentes entre aqueles que trabalham diretamente na produção e/ou realização das peças são os estudantes de graduação, os pedagogos e os museólogos, respectivamente. Ainda, três instituições declararam possuir um setor mais diretamente relacionado às Artes Cênicas: a Casa da Ciência com o projeto Palco da Ciência, o Catavento Cultural e Educacional, que conta com a participação de atores no setor de nanotecnologia e o Seara da Ciência (Universidade 
Federal do Ceará), com Grupo de Teatro Científico da Seara da Ciência e Magia da Ciência.

A partir dos dados até aqui apresentados pode-se inferir que as atividades relacionadas às Artes Cênicas têm ocupado um espaço relevante dentro dos MCC, uma vez que cerca de 58\% das instituições consultadas desenvolvem esse tipo de atividade. O Teatro tem sido a expressão mais utilizada e, em geral, as instituições organizam equipes com a finalidade de produzi-lo ao invés de contratar alguma companhia especializada. Assim, o perfil profissional dos sujeitos que desenvolvem essa atividade é bastante variado, sendo caracterizado por um grande número de estudantes de graduação, em geral, sem formação específica em Artes Cênicas.

Essa configuração sinaliza a problemática da formação das equipes para exercerem essas atividades. A possibilidade de um espaço de estudo e aprimoramento é importante, pois ela poderá garantir a melhoria da atividade, favorecendo o alcance de seus objetivos. No caso de a instituição não possuir um grupo de especialistas ou um espaço próprio para essa formação é importante que se estabeleçam parcerias com profissionais da área de Artes Cênicas. Essa prerrogativa é reforçada em Lupetti (2006), que descreve o processo de preparação dos alunos-atores (estudantes de graduação) para a montagem da peça “Além da Lenda", do grupo Ouroboros. Nesse grupo foram realizadas aulas de expressão corporal para o estímulo da criatividade, da sensibilidade, do sentimento de coletividade e da consciência corporal, visando à postura no palco. Também foi realizado um trabalho de voz, visando preparar os alunos-atores para apresentações direcionadas a um número elevado de expectadores.

A periodicidade das ações de Artes Cênicas nos MCC varia entre permanente e eventual (Q8). Oito instituições declararam possuir ações eventuais, sendo estas dependentes da participação em eventos do calendário, das demandas da instituição ou de convites de escolas. Três instituições classificaram as ações como permanentes, com uma regularidade bem estabelecida (sessões de terça-feira à sexta-feira, mensal, durante as férias escolares etc.). Duas instituições declararam possuir atividades tanto eventuais quanto permanentes. Uma instituição não respondeu essa questão. Quando questionados se a função da ação está vinculada à educação ou à divulgação científica $50 \%$ dos entrevistados declaram estar vinculada as duas, $14 \%$ declaram que o objetivo é divulgar a ciência, 29\% declararam que a função é educativa e 7\% (o que corresponde a um entrevistado) não respondeu a essa questão (Q9). As ações que se assumem como sendo 
de divulgação científica se apresentam como tendo a finalidade de despertar o interesse pela ciência; já as que se assumem como ações educativas declaram a proposição de apreensão dos conceitos científicos.

Esse último resultado nos permite identificar, na realidade brasileira, similaridades com a prática do teatro enquanto estratégia de divulgação científica realizada em outros países. As justificativas dadas pelas instituições colaboradoras tanto para classificar as ações como tendo finalidade de divulgação da ciência quanto tendo finalidade educativa nos permite inferir que ambas as ações podem ser classificadas na categoria "teatro como apoio didático", definida Barbacci $(2002,2004)$. Essa categoria contempla ações em que se utilizam da linguagem teatral para promover a aproximação entre o conteúdo científico e o público leigo. Nelas o entretenimento tem a finalidade de despertar curiosidade sobre o mundo da ciência.

A respeito da interação entre as ações de Artes Cênicas e as exposições verificou-se que existe uma relação entre ambas declarada por mais da metade das instituições respondentes (Q11). Sete instituições declararam que o tema da exposição determina o tema das ações, seis relataram que o tema da exposição pode influenciar e somente uma declarou que o tema da exposição não interfere. No caso das exposições determinarem as ações de artes cênicas (50\%) percebe-se um movimento já sinalizado pela literatura, no qual a arte com temática científica surge como evolução das formas de se divulgar a ciência para além dos recursos pictóricos e tecnológicos. Contudo, quando as instituições relatam que a temática da exposição pode influenciar nas ações de Artes Cênicas ou, no caso raro, não influenciam, acabam por revelar a problemática relativa às finalidades educacionais e a articulação entre coleção/objeto, exposição e demais ações educativas nos MCC. Uma das razões desse distanciamento pode ser explicada pelo fato de que muitas vezes os MCC acolhem grupos de teatro externos à instituição. Contudo, as respostas obtidas não permitiram o refinamento da análise.

Por fim, quando questionados sobre a motivação que os levou a desenvolver ações ligadas às Artes Cênicas (Q10 e Q12) os representantes dos MCC declararam que foi a solicitação do público infantil por atividades "diferentes", a sugestão de visitantes no livro de sugestões, a necessidade de despertar nos jovens e adultos o interesse pela ciência, de dinamizar a divulgação científica e de ampliar a comunicação das exposições. Em alguns casos, foi relatado que a atividade teatral surgiu como algo complementar e, aos poucos, foi ganhando espaço até se configurar em um projeto. 
Outros argumentaram que essas ações foram favorecidas pela disponibilidade de grupos teatrais em tratar de temas relacionados às exposições do Museu.

A partir desses relatos pode-se entender que o teatro apresenta-se nos MCC brasileiros como uma convergência de fatores decorrentes de três lugares diferenciados. De um lado, têm-se a necessidade dos próprios MCC e divulgadores em diversificar a forma de comunicação da ciência visando atingir públicos de faixas etárias variadas. De outro, o anseio dos visitantes por atividades diferenciadas. E, finalmente, um ambiente favorável à incorporação do Teatro enquanto linguagem possível dentro dos MCC, decorrente tanto da disponibilidade de grupos de teatro profissionais quanto de sujeitos dispostos a apreender e utilizar essa linguagem.

\section{2 - O Fábula da Fíbula e o Vôo}

Neste tópico discutiremos os dados encontrados na etapa do estudo de caso, realizada com a Estação Ciência, centro de ciências escolhido por sua reconhecida importância na divulgação científica no Brasil.

\section{a) Caracterização do projeto}

A Companhia Fábula da Fíbula é uma das ações do Núcleo de Artes Cênicas da Estação Ciência, que congrega também projetos direcionados à terceira idade, oficinas, seminários e publicações. O Núcleo de Artes Cênicas (NAC) dá sustentação para a pesquisa e trabalhos na interface arte e ciências, na Estação Ciência (EC), apoiado pela Pró-Reitoria de Cultura e Extensão da Universidade de São Paulo. Na ocasião da entrevista o NAC contava com dois integrantes, um estagiário (do campo das ciências da natureza) e o próprio entrevistado, o coordenador. Entretanto, no ano de 2000, início do projeto, contava com oito integrantes. Importante registrar que durante esta pesquisa, em meados de 2012, o Núcleo de Artes Cênicas foi desfeito e a Estação Ciência encerrou suas atividades teatrais.

A ideia de se criar o NAC teve início durante a realização do projeto Em Torno de Zumbi (1995), no qual havia exibição de quadros e painéis. Segundo o entrevistado e coordenador do NAC, na ocasião desse projeto foi sugerido por ele ao então diretor da EC, Ernest W. Hamburguer que fossem inseridas apresentações de dança durante a exposição. Para ele, foi desse contato que germinou o NAC. Mais tarde, em outubro de 1999, em um encontro entre funcionários, técnicos, pesquisadores e artistas, na 
Cooperativa Paulista de Teatro, a proposta do NAC foi consolidada. Naquela reunião foi conversado sobre a disponibilidade do desenvolvimento do teatro dentro da EC. Então, em fevereiro do ano de 2000, Calixto de Inhamuns, diretor do primeiro espetáculo montado pelo NAC, juntamente com Cauê Mattos, retomou a proposta. Dois meses depois estreava a peça $A$ estrela da manhã, uma grande produção de figurino, cenário, atores etc. Com este espetáculo, a companhia viajou por todo o Brasil realizando diversas apresentações e, nos locais em que passava, funcionava como inspiração para o surgimento de grupos de teatro que focalizassem a temática científica. Antes do NAC, só se tinha notícias do projeto Ciência em Cena, do Museu da Vida, FioCruz-RJ, com o espetáculo Mensageiro das Estrelas.

O projeto nasce com o objetivo de abordar temáticas científicas em função do próprio espaço, um teatro dentro de um centro de ciências. Conforme relato do coordenador do projeto, como o espaço se propunha a possibilitar à população em geral o acesso às informações científicas desenvolvidas em centros, institutos e laboratórios, não era possível pensar em um grupo de teatro que trabalhasse com temáticas já exploradas cotidianamente por outros grupos. No entanto, no primeiro espetáculo não se tinha uma ideia muito clara sobre como proceder, sobre qual caminho seguir. Assim, o primeiro espetáculo assumiu a característica, mais fortemente, de meio de divulgar a ciência:

[...] então a gente não sabia pra onde ir ainda. Então foi uma questão de colocar o espetáculo como um veículo mesmo para a divulgação cientifica. Não havia ainda uma pesquisa onde o fazer cientifico... $\mathrm{O}$ fazer teatral se tornasse um fazer cientifico, mas sim, o teatro sendo um meio de divulgar a Ciência (Entrevista Coordenador).

No trecho acima é perceptível a concepção inicial do teatro enquanto instrumento para a divulgação da ciência. Nessa perspectiva, o teatro tornar-se-ia subjugado aos interesses e proposições da ciência ou, melhor dizendo, da divulgação científica. No entanto, nesse mesmo trecho percebe-se o gérmen de uma mudança de postura, há uma perspectiva de que a relação entre teatro e ciência poderia ser mais profícua do que a simples acepção de veículo. Esse tema continua sendo desenvolvido em outro momento:

Apesar de o espetáculo [A Estrela da Manhã] ser bem poético e a gente ter apresentado em vários espaços, não só em Centros e Museus 
de Ciências... Concorreu a prêmios, ganhou! Foi selecionado junto com todos os outros teatros aí do mercado, naquela época. Ele trazia sim... Falava sobre a Babilônia, a Grécia, a Alexandria. Falava sobre as grandes navegações, falava sobre até a Primeira Guerra, Segunda Guerra Mundial, até chegar nos dias atuais. Ele passava por esses momentos históricos, onde havia esses personagens que eram testemunhas destes fatos, mas sempre se questionavam [...]. Então o espetáculo acabou sendo um espetáculo bem questionador, tendo a Ciência não como uma musa, mas como um mote mesmo de questionamento.[...] mas a partir dele a gente viu que tinha possibilidades de não só divulgar a Ciência, mas fazer com que o teatro fosse também visto como um saber, que tem uma técnica, que trabalha com elementos é... Como o corpo, que aí sugere bastante interesse cientifico, e a cada passo que a gente dava a gente buscava concretizar essa ideia. (Entrevista Coordenador).

Ao que parece, o contato do fazer teatral com a ciência resultou na procura de identificação da prática do teatro com a prática científica, com a ciência. Isto é, o reconhecimento de que o teatro também possui práticas resultantes de estudos, de pesquisas e de experimentos (corporais, textuais, de encenação etc.) e que possui objetos a serem analisados (o corpo, o texto, a encenação etc.). E, por conseguinte, constitui-se também como campo de produção de conhecimentos.

Conquanto o caminho a se seguir estivesse sendo descoberto aos poucos e a partir da prática, o relato que segue mostra que houve dificuldades diversas:

Ninguém tinha conhecimento nem fórmulas para fazer acontecer, foi uma pesquisa grande mesmo, interação com outros centros, não só com a USP. Mas com várias outras universidades, verificando produções em vídeo, produções em exposições, até acontecer o primeiro espetáculo. E com o primeiro espetáculo a gente viu o teatro como uma possibilidade de divulgar a Ciência. Então ficava muito caracterizada essa ideia do teatro como uma divulgação cientifica. E aí todos os riscos possíveis, que existiam, de diminuir o teatro à condição só de propagandista da Ciência... Quando que o teatro também é um saber, que tem toda a sua complexidade e possibilidade de interagir de outra maneira com a Ciência (Entrevista Coordenador).

O conflito entre a proposição de divulgar a ciência e a de ser teatro, enquanto obra de arte, aparece no plano de fundo do projeto. Essa suposta dualidade ciência x arte no teatro com temática científica merece maior atenção: $O$ teatro, nesse contexto, deixa de ser arte? Deixa de ser teatro?

Bião (2009) discute sobre a relação da arte com outros campos. Para esse autor, a arte, entendida como fenômeno revelador e constitutivo da vida e do ser humano, 
constrói realidades e sentidos, cujas dimensões não se limitam às proposições (ou intenções) de outros construtos, tais como a ciência, a educação, a política, a religião, o racional da vida cotidiana, dentre outros. Contudo, momentaneamente, ela pode submeter-se a quaisquer desses construtos, reduzindo temporariamente suas dimensões artísticas às dimensões do imaginário e do simbólico dos discursos da ciência, da educação, da política, da religião, do dia a dia etc., sem diluir-se completamente. O que é caracteristicamente artístico poderá sempre persistir, ou seja, a arte pode se servir de todos os paradigmas simbólicos e imaginários, sem se submeter a nenhum deles.

A partir dessa perspectiva pode-se depreender que, qualquer que seja o assunto ou temática presente em uma peça de teatro, este estará em constante relação com a dimensão artística (que persiste). Assim, a ideia de subjugação parece não ser adequada, por ser incompleta, ou simplista. Nesse sentido, e em concordância com Bião (2009), entendemos que o que ocorre, na verdade, é a diminuição da dimensão artística, resultante da pesquisa artística, que envolve estudos, experimentos e técnicas referentes ao trabalho de corpo, de voz, de construção de personagens, de interpretação, de encenação, de produção de texto, de construção de cenários e figurinos etc. Dessa maneira, consideramos ser um equívoco pensar em ausência de arte nas encenações que se propõem a discutir temáticas científicas. A questão, na verdade, é a maneira como a dimensão artística esta presente nessas encenações. Nessa ótica, caberiam questões referentes ao quanto estas encenações situam-se mais próximas de um teatro amador ou de um teatro profissional, admitindo-se como critério para diferenciar essas duas práticas a quantidade/qualidade da pesquisa artística, a dimensão artística.

$\mathrm{O}$ relato prossegue, demonstrando o quanto o contato com a ciência possibilitou uma reflexão a respeito do próprio fazer artístico.

Mas nesse processo todo de... Descobrindo formas, descobrindo pessoas, ideias, comungando com outros grupos... Questionamentos e problemas... A gente chegou [...] a possibilidade de tornar, de fazer ou de registrar e perceber o teatro como um fazer científico também, onde todo o processo teatral está baseado em metodologias, em técnicas e na observação do próprio corpo. Então esse corpo, esse metabolismo em constante movimento, se transformando a cada informação, a cada estímulo. E nessa transformação, nessa condição, há a possibilidade desse estudo. [...] Então o corpo em movimento, não é só um corpo que interpreta um personagem, mas é um corpo onde músculos, ossos... Sinapses estão acontecendo, e com isso, como a gente perceber nesse movimento, a Ciência? [...]Como tornar possível o fazer teatral, em observação, como fazer científico, onde 
um movimento, um gesto, não traga simplesmente a representação emocional de um personagem, mas que ali contenha também um conceito, uma ideia cientifica. [...] E o depois do "Larguem tudo", uma pesquisa muito grande, com o corpo... O corpo ficou sendo prioridade dos nossos estudos. Então daí veio até a pesquisa neurocientífica posterior, que foi depois do "Larguem tudo". E aí nesse estudo do movimento, o estudo do esqueleto, o estudo biológico mesmo. E nesse estudo a ação cênica acontecendo como um processo resultante (Entrevista Coordenador).

Esse "novo" fazer artístico, inspirado no fazer científico e em amadurecimento/formação ao longo dos anos no NAC, pode ser entendido como o que alguns autores denominam de pesquisa artística. Bião (2009) argumenta que não se faz arte sem pesquisa, pesquisa artística. Entretanto, esse tipo de pesquisa, em geral, carece do processo rotineiro de sistematização por meio de projetos e relatórios específicos, de acordo com os modelos e rotinas das áreas de ciência e de tecnologia.

A pesquisa implica em procedimentos de escritura e editoria relativos às informações reunidas, em função de objetivos, sejam eles teóricos, pragmáticos, críticos, tecnológicos ou artísticos, cujo ponto de partida é a elaboração de um projeto, explicitando esses objetivos e descrevendo o processo planejado, suas perspectivas metodológicas, os recursos previstos, o cronograma pretendido, as referências bibliográficas e demais materiais e fontes de consultas previstos. Esses procedimentos complementam-se com a elaboração dos respectivos relatórios e prestações de contas, referentes aos recursos utilizados. Ora, projetos e relatórios não são, necessariamente, parte de um processo de criação artística. O grande desafio, para quem se interessa pela inclusão da criação artística em seus projetos de pesquisa, é a criação de espaço e tempo - nesses projetos - para a suspensão, temporária, do juízo crítico e o livre exercício da criatividade (sempre necessária em qualquer campo de atividade humana, inclusive a ciência), mas da criatividade tipicamente artística. (BIÃO, 2009, p.266).

Existe certa contraposição entre a pesquisa científica e a pesquisa artística (ou pesquisa em arte), no sentido de que está última não teria limitações, ou enquadramentos, em termos de métodos e de apresentação de resultados. Bem como estaria mais direcionada à criação artística e não necessariamente ao registro acadêmico dessa criação. 
[...] pesquisa em arte é qualquer pesquisa que se desenvolva no campo das artes [...] a expressão pesquisa em artes [refere-se] ao trabalho de pesquisa em criação artística, empreendido por artistas que objetivam obter como produto final a obra de arte [...] ou seja, quando o artista também se assume como pesquisador e busca, com essa dupla face, obter trabalhos artísticos como resultado de suas pesquisas [...] ainda persistem muitas dúvidas em relação à pesquisa em arte, questiona-se até mesmo a sua própria existência como tal; muitos artistas e mesmo alguns teóricos [...] entendem que não há sentido em se falar de pesquisa em arte, pois segundo eles, toda arte por sua própria natureza, é pesquisa [...]. (ZAMBONI, 2001, p. 5-7).

A pesquisa artística se diferenciaria da pesquisa científica por estar mais voltada à obtenção de um produto final, a obra de arte - o espetáculo - tendo como meio a criação artística. E não à produção de um conhecimento na perspectiva científica. Nesse contexto, o artista assume a postura de pesquisador e de investigador de si mesmo e de sua arte, e a obra artística é resultado de sua pesquisa. Interessante perceber nesse movimento da pesquisa artística certa similaridade com os resultados no campo da tecnologia. Alguns autores considerados nesse trabalho (vide p. 16 e seguintes) diferenciaram a ciência e a tecnologia devido aos seus resultados, enquanto as pesquisas em ciência estariam direcionadas para a produção de conhecimento científico, as pesquisas em tecnologia levariam à construção de artefatos e produtos tecnológicos, bem como à melhoria desses construtos. Pode-se considerar que, de maneira similar, a pesquisa artística recorre a diversos conceitos e conhecimentos, dentre eles o científico, ajustando-os aos contextos, de maneira a se elaborar um produto, seja um quadro, uma coreografia ou uma peça de teatro. Esse procedimento de apropriação da ciência e de seus construtos teóricos parece constituir a linha de trabalho e de pesquisa artística do NAC ao longo dos anos:

Aí nós fizemos já alguns espetáculos... "A historia do meu corpo". "A historia do meu corpo" onde um ser inerte no chão só respirando... Estava ali... A partir daí ele cria movimentos, vai se transformando... Aí a respiração começa a ser mais intensa e nessa movimentação intensa ele desloca alguns membros, alguma parte do corpo. E nesse deslocar-se, começa a se deslocar pelo espaço. Ao se deslocar rastejando pelo espaço ele vai criando deslocamentos com apoio. Um deslocamento com apoio vai transformando do nível baixo para o nível médio, então já ganhando espaço no corpo, e aí levanta um pouco o corpo. Desse movimento dos apoios... Aí quatro apoios, vai pra três, vai pra dois, no "dois" começa a trabalhar a coluna. E o 
deslocamento, já em várias possibilidades. Com isso ergue-se o corpo. Fica totalmente ereto. E aí uma visão de horizonte, uma visão de outras explorações. [...] É um espetáculo onde tem, um pouco esse estudo do movimento, mas também um estudo do próprio processo, de evolução dos animais. Desde uma única célula lá, contida em si mesmo, pra buscar espaço, transforma-se e o olhar, o horizonte, e desloca-se por todas as possibilidades posteriores (Entrevista Coordenador).

A relação com a ciência foi se estabelecendo desde o olhar sobre o próprio ator (no caso do processo em estudo um olhar fisiológico) até à utilização da ciência enquanto metáfora para a criação artística.

Entrevistador: Aí você deu quase que uma invertida, a Ciência virou uma metáfora para a construção artística, nesse processo?

Coordenador: Exato, é isso mesmo.

Entrevistador: Ela tá implícita no processo de criação... E como foi formatada a ação?

Coordenador: E foi nesse processo que a partir do "ok, formulamos isso. Vai chegar para o público?’. E nós apresentamos. E o resultado... A gente não explicava nada... Todo mundo já falava o que estava acontecendo: "Nossa... Você contou... A gente viu a história do movimento, a gente viu a história da evolução das espécies!".

Entrevistador: Tiveram relatos assim, é?

Coordenador: Sim.

Entrevistador: da evolução das espécies?

Coordenador: Tivemos.

Entrevistador: Porque não... Não tem falas né?

Coordenador: Não tem falas!

Entrevistador: É corpo?

Coordenador: É corpo, só corpo.

Entrevistador: Legal.

Coordenador: Então aí. Como o teatro, a própria ação cênica ser Ciência? Tem essa questão que o próprio artista vai entender isso pessoalmente, porque no processo de construção do seu espetáculo, do seu personagem, se ele não investigar, não vai acontecer nada, vai ser fraco, frágil, medíocre. Então para acontecer, ele precisa deixar claro que a pesquisa dele foi forte também, foi consistente. Então aí o processo científico está acontecendo, com o próprio realizador da obra. E depois disso, ao colocar isso em movimento, ao colocar isso em cena, como resultar isso em Ciência, direto, sem explicação? Aí veio esse movimento e essas conclusões todas. Então nós estamos percebendo, em forma de conclusão mesmo, de reflexão atual, essa possibilidade de cada vez mais tornar a ação cênica uma ação científica, principalmente sobre o olhar da platéia, que a platéia ao 
olhar determinada ação não perceba simplesmente o animal, o pesquisador, o personagem, mas que ali esteja imbuído de conceitos, de conteúdos científicos. Essa é a nossa pesquisa atual (Entrevista).

Novamente a pesquisa artística aparece como sendo o passo essencial para que o espetáculo possa ser construído. No turno 39 o entrevistado sinaliza a situação atual da pesquisa artística desenvolvida pelo NAC.

"A história do corpo" ao trabalhar [...] com o pessoal da terceira idade. Então essa ideia, do corpo, do estudo, do fazer teatral como fazer cientifico, está acontecendo com esse grupo agora. [...] Então essa é a ideia, de trabalhar o corpo. E todas elas fizeram uma pesquisa muito grande do corpo, trabalharam é... Sistema esquelético, muscular, todos os órgãos. Fizeram um trabalho sobre uma determinada parte do seu corpo ou órgão e esboçaram isso. E transformaram isso em cenas. Teve essa pesquisa e o resultado depois é esse espetáculo (Entrevista Coordenador).

A partir das falas do coordenador do NAC percebe-se uma evolução da pesquisa artística a partir do contato com temáticas científicas. Em um primeiro momento o conhecimento sobre o fazer ciência levou à reflexão sobre o fazer teatro. E, como uma maneira de aproximar teatro e ciência, foi estabelecida uma dinâmica de adotar aspectos do fazer científico para o fazer teatral. O conhecimento sobre a natureza da ciência termina por influenciar e criar uma nova postura frente aos métodos, as práticas e as maneiras de se pensar o teatro. Isso resultou na adoção da pesquisa, do debate, do registro e de um olhar questionador. Essa nova postura levou o NAC a se focalizar em uma pesquisa a respeito do corpo na ação cênica, na qual o personagem é visto como um conjunto de gestos/movimentos, que tem sua origem no corpo, fisiologicamente falando. Assim, a construção da ação cênica passa a ser permeada, necessariamente, pelo estudo da fisiologia humana. Ao mesmo tempo em que processos fisiológicos passam a constituir o material para a ação cênica, também passam a constituir as temáticas e metáforas para a encenação.

Percebe-se na pesquisa artística adotada pelo NAC uma estrutura semelhante à desenvolvida na peça didática de Brecht (PAVIS, 1996; KOUDELA, 1991). Os procedimentos de construção dos personagens e do próprio espetáculo em si favorecem a aprendizagem em ciências dos atuantes. Isto é, os primeiros a passarem pelo processo de conhecimento sobre ciência, de alfabetização científica, são os próprios atores. E, assim como na peça didática, estes é que poderão ter os conhecimentos científicos mais 
fortemente construídos e aprofundados. No entanto, adotando a perspectiva de que todo teatro possui um elemento de didatismo, pode-se considerar que, potencialmente, os espectadores podem se beneficiar quanto aos conhecimentos e discussões sobre ciência presentes no espetáculo.

Conquanto tenhamos construído perguntas no roteiro de entrevista objetivando a explicitação da conscientização das proposições da alfabetização científica, não foram obtidos dados nesse sentido. Na realização da entrevista percebeu-se o desconhecimento desse campo teórico de referência na educação em ciências. Assim, não constatamos uma perspectiva de alfabetização assumida pelo projeto. No entanto, alguns trechos da entrevista nos fornecem indícios a repeito de como o projeto é visto pelo coordenador no cenário da educação em ciência, e isso nos permite inferir como o projeto se relaciona com as proposições da alfabetização científica:

Eu poderia até, num determinado momento, colocar (uma equação), mas não ficar restrito àquela colocação, como se aquela colocação fechasse toda uma ideia. E todo o conjunto de ideias selecionadas, produzidas para o espetáculo, se resume numa equação. Não! A equação, a equação seria o elemento pra explorar todas essas outras possibilidades. Eu estou falando isso porque no Einstein do Carlos Palma, ele tem uma lousinha. E ele faz a equação. E claro que ali, aquilo é só um detalhe. Ele até escreve aquilo rapidamente, não dá muita importância para aquilo. A vida é maior que aquilo. Isso é muito interessante, porque a vida é maior que a Ciência. Então, a Ciência faz parte, é um elemento importante. E ela pode até revelar-nos, nos tornarmos mais conscientes dessa potência, dessa coisa maior que é a própria vida. Mas a vida é maior que a Ciência. (Entrevista Coordenador)

$\mathrm{Na}$ fala supracitada o coordenador evidencia a proposta de que os conceitos e conhecimentos científicos devem ser abordados nos espetáculos com a finalidade de auxiliarem mais na compreensão do que seja a ciência do que para que sejam profundamente compreendidos. Fica patente na fala que a função primeira seria a de veicular a percepção de que a ciência é parte da vida, é uma maneira de promover uma maior conscientização a respeito da própria vida. A defesa desse posicionamento esta atrelada a uma concepção de público e de necessidade de formação em ciências, conforme relatado a seguir:

[...] o público que vem aqui, eu não sei se vai ser cientista, não sei se vai ter essa obsessão pelo conhecimento. E também não sei se é tão 
interessante ele sair daqui e falar: Não! É... A água é $\mathrm{H}_{2} \mathrm{O}$. O ar é o oxigênio (risos). [...] Não sei se é tão interessante isso, mas, principalmente, é saber que há sim possibilidades de conhecimentos sobre tudo isso. Aí, sim, aí a gente coloca ele numa situação que eu acho bem interessante. De saber que o mundo pode se revelar pra ele. E a partir daí ele ter mais consciência sobre tudo isso. Se sentir mais dentro disso, se sentir incluído, se sentir como uma pessoa que pode interferir, como uma pessoa que pode ser protagonista, como uma pessoa que pode dividir conhecimento, que pode, na busca, depois dividir. Porque uma pessoa que pode assumir com mais ênfase, com mais veracidade, com mais discernimento a sua cidadania, não vai ser uma pessoa que está sujeita a qualquer ideia, a qualquer pensamento. Ele vai ter, com certeza vai ser uma pessoa, que: “_ Não, "peraí”, opa! Se determinada situação lá, que eu vi, chegou a partir né, dessa maneira, então aqui também deve ser isso! Então vamos olhar um pouco isso aqui, observar e ver se é por aqui mesmo?" (Entrevista Coordenador).

Uma vez que não se sabe qual a demanda de formação do espectador o projeto assume a proposição de fornecer um repertório mínimo de conceitos e termos científicos necessários para o entendimento das situações em que assuntos da ciência estão envolvidos. Entretanto, o objetivo final, e principal, é o estímulo a liberdade intelectual dos sujeitos e a instrumentalização com procedimentos e posturas que possam auxiliar nos processos de tomada de decisão. Esse posicionamento é reforçado em outro momento:

[...] Então o espaço da Estação Ciência, eu vejo dessa forma, que é um espaço, como do Teatro e Ciência, onde você sugere situações para o despertar, para o tomar o gosto, pelo estado de consciência sobre o cotidiano, pelo estado de possibilidade dos mistérios se revelarem. E aí cria esse desafio gostoso, que todo ser humano gosta. [...] Então o que a gente vê é isso, e é isso que é interessante. Não sei se é tão interessante sair daqui com essa ideia do $\mathrm{H}_{2} \mathrm{O}$ e tal. Porque aí é muito, é restringir demais, fica muito pequeno... Quando ele pensa no todo e busca essa interação com o todo, sabendo que há essa possibilidade, aí sim, aí o efeito educacional está mais contemplado. [...] Então é isso, o que eu acho muito importante mesmo, nesse processo todo, que não é um centro formal de educação, não é uma faculdade, não é uma escola, não é um ensino médio. Nada disso. É justamente colocar as pessoas nessa situação de curiosidade, de buscar se conscientizar, de buscar o conhecimento, de buscar determinada situação que revele o quanto ele pode ainda avançar. Esse lugar é que é interessante para, acontecer um espaço como a Estação Ciência, como o teatro, porque no teatro são duas horas no máximo. O quê que a pessoa vai aprender exatamente? (Entrevista Coordenador) 
Nesse último trecho a responsabilidade pela aprendizagem conceitual em si é atribuída à educação formal, ficando a encargo do museu e do teatro com temática científica possibilitar a ampliação da compreensão da ciência para além desse aspecto conceitual. Assim, percebe-se que a proposta de alfabetização científica implícita no projeto contempla melhor a dimensão natureza da ciência, em especial por privilegiar o estímulo à liberdade intelectual, e a dimensão relação entre ciência, tecnologia, sociedade e meio ambiente, por focalizar a relação da ciência com a vida e a instrumentalização de procedimentos para a tomada de decisão. A dimensão conceitos e conhecimentos básicos da ciência e da tecnologia é contemplada em menor intensidade, uma vez que os conceitos e conhecimentos científicos e tecnológicos seriam abordados como ferramentas para o entendimento da ciência como sendo parte da vida.

\section{b) A peça}

A peça teatral selecionada para ser analisada é intitulada Larguem tudo, vamos voar! Ela estreou em 11 de agosto de 2006, realizando duas temporadas no Teatro Ernst W. Hamburguer (da Estação Ciência), tendo sido apresentada posteriormente em diversos locais. Conforme ficha técnica, a equipe era constituída por Darci Figueiredo (iluminação, cenografia, autoria do texto e direção), Cauê Mattos e Luanna Jimenes (atores), Cauê Procópio (música original, produção musical e trilha sonora), Luiza Albuquerque e Cauê Procópio (produção musical e trilha sonora), Carlos Fernando Pedroso (operador de som e luz), Alexandre Gomes Amorim (adereços), Miguel Paladinho (cenotécnico), Hernandes de Oliveira (figurinista), Carlos Fernando Pedroso (assistente de iluminação), Cláudio Gomes (produtor executivo), Eduardo Sardinha (fotógrafo), Michel Sitnik (assessor de imprensa), Roseli de Deus Lopes e Maria Inês Nogueira (consultoria científica), Wats (criação gráfica e site) e Alex Faro, Sophie Mere, Xico Rafaeli, Michel Sitnik, Cristiam Procópio e Oscar Ulisses (vozes em off).

O contexto de surgimento da peça foi a comemoração do centenário do voo do 14 Bis:

Tinha é... 2006 foi o centenário do voo do 14 Bis, então tinha essa ideia, que estava no Brasil inteiro, comemorando o voo do 14 Bis e nós entramos com um projeto junto ao $\mathrm{CNPq}$, que foi aprovado. Participamos no comitê dos 100 anos do voo do 14 Bis. Nessa veio a 
possibilidade mesma de realizar esse espetáculo. Então foi a partir do centenário. (Entrevista Coordenador).

O projeto submetido ao CNPq pela Estação Ciência foi nomeado de $A$ Invenção de Santos Dumont: os princípios que permitiram a construção do 14-BIS, sob a coordenação da Profa. Dra. Roseli de Deus Lopes. Nesse documento é anunciado que se pretendia realizar três ações: a criação de uma exposição temática e interativa, a itinerância dessa exposição por outras regiões do país e a montagem do espetáculo Aquele que viu o que ainda veremos (nome provisório do espetáculo aqui analisado). Durante um ano o espetáculo teatral ficou em cartaz na Estação Ciência, em concomitância com a exposição prevista no projeto. A escolha pelo nome Larguem tudo! Vamos voar! se deu posteriormente à aprovação do projeto. Ele remete à fala dos balonistas, dita no momento em que as amarras devem ser soltas para que o balão voe.

O espetáculo conta a história de uma mulher que aguarda por um voo de helicóptero. Na sinopse da peça se lê:

Tudo começa quando Tereza chega ao local em que deve aguardar por um voo de helicóptero, novidade para ela. Enquanto aguarda, Tereza nota uma caixa preta, que ao longo do espetáculo vai revelar muitas surpresas. A primeira delas é o personagem que sai de dentro, o próprio Santos Dumont, que fala sobre sua vida, suas invenções e seus sonhos, em especial, o desejo de voar. A relação entre os dois começa a mudar quando Santos Dumont convida Tereza para um passeio que vai opor a visão de um voo físico, ligado à dependência externa e às convenções sociais (simbolizado no helicóptero) ao de um voo interno, de desvincilhamento das amarras do cotidiano, um voo de liberdade. Aos poucos, Tereza vai sendo conquistada pelo inventor e cedendo ao convite. A caixa que aparece desde o início acaba se revelando um rico laboratório, um atelier, um baú de invenções, representando simbolicamente o ímpeto criativo de Santos Dumont. Assim, a partir do personagem histórico, a peça sugere, metaforicamente, ideias, sonhos e desejos de superar nossas limitações... "mesmo que seja com asas de galinha" (Texto do portfólio).

A proposição do voo subjetivo, interior, de libertação das amaras cotidianas é transposta em imagens no panfleto de divulgação do espetáculo. Nele se percebe vultos que remetem à atitude de voar. 


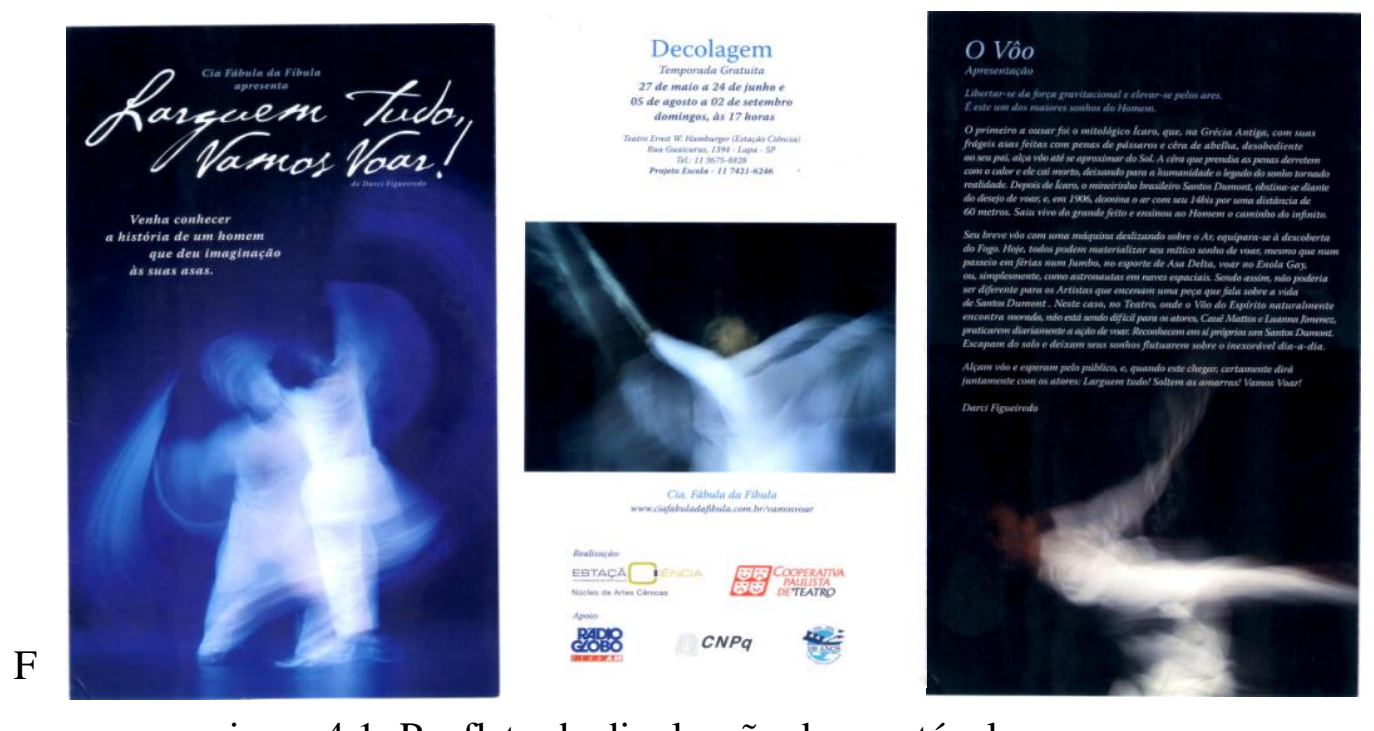

igura 4.1: Panfleto de divulgação do espetáculo.

\section{b.1) 0 texto da peça}

O texto da peça não anuncia objetivamente nem o lugar e nem o momento em que a história acontece. Há diversos indícios de tempo e de espaço. O que se percebe, na verdade, é uma modificação desses elementos de acordo com a ação das personagens.

O texto disponibilizado para essa análise não é dividido estruturalmente em cenas ou atos. A escrita é contínua, sendo separada pelas rubricas de cena. Estas são utilizadas para indicar ao leitor as ações a serem realizadas, explicitar as emoções e o comportamento das personagens ou indicar a interpretação, conforme se percebe pelos trechos que seguem:

Palco negro. O publico entra. No palco um casulo coberto por capa preta feita em papel de seda. Uma mulher, vestida de forma elegante, está sentada numa cadeira observando o casulo coberto. Ouve-se que, dentro do casulo, alguém constrói algo. Usa serrote, martelo, prego etc... A mulher se levanta, por curiosidade. Começa a puxar a capa de papel. No seu primeiro movimento os ruídos de dentro do casulo são interrompidos abruptamente. A mulher observa este movimento e silencia por alguns segundos. Começa a puxar a capa. Com o movimento do papel, sorrateiramente, ouvimos o som de uma escola de samba. Explosiva. Black -out. O volume da musica sobe de acordo com a retirada da capa que revela uma caixa preta. A caixa é iluminada, internamente, por lâmpadas de brilho intenso. A mulher enrola-se na capa de papel de seda preto e samba. A música é 
interrompida no seu ápice e de forma abrupta. Um homem de dentro da caixa diz: Larguem Tudo! Soltem as amarras! Vamos voar!

A mulher senta-se novamente na cadeira. $\mathrm{O}$ homem que estava dentro da caixa mostra a cara por uma pequena janela (Texto da peça, p.1).

A mulher mostra-se impaciente e não responde. Ele prossegue (Texto da peça, p. 2).

Ele - (tranqüilamente, quase rindo) Ah, que soberbo! (Texto da peça, p. 5).

A trama se desenvolve por meio de dois personagens, nomeados de Ele e Ela. Quase não há indicação de caracterização das personagens no texto. No que se refere a Ela encontra-se apenas a rubrica uma mulher, vestida de forma elegante [...] (Texto da peça, p.1). Quanto a Ele, não há qualquer informação de referência.

O texto apresenta os elementos clássicos dos textos dramáticos: personagens, conflito e diálogo (PAVIS, 2008). O conflito que movimenta a peça gira em torno dos desejos antagônicos dos personagens Ela e Ele. Enquanto Ela deseja o voo físico com o amigo Antônio, Ele deseja levá-la para um voo subjetivo. Ao longo do texto, ele se mostra como um obstáculo a ser transposto no momento que se nega a fornecer informações a respeito da localização do heliponto e, ao contrário, procura seduzi-la para que alce o voo que ele propõe. A estratégia de sedução passa por convencê-la de que Ele é Santos Dumont, de que sabe voar e de que possui os aparatos necessários. Ao longo do espetáculo, devido a não chegada do helicóptero e ao vínculo de amizade e de cumplicidade desenvolvida com Ele, Ela desiste do helicóptero e aceita voar com Santos Dumont.

Os diálogos acontecem entre os dois personagens, assumindo nuances variadas e possibilitando identificar inclusive a existência de monólogos ao longo do texto. A comunicação que se estabelece é de igualdade, não se verifica a subordinação de um personagem ao outro, ou a explicitação de relação de classe. Contudo, além de trazerem informações a respeito da temática da peça, os diálogos evidenciam as transformações do vínculo psicológico entre as personagens, ao longo do texto. O início do texto é marcado pela existência de três pequenos monólogos técnicos (narrativos) e no decorrer do texto identifica-se a repetição de pequenos monólogos (narrativos e líricos) e de 
diálogos de enfrentamento e de reconciliação. Como se percebe-se nos trechos que seguem:

Ele - Eu sou Santos Dumont (em francês e português)

Nasci na fazenda Cabangu, em Minas Gerais, no ano de 1873. .Com 5 anos de idade fui morar numa fazenda de Arindeúva, perto de Ribeirão Preto, no Estado de São Paulo. Meu pai, Henrique Dumond... meu pai... tinha cinco milhões de pés de café nessa fazenda...ele mandou construir uma estrada de ferro de $90 \mathrm{~km}$, da fazenda até a central da Mogiana, para escoar a produção do nosso café. Eu adorava a fazenda, gostava das máquinas, dos tratores. Com seis anos eu já guiava um trator. Eu não gostava da lavoura, gostava mesmo era de ficar observando, horas e horas, os pássaros, gostava de subir em árvores, na copa das árvores, gostava de soltar pipa. Ficava pensando aqui na minha cachola que, as asas do pássaros batiam movidas a um motorzinho. Eu era doido mesmo, vivia dizendo que uma hora eu inventaria uma maquina que me fizesse voar, por isso que eu adorava montar e desmontar motores, ver as máquinas do preparo do café funcionando. Com doze anos eu já ficava no lugar do maquinista na estrada de ferro do meu pai, era uma locomotiva Baldwin, Baldwin (Monólogo narrativo, Texto da peça, p, 1-2).

Ele - Ícaro caiu no mar. Eu, Santos Dumont, certo dia sentindo muito os meus ossos doendo dentro de mim, como se estivessem se evaporando, se metamorfoseando em asas..quis me mudar para perto do mar....eu sonhava que meus ossos estavam se transformando em asas... fui morar bem perto do mar fui para o Guarujá... gostava de ficar vendo $\mathrm{o}$ ir e vir das ondas... minhas asas foram ficando encharcadas... meus ossos ardiam em brasas... Sons de pássaros lancei-me em direção ao Sol...(congela o grito de morte) (Monólogo lírico, Texto da peça, p. 12).

Ele - (em francês) Se a senhora quer falar dessas coisas, eu prefiro me retirar, vou trabalhar.

Ele entra na caixa. Começa a trabalhar. Os helicópteros se aproximam novamente. A luz cai e se movimenta. Ele sai para ver. A mulher recolhe tudo e espera. Ela acena para o alto. Ele olha para ela. Os helicópteros se afastam novamente.

Ela chora silenciosamente. Ele vai até ela com um lenço.

Ela - Acho que o Antonio se esqueceu de mim. Eu queria tanto voar um pouco!

Ele oferece seu lenço branco.

Ele - Perrmita, Madame.

Ela aceita.

Ele - Será que era ele? (olha para cima) 
Ela - Acho que não, o barulho de agora era assim (faz o som) e o Antonio me disse que o barulho seria assim (faz o som).

Sabe?! É um sonho antigo que eu tenho, voar, voar de avião, de helicóptero, de qualquer coisa, mesmo que fosse para implantar umas asas eu faria, só para poder voar ! Não implantam de tudo hoje em dia? Então!?, quero implantar uma

asa ! Mesmo que fosse com penas de galinha, é, é uma grande idéia para pesquisa: implantar asas. Já pensou?! Eu, pela Av. Paulista, voando? SP

Silencia.

Ele canta uma música suave.

Ela se recompõem.

Ela - Me desculpa senhor Santos Dumont ! (em francês)

Ele sorri. Ele se afasta, silenciosamente. Ouvimos trechos dos vôos dos flamingos. Trechos suaves (Diálogo enfrentamentoreconcialiação, Texto da peça, p. 8-9).

A dimensão biográfica do texto, explicitada nas de diversas falas do personagem Ele, apresenta um Alberto Santos Dumont, nascido no ano de 1873, em Cabangu, interior de Minas Gerais, e criado em uma fazenda em Arindeúva, próximo a Ribeirão Preto, São Paulo. Filho de Henrique Dumont e Francisca de Paula Santos, irmão de Henrique, Maria Rosalina, Virgínia, Luiz, Gabriela, Sophia e Francisca. Na infância foi ensinado a escrever por sua irmã, Virgínia. Depois estudou em colégios em Campinas e em São Paulo. Gostava de passar as férias na fazenda, junto de sua mãe e irmãos. Interessou-se pelo voo e iniciou estudos sobre balões. Passou boa parte de sua vida estudando balões em Paris, França, com o auxílio de especialistas em física, química, eletricidade e mecânica. Criou vários balões, um deles foi chamado de balão Brasil, considerado o menor balão já feito. Mais tarde, criou o primeiro avião, o 14 Bis, que alçou voo em 1906, na Praça Bagatelle. Perdeu pessoas queridas ao longo da vida, tais como amigos e professores no acidente com o hidroavião em 1927, na Baía de Guanabara, e, mais tarde, seus pais. Em suas empreitadas e invenções foi financiador, engenheiro, operário e piloto. Sem formação acadêmica no campo da engenharia, é caracterizado como homem que luta com tenacidade e experimenta até alcançar o que deseja. Teve um final de vida trágico, cometendo suicídio por ver sua invenção sendo utilizada para lançar bombas e rajadas de tiros, matando pessoas. Alguns exemplos de falas biográficas são:

Ele - (enquanto passeia dentro da caixa) (música suave, Zen) Minha irmã, Virgínia, foi quem me ensinou a ler, me iniciou nos estudos. Depois eu fui estudar em Campinas e depois no colégio em São 
Paulo. Mas eu gostava mesmo era de passar as férias na fazenda, com minha mãe....minha mãe...meus dois irmãos (Texto da peça, p. 3)

Ele - Em uma das minhas primeiras viagens à Paris, meu pai, Henrique Dumont, meu pai... Ele se sentiu mal no porto do Rio de Janeiro, no momento de partirmos. Eu quis ficar com ele, mas ele insistiu para que eu seguisse viagem e ainda falou: vai filho, vai para Paris e torne-se um homem. .. alguns meses depois eu recebi uma carta, falando que meu pai havia falecido... Pai!, pai, pai!... Minha mãe, sentindo muito a falta do meu pai... ela ficou na fazenda... resolveu visitar minhas irmãs em Portugal. Na casa das minhas irmãs, em Portugal, sentindo a falta do meu pai, ela... ela... se enforcou! Eu, em 1932, em São Paulo, vendo a minha invenção sendo usada para matar brasileiros, sendo usada para atirar bombas e rajadas de tiros... eu não suportando esse absurdo, eu... (Texto da peça, p.10).

O texto da peça retrata Santos Dumont como sendo um homem comum. E ressalta o fato de ele não ter cursado faculdade de engenharia, como seus irmãos. Ao invés disso, preferiu realizar estudos independentes, de maneira autônoma, tendo como foco o objeto de curiosidade que perseguiu desde sua infância: o voo. O resultado foi uma formação não formal que o possibilitou criar balões e ser o inventor do avião. A imagem que se tem aqui é bastante diferente da tradicional imagem do homem de ciência: acadêmico, taciturno e isolado em suas experimentações. As características apontadas pelo texto como sendo causas da inventividade de Dumont são o encantamento por um fenômeno, a curiosidade em desvelar seu funcionamento e a tenacidade em desenvolver estudos e experimentos para reproduzir fenômenos. Esses três elementos aparecem como sendo o caminho para se tornar um homem de ciência. Percebe-se também uma habilidade ainda hoje bastante exigida de tecnólogos e acadêmicos, a multifuncionalidade. Com respeito às suas próprias produções, conforme relata o espetáculo, Dumont foi financiador, engenheiro, operário e piloto. Essa dinâmica guarda bastante similaridade com a vivência dos pesquisadores brasileiros.

Apesar de não explorar a temática amplamente, dois trechos da dimensão biográfica fornecem indícios sobre a relação entre ciência, tecnologia e sociedade:

Ele - Foi meu pai quem me levou à Paris, pela primeira vez. Lá, eu vi os dirigíveis, fiquei louco, queria ficar em Paris, morando com meus primos, ficar estudando em Paris. Quis voar num dirigível, mas era muito caro, quase dois mil francos, eu não tinha esse dinheiro. Voltei 
com meu pai para Arindeúva. Meu pai... (se emociona)...não agüentou me ver triste . Ele me chamou e me disse; "meu filho, vá para Paris, quando você quiser, lá, com o auxílio de nossos primos, você encontrará um especialista em Física, Química, Mecânica, Eletricidade, estude essas matérias e não se esqueça de que o futuro do mundo está na Mecânica. Você não precisa pensar em ganhar a vida, com venda da fazenda, você tem o necessário para viver " (Texto da peça, p.11, grifo nosso).

No trecho acima é estabelecida uma relação entre as chamadas ciências básicas e a tecnologia, ressaltando a interdependência entre esses dois campos e a necessidade de diálogo entre eles para que algo de novo pudesse ser produzido. Esse movimento se repete no momento em que o texto relata o desgosto e a inconformidade de Dumont ao ver seu produto tecnológico sendo utilizado para fazer mal às pessoas.

Ele - Em uma das minhas primeiras viagens à Paris, meu pai, Henrique Dumont, meu pai... Ele se sentiu mal no porto do Rio de Janeiro, no momento de partirmos. Eu quis ficar com ele, mas ele insistiu para que eu seguisse viagem e ainda falou: vai filho, vai para Paris e torne-se um homem. .. alguns meses depois eu recebi uma carta, falando que meu pai havia falecido... Pai!, pai, pai!... Minha mãe, sentindo muito a falta do meu pai... ela ficou na fazenda... resolveu visitar minhas irmãs em Portugal. Na casa das minhas irmãs, em Portugal, sentindo a falta do meu pai, ela... ela... se enforcou! Eu, em 1932, em São Paulo, vendo a minha invenção sendo usada para matar brasileiros, sendo usada para atirar bombas e rajadas de tiros... eu não suportando esse absurdo, eu... (Texto da peça , p.10, grifo nosso).

Nesse último trecho, o texto da peça exemplifica como um produto do intelecto humano, criado a partir da curiosidade em conhecer a natureza, pode ser apropriado para finalidades diversas, ora resultando em benefícios e ora resultando em malefícios para o ser humano. Esses dois trechos contemplam discussões localizadas na categoria teórica relação entre ciência, tecnologia, sociedade e meio ambiente, uma vez que fornecem elementos para a discussão acerca das consequências e dos impactos da ciência e da tecnologia para a vida em sociedade.

A face humana de Dumont é apresentada em trechos marcados por colocar em evidência os gostos, sonhos, desejos e sentimentos de Dumont. Eles retratam o menino que gostava de observar os pássaros, de subir em árvores, de soltar pipa. E pensava que as asas dos pássaros batiam movidas a um motorzinho. Esse menino acreditava que uma 
hora inventaria uma máquina que o faria voar. Montava e desmontava motores na tentativa de aprender o seu funcionamento. Gostava dos prédios altos, de ver as nuvens passando. Ficava impressionado com os balões e os dirigíveis. Quando adulto, decidiu não cursar engenharia para investir seu tempo em seu sonho: elevar-se pelos ares.No trecho que segue é apresentado o relato de uma dimensão do "experimento" que não aparece nos periódicos, nos artigos científicos. Um relato abordando a dimensão afetiva do experimentador na ocasião em que realiza o próprio experimento:

Ele - O nada, o vazio... E eu deslizando pelo ar. Sabe madame, a minha primeira experiência com o voo foi algo que jamais se repetiu. Eu perdi completamente a noção de tempo e espaço e ao estar lá em cima, no céu, entre as nuvens, sentindo um vácuo, um vazio dentro do meu corpo, eu olhei para as casinhas enfileiradas lá embaixo, que mais pareciam brinquedos de criança. Foi uma experiência... Foi uma sensação sem igual, que jamais se repetiu madame (Texto da peça, p.4).

Por meio desse relato fictício o texto abre a possibilidade de se enxergar no experimentador não só a expertise, o arranjo dos conceitos científicos ou dos conceitos tecnológicos, a técnica ou o método, mas também o prazer e a satisfação pessoal em fazer ciência, em criar tecnologias. Os trechos também ressaltam a característica pessoal de persistência em se alcançar um sonho.

Ele faz várias tentativas de voo. A cada queda ele decide seguir com seus intentos, obstinadamente. Loucamente, sem poupar esforços. Fala dos acidentes.

Ele - Eu sempre sofri muitos acidentes, mas eles nunca foram motivo para eu desistir. Muito pelo contrário, eles sempre foram o motivo para eu resistir. Para realizar o meu sonho, o sonho de voar (Texto da peça, p.11).

Por fim, duas características ainda são atribuídas a Dumont, um adulto acriançado, no sentido de se deixar tocar pela natureza, de se surpreender e de se encantar. Sensação vivenciada por qualquer criança na descoberta do mundo. E o desejo de querer mais, de conhecer mais, de descobrir mais, de inventar mais:

Ele - Hoje, eu dou voltas pelo céu de Paris! Sou conhecido em todo o mundo. (silencia) Agora quero ir até as estrelas mais distantes, quero ir até a Lua, quero andar no solo de Marte, quero voar por galáxias. , mas, por todo lugar por onde eu passar, se eu tiver viver sempre com os pés no chão, eu logo deixarei esse lugar, quero me libertar, para 
sempre, da Lei da Gravidade, quero dominá-la, voar por aí, sem barreiras, sem fronteiras. Quero que todos voem comigo, que todos naveguem pelo ar, com seus próprios braços e com suas próprias pernas, com leves movimentos, com o sonho liberto. Pensamentos livres, vida livre! Não quero ter, possuir balões, dirigíveis, aviões, quero apenas voar. Eu não inventei o 14bis para ser um proprietário. Ah! Quando estou deslizando pelo ar vejo a Terra e vejo meu coração. Quanto mais alto voo, mais linda é a Terra. É como olhar para um aconchegante e distante berço da sua infância. A Terra é assim, um berço aconchegante. Ver os pássaros, voar com eles, voar ao lado deles. É como ver um grupo de crianças se divertindo. Sempre me emociona. Me lembro dos olhos dos passarinhos, quando eu ficava olhando para eles lá na fazenda. E eles sabiam que eu ficava olhando para eles também. O Bem te vi, sabia que eu ficava olhando para ele. E o sábio sabiá também sabia. Ah! Voar pelo ar... O melhor do ar não é de ninguém, é de todos, tudo que vemos lá em cima, não é de ninguém, não tem proprietário, é de quem quiser, sim, para quem quiser, é só construir uma máquina e ir viver lá... Na Estrela da Manhã! (Texto da peça, p.12).

Por meio dos trechos que se enquadram na dimensão humano pode-se perceber a abordagem da categoria teórica natureza da ciência e da tecnologia, uma vez que esses trechos colocam em evidência uma característica da ciência que, por vezes, é negligenciada. A de que a ciência é uma produção humana e, por isso, é resultante dos sonhos, dos desejos e dos anseios dos indivíduos.

No que concerne à presença da ciência e da tecnologia no texto da peça, ainda, foram encontrados trechos que remetem à categoria conhecimentos e conceitos da ciência e da tecnologia. Nesses, foram identificadas referências a teorias científicas, termos e conceitos tecnológicos e produtos da tecnologia.

Ele - (olhando para cima) A senhora está achando que vai chover? Se for chover eu preciso sair daqui, não posso ficar encharcado senão fico mais pesado e não vou conseguir voar (Texto da peça, p.2).

Ele - [...] foi considerado o menor balão já feito até então, com 100 metros de cubagem (Texto da peça, p.3, grifo nosso).

Ele - Agora quero ir até as estrelas mais distantes, quero ir até a Lua, quero andar no solo de Marte, quero voar por galáxias. , mas, por todo lugar por onde eu passar, se eu tiver viver sempre com os pés no chão, eu logo deixarei esse lugar, quero me libertar, para sempre, da Lei da Gravidade, quero dominá-la, voar por aí, sem barreiras, sem fronteiras (Texto da peça, p.12, grifo nosso). 
Ele - Não, na verdade ele já existia, as mulheres já usavam no pulso... Eu que fui o primeiro homem a usar um relógio de pulso... Durante os meus voos com os balões ficava incomodado por não ter possibilidade de cronometrar meu tempo. Não conseguia olhar o meu relógio que ficava na minha algibeira e dar conta de puxar as cordas de suspensão do balão e controlar o leme ao mesmo tempo. Olha só a dificuldade que eu tinha... Dê-me mais vinho e por favor, entregue-me a minha taça (ela pega a garrafa e a taça e ele coloca o relógio na cintura dela). Agora, diga-me que horas são? (Texto da peça, p.8, grifo nosso).

Ele - Essa é Aida D'Ácosta, uma jovem cubana, que foi atriz nos EUA. Com certeza ela devia ser uma grande atriz... Tamanho fora sua coragem e determinação. Imagine você... Ela foi a primeira mulher a realizar um voo, sozinha... E no meu balão, o número 9. Eu só a instruir em terra, no ar ela estava sozinha... A primeira mulher a voar e no meu Balão número 9. Um brinde à Aida! Um brinde às mulheres! (Texto da peça, p.9, grifo nosso).

Ele - Este sou eu, e essa é minha história... Não tenho mais nada para contar, até amanhã, amanhã falo do meu dirigível Demoseille, só amanhã... (Texto da peça, p. 14, grifo nosso).

Pesado, cubagem, lei da gravidade, relógio de pulso, balão e dirigível. Conquanto esses termos possam remeter ao universo da ciência e da tecnologia, eles são abordados no texto sem qualquer explicação ou definição que promova um conhecimento ou entendimento mais aprofundado. Assim, parece não haver intuito de que o espectador os entenda conceitualmente. Dessa maneira, o texto não enfatiza a categoria conhecimentos e conceitos básicos da ciência e da tecnologia. Contudo, considerando as proposições de Bybee (1995) a respeito da alfabetização científica, pode-se inferir que o texto da peça possibilitaria alcançar a alfabetização científica na dimensão funcional, a qual se centra na aquisição de um vocabulário científico que permite a percepção de que a ciência utiliza palavras apropriadas e adequadas.

\section{b.2) A encenação da peça}

A peça em si (encenada) foi disponibilizada para essa pesquisa em registro em VHS. A partir desse documento analisaremos o espetáculo, procurando explicitar se/como os outros sistemas cênicos, além do texto da peça, contribuem para a abordagem das proposições da alfabetização científica. 
A proposta de encenação se mantém fiel ao texto, havendo identificação e coerência entre o texto e a leitura da fábula pela encenação. Assim, a fábula relatada pelo texto encontra continuidade na encenação, com mesma organização, ambiguidades, lacunas e indefinições. A encenação não engessa o texto dentro de uma proposta de gênero específica, contudo, se percebe a modulação de tonalidades que aproximam o espetáculo da tragicomédia.

A encenação do espetáculo Larguem tudo! Vamos voar! é sustentada pela articulação de diferentes sistemas cênicos, como foi possível perceber por meio da filmagem da peça analisada. Iluminação, música de cena, sonoplastia, cenografia, objetos, atuação e texto dramático. Todos esses elementos atuam em conjunto. Por vezes percebe-se a continuidade do texto no corpo do ator ou na sua voz, da mesma maneira que se constata o cenário sendo alterado por objetos ou pela própria luz. Também se vê a música de cena se unindo a voz dos atores para enunciar diferentes emoções. Dessa maneira a relação que se percebe entre esses sistemas cênicos é a de complementaridade, conforme relataremos com maiores detalhes adiante.

No que se refere ao contexto cultural e estético a encenação segue tendências do teatro moderno (RYNGAERT, 1996; ROUBINE, 1998): o texto não tem um lugar de destaque; o espaço de atuação extrapola o palco tradicional; o cenário rompe com a proposta pictórica do naturalismo; o conjunto dos sistemas cênicos é quem produz a enunciação. Alguns aspectos fortes da encenação são a utilização dos objetos, em especial a proposição do objeto caixa preta que, como descreveremos, congrega funções utilitária e simbólica, está última, importante para a enunciação a que se pretende o espetáculo. Também merece destaque a organicidade com que os sistemas cênicos por vezes se articulam, interferindo uns nos outros. E a aproximação do espectador, por meio da expansão do espaço cênico no rompimento da barreira palco/plateia. Os aspectos fracos passam pela manutenção das imprecisões e indeterminações presentes no texto e que têm continuidade na cena. Essa filiação acaba por possibilitar interpretações diferenciadas a respeito da fábula. Também conta contra o espetáculo a manutenção dos monólogos entre os diálogos dos personagens, a partir de determinado momento do espetáculo, conforme se percebe pelo vídeo, a plateia torna-se dispersa quando a situação do monólogo se repete. 
O cenário do espetáculo é um dos elementos que o constrói e não tão somente o ilustra. O espaço em que o espetáculo acontece é o auditório da Estação Ciência. Este local segue a proposta arquitetônica do palco italiano. Vê-se um palco elevado em relação à plateia e do outro lado as cadeiras para os espectadores. Apesar de essa matriz arquitetônica delimitar o espaço de representação, a proposta de encenação do espetáculo rompe com esse ordenamento do espaço, conforme será descrito.

Ao longo do espetáculo percebe-se que o cenário assume principalmente duas funções dramáticas, a de construção e modificação e a de subjetivação. A primeira é identificada quando os atores constroem os lugares e os momentos da ação a partir do espaço gestual e dos dispositivos cênicos. Já a segunda, se manifesta no momento em que diferentes cores e luzes são utilizadas com a proposição de alterar a impressão da realidade, com a finalidade de criar novas atmosferas no palco e na relação dele com a plateia. Dessa maneira as cores, as mudanças e as evoluções do cenário são decorrentes dos elementos textuais, dos dispositivos cênicos e da iluminação. Importante relatar que o espaço da cena em preto (próprio da arquitetura do teatro) favorece a neutralidade necessária às modificações que acontecerão ao longo do espetáculo.

As funções de construção e modificação são percebidas logo no início e são recorrentes ao longo do espetáculo. A peça começa com hino nacional tocando na cena em blackout. Em determinado momento o hino para e ouve-se sons de marteladas. Após um tempo de marteladas toca um samba, sem letra. A luz acende e o que se vê são as paredes negras do próprio teatro, uma caixa grande e preta (com rodas) ao centro, um banco, um guarda-chuva (à esquerda) e uma mulher coberta com um pano preto, realizando uma movimentação aparentemente sem sentido, mas baseada no ritmo do samba. A luz marca o ambiente da cena como sendo a parte central e à direita do palco, onde estão a caixa preta e a mulher.

A peça tem início com a apresentação desse cenário mínimo, no que se refere aos elementos materiais. No entanto, oferece ao imaginário da plateia estímulos sugerindo que a trama se desenvolverá no Brasil, ou mesmo, incitando que se vai tratar de algo brasileiro, seja pelo próprio hino nacional, seja pela execução do samba. Esses elementos da cultura brasileira denunciam a presença da categoria natureza da ciência e da tecnologia, uma vez que esses signos são utilizados para fazer referência a Santos Dumont enquanto pessoa, um brasileiro, possibilitando inclusive uma identificação do 
espectador. O som de marteladas, por sua vez, desperta a impressão de que algo está sendo construído, o ambiente de uma oficina, ou de uma marcenaria. Aqui aparece uma primeira concepção atribuída a Santos Dumont no espetáculo, e que vai sendo caracterizada como própria do homem de ciência, a atividade de construir, de planejar, de experimentar. Novamente aqui se percebe a presença da categoria natureza da ciência e da tecnologia. Essa perspectiva reaparece e vai sendo fortalecida em outros momentos.

O cenário vai se modificando ao longo da peça pela interação com os outros sistemas cênicos. Por exemplo, um ambiente é criado pela abertura de uma janela na caixa preta. A janela se abre para fora, como uma porta, e na face voltada para a plateia vê-se um céu azul, com algumas nuvens.

A essa imagem é acrescentado o som de pássaros e uma música instrumental, em violão. A música abaixa e o ator se apresenta como sendo Santos Dumont, nascido na fazenda Cabangú, em Minas Gerais. Nesse momento o cenário é construído principalmente a partir de três elementos: a imagem de céu azul com nuvens, a música e o próprio texto falado. $\mathrm{O}$ conjunto desses estímulos suscita o ambiente de campo, em que a personagem da trama nasceu e viveu parte da infância. Com o foco de luz branca sobre o ator segue-se um texto biográfico, relatando a infância de Dumont no campo. Em determinado momento outro foco de luz acende sobre a mulher, sentada em uma cadeira e com a sombrinha ao seu lado, expandindo o cenário da ação. Nesse instante o ambiente fica indefinido. Não há indícios de onde os personagens estão.

Em determinado momento do espetáculo o cenário se expande para a plateia. Essa modificação acontece no instante em que a mulher decide não esperar mais pelo helicóptero e ir embora. O palco fica iluminado com luz branca e uma luz branca é acesa iluminando a plateia. Nessa configuração acontece uma brincadeira sobre os animais que voam e um diálogo a respeito do voo do 14 bis. A expansão repete-se na cena em que a mulher deixa o palco para comprar pão de queijo em uma barraquinha fora do teatro. Nesse mesmo trecho Dumont se posiciona na plateia, à frente do palco, e conta a estória de Ícaro.

O cenário sofre modificações também a partir do efeito sonoro de um helicóptero. Nos momentos em que esse som aparece a mulher retorna ao palco, a luz diminui e ela grita chamando por Antônio, seu amigo piloto. Esses elementos constroem 
a imagem de um helicóptero sobrevoando o teatro. Paralelamente a essa ação, Santos Dumont entra na caixa preta e manipula o aparato mecânico constituído pelos dois bonecos de fazendeiros empurrando uma máquina de tirar água de poço. Novamente tem-se a visão de Dumont analisando e experimentando processos da mecânica. Esse momento remete à categoria natureza da ciência e da tecnologia. Nele é veiculada a ideia de que os processos da ciência passam pela observação e pela experimentação, sendo que um homem de ciência realiza esses procedimentos.

Em certo instante o cenário é modificado para um campo, na situação de um piquenique (figura 4.3). A caixa preta é retirada do centro do palco e um lençol branco (retirado de dentro dela) é estendido no chão. Sobre ele são colocadas duas taças, uma garrafa de vinho, uma cesta de pães de queijo e um porta-retratos. A mulher abre a sombrinha e a posiciona atrás do lençol, à diagonal esquerda. Dumont desenrola a pintura de um homem e uma mulher no campo, em meio a flores e árvores, em estilo impressionista, e a fixa na caixa preta, como um quadro. Esses elementos reunidos remetem o imaginário da plateia a uma paisagem bucólica, de campo, onde acontece o piquenique. A luz também contribui para a mudança do ambiente. Acende-se um azul e um rosa, com um foco em lente branca, bem suave, delimitando o espaço do lençol e das personagens. Adiante, na mesma cena, e ainda sobre a atmosfera do piquenique, acende-se uma luz branca e se desenrola um diálogo sobre fatos da vida de Dumont, tais como a cratera da lua com seu nome e o avião, também com seu nome, que caiu na baia de Guanabara, tendo como tripulação professores e amigos do inventor. Nesse momento Dumont é apresentado como uma pessoa comum, no sentido de que possui uma vida comum, com amigos, e que encontra tempo para realizar um piquenique na companhia daqueles que tem apreço. Aqui o homem de ciência aparece de maneira diferenciada da concepção tradicionalmente apresentada pelo público escolar e pela população em geral, para os quais ele não possui pouca ou nenhuma vida social. Sendo assim, através da desmitificação da figura do homem de ciência, essa passagem remete à categoria natureza da ciência e da tecnologia.

A função dramática de subjetivação do cenário é perceptível em diversos momentos. Destaca-se o momento em que tem início o diálogo entre as personagens Ele e Ela. O cenário fica delimitado à cadeira, à esquerda, e à caixa preta, iluminados com luz branca frontal e azul de contra. O próprio texto da peça, explicitado no diálogo, 
reforça a indecisão sobre onde se está. Poderia ser o heliponto 1 da zona oeste de São Paulo, o vazio, o vácuo, o palco de um teatro, um hospício, a casa de Dumont etc. O cenário se mostra como uma continuidade emocional do personagem Santos Dumont, que nesse trecho relata a sensação de perda de tempo e de espaço sentida por ele no momento em que realizou sua primeira experiência com voo. Nesse instante o cenário, por exercer a função de representar a emoção de Dumont, contribui para a identificação do homem de ciência como sendo, antes de tudo, um homem, com emoções e desejos. Assim, esse sistema cênico contribui diretamente para que se contemple a categoria natureza da ciência e da tecnologia.

Essa relação do cenário com a emoção da personagem se percebe também no instante em que um banco é montado dentro da caixa preta de maneira que o ator fica sentado ao fundo, na quina superior esquerda, com os pés apoiados (figura 4.5). A mulher, então, empurra e puxa a caixa preta pelo palco ao mesmo tempo em que Dumont relata insegurança quanto ao futuro profissional indefinido, no que se referia a cursar a graduação em engenharia. Aqui o ambiente fica indefinido e o dispositivo cênico é utilizado para traduzir a inquietação, bem como sua vontade de estar movimento (“deslizar pelos ares", como é dito no texto).

Em dois momentos do espetáculo a função dramática do cenário é percebida mais fortemente. A primeira delas é uma cena que se repete por diversas vezes ao longo do espetáculo. Nela, Dumont vivência as sensações e as emoções de alçar voo. Porém, esse voo não é o voo propriamente dito, proporcionado por qualquer aparato, seja um balão, um helicóptero, um avião, ou outro, mas um voo do pensamento, da alma, do ser humano Santos Dumont. Nesses instantes acende-se uma luz azul e uma luz rosa e Dumont ensaia o andar de um flamingo antes de alçar voo. A essa imagem é acrescentada uma música erudita suave. Esses elementos transmitem a serenidade, a paz e o equilíbrio que o voo traz ao personagem (figura 4.6). 


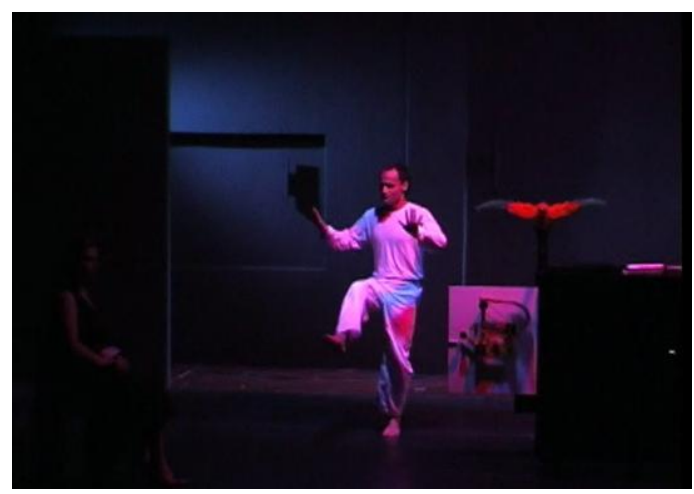

Figura 4.2: Voo do flamingo.

O outro momento é quando Dumont relata a morte de seu pai, de sua mãe e sua própria morte. Nesse momento a categoria natureza da ciência e da tecnologia é evocada pela abordagem da história pessoal de Dumont, bem como pelos sentimentos que ele vivenciou. Os sistemas utilizados para essa evocação foram o cenário e o objeto de cena. Inicialmente acende-se uma luz azul intensa que alcança todo o palco. À medida que o texto vai sendo dito, Dumont sai de cena e retorna com um papel vermelho, grande, que ele próprio agita no ar. Acende-se a luz rosa. Entra uma música percussiva, com ritmo acelerado de tambores. Dumont corre pela plateia agitando o papel vermelho (agora rasgado em dois pedaços), depois retorna ao palco e, ao som de o Guarani, tenta alçar voo, mas cai em cada uma das tentativas. Dumont fala o texto por sobre a música, que está alta. O cenário construído e o rasgar do objeto de cena são continuidade da angústia e do desespero da personagem (figura 4.7).

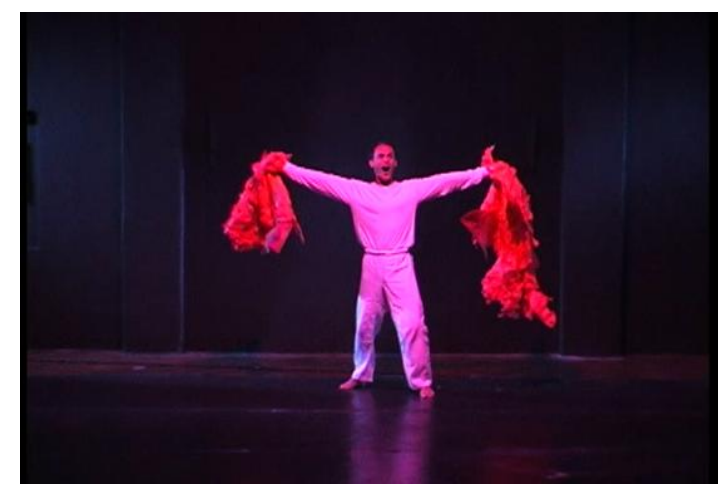

Figura 4.3: Morte de Santos Dumont.

$\mathrm{Na}$ encenação percebe-se que a iluminação tem a função de auxiliar na enunciação da cena. O sistema de iluminação é composto por uma geral branca, dois focos em branco ao centro, um foco âmbar na cadeira, luz azul lateral ao fundo e luz 
rosa no centro e ao fundo. A iluminação assume as funções de direcionar o olhar, tal qual acontece na cena inicial, em que um foco direciona o olhar da plateia para o ator dentro da janela; De colocar em evidência alguns elementos da cena, como acontece na ambientação da cidade de Paris, em que somente a torre Eiffel fica em destaque; De delimitar o espaço da representação, tal qual na cena do piquenique, isolando o ator. E de modificar a atmosfera da cena, atuando como uma extensão das sensações e emoções das personagens.

A luz branca frontal é utilizada na maioria dos diálogos, em especial nos que tem um caráter mais biográfico, enquanto nas cenas onde o foco são as emoções das personagens utiliza-se a luz azul e a rosa, conforme já foi relatado. Interessante perceber que a luz é utilizada também como um sinal para a plateia perceber que é chegado o momento de ela ser inserida na cena. Nas duas vezes que os atores rompem o limite do palco e atuam ao lado dos espectadores a plateia fica iluminada com uma luz branca. Assim, conclui-se que a luz assume a função técnica de iluminar o espaço em que acontece a atuação, mas também a de auxiliar na produção de sentido.

Os objetos do espetáculo também possuem funções diversas. Alguns desempenham função utilitária, como a cadeira, a sombrinha, a bolsa de mão, o lenço de rosto e o avião de papel. Esses objetos são utilizados à mesma maneira com que são manipulados no cotidiano, sem qualquer modificação de sua função ou significação. Outro grupo de objetos desempenha a função de intervenção no jogo de cena, alterando e construindo o cenário, é o que ocorre com o conjunto cesta de pães de queijo, taças e garrafa de vinho, porta retrato, pintura, lençol branco e dois guarda-sóis, que constroem o ambiente do piquenique. Dois objetos funcionam como extensão emocional do personagem, são eles o papel vermelho movimentado por Dumont no momento de angústia e dor, e as asas utilizadas para materializar o anseio e a necessidade de alçar voo. Aqui se percebe os objetos de cena evocando a categoria natureza da ciência e da tecnologia por traduzirem os sonhos, as emoções e os desejos de Dumont, identificando-o com um ser humano. Dois objetos são evocados por meio da sonoplastia, mas não aparecerem fisicamente em cena, são eles o martelo e o helicóptero, sendo que este último interfere diretamente na cena, modificando o estado emocional da personagem mulher. $\mathrm{O}$ som de martelo também contribui para que se contemple a categoria natureza da ciência e da tecnologia. Por diversas vezes esse som 
aparece no espetáculo, reforçando a ideia do homem de ciência como alguém que constrói coisas. Por fim, será ressaltado um objeto que é elemento central no espetáculo, e sobre o qual nos deteremos um pouco mais, a caixa preta.

A caixa preta é uma caixa grande, que abriga o personagem Ele e diversos objetos, ficando em cena durante todo o espetáculo. Ela é descoberta pela mulher logo no início e aberta, por dentro, pelo homem. Ele anuncia que é Santos Dumont e começa o relato acerca de suas visões de mundo, percepções, realizações, desejos, admirações, histórias de vida, sonhos etc. O homem passa bastante tempo atuando de dentro da caixa preta, mais da metade do espetáculo. É de dentro da caixa preta que aparecem os aparatos mecânicos que se tornam foco de atenção, de análise e de passa tempo do personagem Dumont.

Em determinado momento do espetáculo uma janela é aberta na lateral esquerda da caixa preta. Na parte interna da janela vê-se um aparato constituído por quatro polias fixadas em pedaços de madeira retangulares. Também se vê nele um sino, uma miçanga, um espanador, uma ventoinha e uma manivela (figura 4.11). Todo esse aparato é colocado em movimento quando a manivela é girada: a ventoinha roda, o espanador sobe e desce e a miçanga gira batendo no sino. Ele é manipulado por Dumont enquanto este passa seu tempo sozinho, aguardando a interação da mulher. Ainda no momento de espera pela interação ele joga um avião de papel de dentro da caixa preta, pela abertura superior. Esses elementos sugerem o envolvimento com a mecânica e com a construção de maquinarias. $\mathrm{O}$ fato de a personagem manipular o aparato e olha enquanto aguarda, de maneira descontraída e descompromissada, transmite a impressão de que ele passava o tempo pensando e criando coisas. 


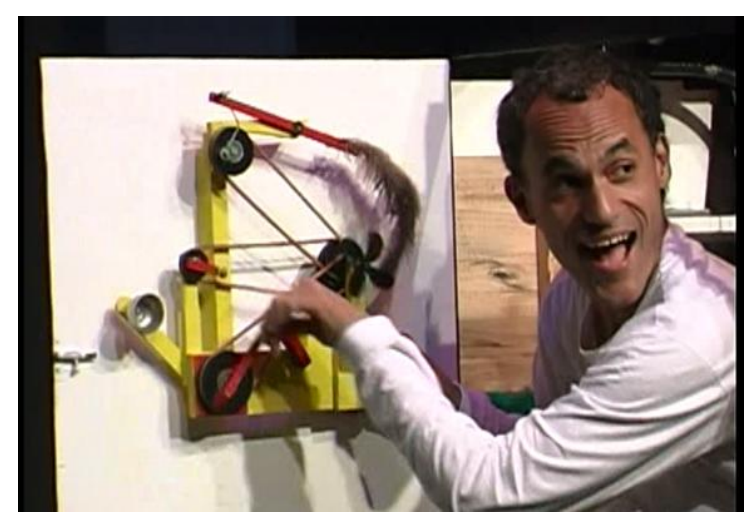

Figura 4.4: Aparatos.

Em outro momento do espetáculo uma ave mecânica, verde e amarela, é retirada da caixa e fixada na sua parte superior esquerda frontal. Essa ave é um aparato mecânico que bate as asas quando uma manivela é acionada (figura 4.12). A ave é colocada em cena no momento em que Dumont relata a criação do seu primeiro balão, o Brasil. Esse aparato pode a uma das falas iniciais do homem, em que ele diz imaginar existir um motor dentro dos pássaros que faz as asas baterem. Enquanto fala do balão, segue verificando se todas as peças da ave estão corretas e analisando se ela funcionará. Ao final do texto, quando relata o voo do Brasil, gira uma manivela e as asas da ave batem. Aqui se estabelece uma associação do voo do balão com o domínio da mecânica de voo do pássaro e, novamente, se atribui à imagem de Dumont a atividade de analisar e inventar aparatos mecânicos. Pode-se inferir, então, que a caixa preta remete à categoria natureza da ciência e da tecnologia, uma vez que esse objeto de cena agrupa aparatos e possibilita ações que permitem ilustrar o envolvimento de Dumont com a mecânica, bem como sua inventividade e curiosidade. Dessa forma, a caixa preta contribui para construção da ideia de homem de ciência. 


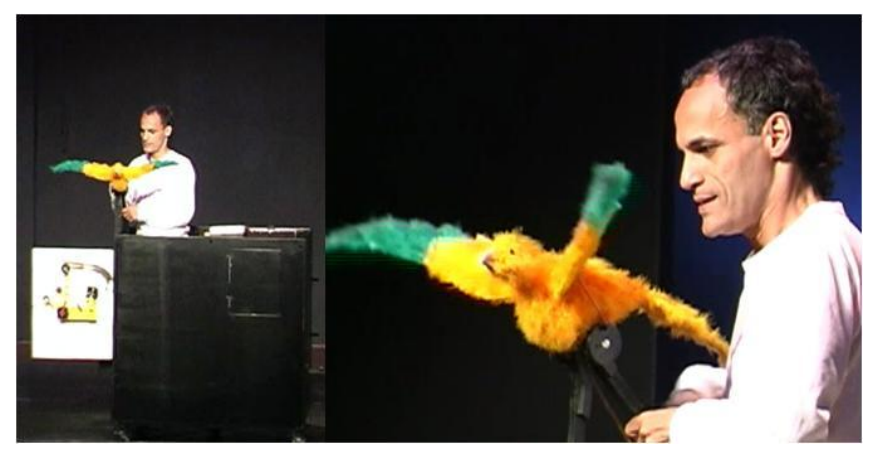

Figura 4.5: Pássaro.

A funcionalidade da caixa preta em evocar a categoria natureza da ciência e da tecnologia pode ser percebida também em outro momento, no qual são ressaltados a característica de inventor de Dumont, o aspecto empírico e a realização de experimentos. Dumont é visto dentro da caixa preta, agora com uma segunda janela aberta à direita. Nessa janela vê-se outro aparato mecânico: dois bonecos de fazendeiros posicionados para movimentar uma bomba manual de retirar água de poço (figura 4.13). Ouve-se barulho de marteladas e, depois, fumaça branca e gritos, dando a impressão de que algo explodiu. Dumont surge de dentro da caixa preta tossindo em meio a fumaça. Essa cena remete à visão clássica de homem de ciência, comumente veiculada na mídia, retratando o trabalho como experimentador que, vez ou outra, não atinge sucesso em seus planos. Ao longo do espetáculo, por diversas vezes, a imagem do trabalho manual na oficina é retomado através do recurso de sons de marteladas.

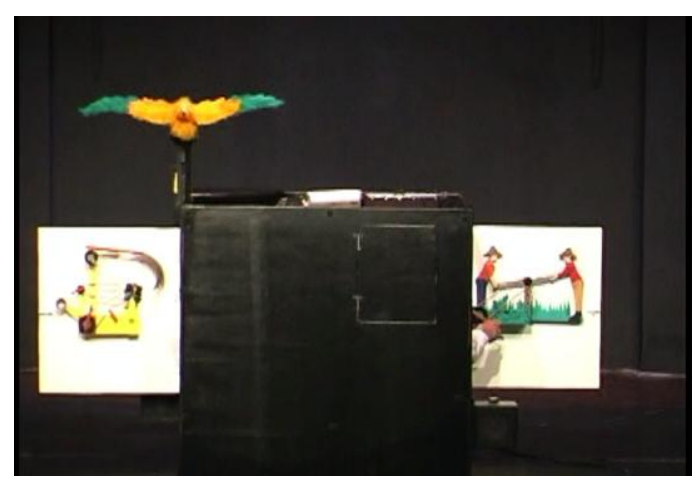

Figura 4.6: Caixa preta.

A funcionalidade real da caixa preta de ser uma consulta a todas as informações sobre o voo de uma determinada aeronave é transposta para o acesso a diversas informações sobre Santos Dumont. Assim, a caixa preta assume a função metafórica de 
propor a "abertura" da pessoa Santos Dumont para que o espectador possa conhecê-lo. O objeto caixa preta é uma menção direta ao universo da ciência e da tecnologia, fato que se repete novamente quando o objeto relógio é colocado em cena e se discorre sobre sua invenção. Entretanto, a caixa preta é apresentada em cena sem ser nomeada de caixa preta, ficando a cargo do espectador realizar a associação entre o objeto cênico e o conceito e o produto tecnológico.

Por fim, é importante ressaltar que, apesar de manter o significado da caixa preta, a apropriação desse produto tecnológico pela encenação resultou em algumas mudanças: a modificação no tamanho, uma vez que a caixa preta que vemos em cena é muito maior do que a correspondente na realidade; e a mudança na própria cor. Ao contrário do próprio nome a caixa preta não é preta, mas sim de cores chamativas, em geral, tons de alaranjado ou vermelho.

Os figurinos e a maquiagem não apresentam qualquer indício que permita caracterizar especificamente as personagens. Por exemplo, não se percebe semelhanças entre a personagem Santos Dumont e o próprio, que nos é retratado em livros ou registros biográficos. Ao invés de terno, gravata, sapatos e chapéu remetendo ao início do século XX, o que se vê é um ator vestido com uma calça e uma camisa de mangas longas, ambas brancas, e descalço. O tecido não pesa no corpo, o figurino é ligeiramente largo, ficando solto de maneira a adaptar-se às performances corporais do ator. A camisa e a calça com elástico na cintura cobrem o corpo sem impedir a mobilidade.

Já a atriz, está com um vestido preto de alças, que avança sobre o joelho chegando às canelas, e decote em v. Os ombros e o torso ficam expostos. Porta sapatos de salto alto e bolsa de mão, ambos vermelhos. Brincos longos, assemelhando-se a brilhantes. Cabelos presos por presilhas e um coque. No rosto dos atores é perceptível uma maquiagem neutra, sem marcação de contornos ou destaques, apenas o mínimo necessário à apresentação frente aos refletores. Apesar de o figurino da mulher propor uma imagem menos neutra do que a de Dumont, não fica claro quem ela seja (figura 4.10). O vestido preto que nos é apresentado poderia ser usado por qualquer personalidade feminina, uma vez que ele é a vestimenta de um momento especial, um voo de helicóptero, nunca antes experimentado, o que incita a ideia de uma preparação especial. 
O figurino e a maquiagem incutem certa neutralidade aos personagens. Assim, não fornecem indícios precisos a respeito de idade, profissão ou classe social das personagens, bem como sobre a época e o local em que a fábula acontece. Essa proposição de não caracterização possibilita a não identificação de Dumont com o mito do homem de ciência, mas com pessoas comuns, do cotidiano, com as quais se encontra no dia a dia. Novamente há o reforço de que a ciência e a tecnologia são realizadas por pessoas comuns, seres humanos, agora por meio do sistema cênico figurino, contemplando a categoria natureza da ciência e da tecnologia.

Conquanto se perceba a neutralidade dos figurinos é possível identificar uma relação de oposição entre os figurinos dos dois personagens. Enquanto o figurino de Dumont é branco, o da atriz é preto. Essa oposição pode representar a diferença entre os estados dos personagens: aquele que conseguiu alçar o voo (não só o físico, mas o de pensamento) porta a cor atribuída à tranquilidade, à paz e ao equilíbrio, o branco. Enquanto aquela que está presa ao solo, emocionalmente instável, desejosa do voo, carrega consigo o peso da cor preta.

Os corpos que nos são apresentados por ambos os atores quando encarnados pelos personagens também não são caracterizados, são corpos sem acentuações marcadas. Corpos cotidianos em gestos e expressões faciais, diria, não fosse pelo aparecimento momentâneo de movimentos ora prolongados ora contidos, ora ligeiros ora cadenciados, e de expressões bastante acentuadas. Por vezes o corpo e a voz são tidos como uma continuidade do texto. Na qual um movimento prolongado de braços coincide com uma palavra prolongada, ou em que a sequência de textos curtos coincide com gestos curtos e precisos.

A interação entre o texto, o corpo e a voz é frequente. Como se pode verificar, por exemplo, na cena em que Dumont esta sentado na caixa preta e a mulher o movimenta pelo palco. No instante em que a caixa preta é empurrada de um lado para o outro a voz d'Ele faz uma escala ascendente, para o agudo (“ir prá lá...”), e depois uma escala descendente, para o grave (“ir prá cá...”). Esse jogo se repete algumas vezes, acompanhado de indicação da direção com o braço estendido e a mão apontando uma meta. Nesse momento os corpos são vistos relaxados e as feições são de alegria, significando o conjunto como uma brincadeira. 
A postura corporal dos atores adquire contornos diferentes em cenas específicas, tais como as cenas de voo do flamingo, da morte dos pais ou as cenas sobre as tentativas de voo e sobre a mudança de Dumont para o Guarujá. Nessas cenas o corpo torna-se mais plástico, com gestos mais marcados em oposições, expansões, prolongamentos, ritmos e intensidades. Como ilustração, analisemos a recorrente cena do voo do flamingo: Nesses instantes o ritmo corporal é modificado, tendo sua cadência e intensidade diminuídas. Em comunicação com a atmosfera lírica criada pela iluminação e pela música de cena o corpo assume uma postura também lírica e metafórica, representando o próprio flamingo. Os movimentos que se veem, no entanto, procuram mostrar a cadência, a constância, a firmeza e a suavidade do movimento do flamingo e não uma mímica do animal. Essa postura corporal é marcada por movimentos de expansão e contração do tronco e alterações no ritmo tanto dos braços, que são movimentados para frente e para trás, quanto das pernas, no andar bem marcado. Cada movimento inicia-se com rapidez e termina em lentidão. Ainda, a inspiração torna-se profunda e cada expiração é marcada por um ronronar. Sorrisos e expressões de satisfação completam o quadro, significando o prazer e a plenitude sentida no realizar o voo. Nessa cena do voo do flamingo, que se repete por diversas vezes, é retratada toda subjetividade e emocionalidade de Dumont no seu alçar voo, no voo do seu pensamento. É perceptível a mobilização da linguagem corporal para que o estado emocional de Dumont seja transfigurado, retratando o ser humano em êxtase. Dessa forma, inferimos que o trabalho de corpo dos atores também proporcionou a abordagem da categoria natureza da ciência e da tecnologia. Importante ressaltar que cada um dos atores tem um momento de performance de dança durante o espetáculo. Primeiro a mulher, que já no início dança o samba. O dançar não é exatamente a execução dos passos do estilo musical samba, mas uma movimentação corporal inspirada no ritmo do samba. A atriz está com o rosto e parte do corpo cobertos por um pano preto e o resultado que se tem, então, é plástico, com o corpo materializando os sons do samba. Depois Ele, que em determinado momento do texto anuncia o desejo de dançar e o faz utilizando um misto de gestos da capoeira e rolamentos do contato e improvisação, dentre outros.

As falas dos atores são marcadas pela utilização de diversos tipos de entonações: tensas e sombrias (cenas de desespero), abertas e alegres (ida para Paris) etc. Os atores 
brincam em diferentes timbres, intensidades e fluxos verbais, de maneira a introduzir no texto escrito uma significação particular. Veem-se quebras causadas pela mudança na intensidade da voz (que de alta torna-se baixa), no timbre (que de agudo torna-se grave) ou pela utilização de uma pausa que, frequentemente, aparece como um indicativo de reflexão sobre o que está sendo dito. Por vezes são utilizados efeitos na voz para enunciar o texto e associá-lo a um movimento. A dicção é marcada pela articulação das palavras sem promover nenhum destaque que caracterizasse as personagens como pertencentes a algum lugar específico. O canto aparece em dois momentos, sendo executado sempre por Dumont e realizado à capela. Nesse momento há uma mudança, o corpo que antes parecia firme se deixa modificar, tornando-se maleável de acordo com as variações da sonoridade evocada.

A análise da cena inicial nos dá um indício das nuances da voz no espetáculo: Ele está dentro da caixa preta. Uma janela aberta. A fala é serena relata o nascimento e a infância de Dumont. A voz é não possui modulações. O fluxo verbal é constante, sendo interrompido por pausas breves, impingindo ao texto a inflexão de reflexão sobre o que está sendo dito. A face também guarda serenidade. O olhar, que no início da cena estava transitando pela plateia em comunicação direta com o espectador, encontra um ponto fixo e fica vago, no horizonte. Nesse momento a fala diminui de ritmo e as palavras são ditas com prolongamento. O resultado que se tem é de que se está falando de algo distante, longínquo, na memória. Todo o texto é dito com certa lentidão e marcado por pausas. Há uma quebra no ritmo do texto e das expressões faciais no relato sobre a ideia de que havia um motor dentro dos pássaros. A fala fica com ritmo mais rápido e intenso, as expressões faciais são intensificadas e a modulação da voz muda, tornando um pouco mais aguda. Vê-se risos e uma fala mais aberta. A intensidade da voz fica mais forte. Pouco depois retorna-se a uma cadência mais calma e constante, não tão suave quanto no início. A expressão do rosto vai voltando para a serenidade, quase neutralidade, do princípio. Ao falar com Ela o ritmo da fala e as expressões do rosto assumem uma postura cotidiana. Voz um pouco mais acelerada e expressões faciais materializando a informação dita. Quando retorna ao relato da infância vê-se novamente a postura de serenidade/neutralidade e fala pausada. Quebra no ritmo quando inicia-se o diálogo entre Ele e Ela. A fala torna-se mais ligeira, acompanhando a proposição implícita dos textos curtos que cada um dos atores pronuncia. As palavras são 
pronunciadas sem prolongamentos, em staccato. Contudo, se utiliza de pausas e mudanças de intensidade da voz para realizar acentuações.

Na proposta de atuação o espaço cênico é ocupado em sua totalidade. Ao longo do espetáculo os atores se movimentam explorando o palco em todos os seus locais. Importante ressaltar que em alguns momentos o espaço da plateia também se torna espaço cênico. Nesses momentos os atores dialogam diretamente com os espectadores. Conquanto o estilo de atuação relatado seja compartilhado pelos dois atores que compõem o espetáculo, percebe-se uma maior exploração das habilidades artísticas do ator em relação à atriz. Dele são exigidas performances de dança e de canto. E o jogo de cena passa mais tempo nas mãos dele do que nas mãos dela.

A música de cena utilizada na peça é do tipo mecânica e constitui-se como um dos elementos que produz a enunciação da cena. Ao longo do espetáculo, ela criar ambiência, como no caso do hino nacional. Algumas vezes ilustra e cria atmosfera correspondente à situação dramática, tal qual acontece no momento em que Dumont anuncia a ida para Paris e imediatamente ouve-se uma música francesa. Ou quando a mesma personagem fala de sua família, nomeando seus parentes, e ouve-se a música Trenzinho Caipira, referência direta a Minas Gerais. Importante rememorar que ela contribui para a construção do cenário, como já foi relatado. E, por fim, reforça o estado emocional da personagem, pintando um estado da alma, como nas cenas do voo do flamingo, em que se utiliza uma música erudita suave, e da morte dos pais de Dumont, em que se utiliza uma música percussiva forte, com tambores. As músicas utilizadas no espetáculo atuam no sentido de reforçar a ideia de Dumont enquanto pessoa comum, seja no momento em que assumem a função de expansão das emoções vivenciadas por ele, seja quando procuram demarcar um regionalismo brasileiro ou mineiro do inventor. Nesse sentido, a música de cena evoca a categoria natureza da ciência e da tecnologia.

Em duas situações o ator entoa músicas cantadas à capela. Uma delas é a melodia cantarolada em todos os momentos em que ele se distrai manuseando e interagindo com a caixa preta. E, a segunda, é cantada no momento em que a mulher chora por achar que foi esquecida pelo seu amigo, o piloto de helicóptero. Essa música interfere diretamente na fábula, pois através dela o personagem convence a mulher a se envolver no diálogo e conhecer sua história.

Para além da música de cena, o espetáculo se utiliza também da sonoplastia. 
A sonoplastia é a reconstituição artificial de ruídos, sejam eles naturais ou não. A sonoplastia deve ser distinta, ainda que isso nem sempre seja tarefa fácil, da palavra (em sua materialidade vocal), da música, dos resmungos e, sobretudo, do ruído gerado pela cena (PAVIS, 2008, p. 367).

Nesse sentido, a sonoplastia assume a função dramatúrgica de imitar um som, de efeito de real. Esse recurso é utilizado no espetáculo tanto para criar cenários a partir da evocação de sons e ruídos característicos, tal como o som de passarinhos para construção da imagem de fazenda; as marteladas, que sugerem a existência de trabalho manual em uma oficina; ou o som de helicóptero, que antecede as performances da mulher para ser encontrada.

A sonoplastia é um dos sistemas utilizados na encenação para a construção da ideia de homem ciência. A martelada é o signo que assume essa função. A primeira vez que ela aparece é logo no início do espetáculo e incita a imagem de que algo está sendo construído, depois, é ouvida mais duas vezes, em uma delas precede uma explosão e, na outra, sucede a fala de que Santos Dumont irá trabalhar. Esse conjunto de cenas nos permite inferir que, segundo a concepção do espetáculo, o trabalho manual, de construção, é uma característica do homem de ciência, e, por conseguinte, do fazer ciência. Essa concepção parece guardar relação com a perspectiva empirista de ciência. Atualmente, entende-se que o trabalho empírico pode ser parte do processo científico, entretanto, ele não é o critério único para se identificar algo como sendo ciência. Contudo, consideramos que a problematização dessa concepção atende a finalidade de se abordar a categoria teórica natureza da ciência e da tecnologia.

O ritmo do espetáculo, entendido como mudança de acentuação, de percepção de momentos acentuados e não acentuados (PAVIS, 2008), é mantido por meio dos sistemas cênicos. Assim, ora o espetáculo sofre acentuação por meio da mudança de luz, que destaca uma ação ou intensifica o ambiente. Ora pela música de cena, que reforça diferentes estados emocionais. Ora pelos diálogos, que brincam tanto com a entonação com que o texto é apresentado quanto com a velocidade. Importante ressaltar que a ocupação do espaço cênico também influencia no ritmo desse espetáculo, uma vez que a ocupação do espaço do espectador (proximidade) tende a acentuar a comunicação. Dessa maneira, o ritmo do espetáculo se modificar ao longo da peça, entretanto, de maneira geral, o espetáculo possui uma cadência ligeira. 
Conquanto o espetáculo trate de uma personalidade do universo da ciência e da tecnologia, não há pré-requisitos para apreciar o espetáculo, nem mesmo ser conhecedor em ciência ou tecnologia. Entretanto, se o espectador for conhecedor da biografia de Dumont, poderá ter facilitado o entendimento de uma passagem em especial, a brincadeira "homem voa". Durante o espetáculo, o personagem Ele interpela a mulher com questionamentos sobre o que voa ("Madame, macaco voa?"). Esse jogo era realizado por Dumont e seus amigos, na infância. Porém esse fato não é explicitado na encenação $^{15}$.

$\mathrm{Na}$ filmagem analisada do espetáculo o público reagiu de maneira positiva à encenação. Foi perceptível o envolvimento dos espectadores em grande parte do espetáculo, conquanto se perceba alguns deles conversando na plateia. De forma geral, inclusive nas cenas em que os atores vão à plateia e conversam diretamente com os espectadores, a recepção foi positiva. Durante a gravação se ouve comentários de espectadores analisando o espetáculo, procurando entender a encenação. Isso pode ser um indício de um esforço do espectador em produzir o sentido de algumas atuações específicas. Por exemplo, na cena do voo do flamingo, a subjetividade da ação não deixa claro se o personagem está mesmo voando ou não, conquanto os gestos levem a crer que sim. A encenação se utiliza dos diversos sistemas cênicos para manipular a atenção do espectador e manter seu envolvimento com o espetáculo. Verifica-se a utilização de objetos que despertam a curiosidade (aparatos mecânicos), uma atuação tendendo ao realismo (favorecimento de empatia), a inclusão da plateia como espaço cênico, dentre outros.

Para além dos feitos, inventos e sonhos de Santos Dumont, o que também permanece do espetáculo é a imagem de um homem que teve um objetivo e que, em um esforço pessoal, mobilizou os recursos necessários à sua realização. Bem como o tema voo do pensamento, latente em toda a encenação. Mais do que um relato dos voos materialmente e fisicamente realizados por Dumont, o espetáculo retrata o voo do pensamento, libertando-se das determinações profissionais, dos conhecimentos existentes, das situações dadas e dos medos, dentre outros. Nesse sentido o espetáculo aborda e estimula o desenvolvimento da liberdade intelectual por parte do espectador,

${ }^{15}$ Essa passagem pode se entendida pela leitura da obra autobiográfica: DUMONT, A. S. Os meus balões. Fundação Rondon, 1986. 
em acordo com as proposições de Pella et all (1966), com respeito à alfabetização científica, contemplando a categoria natureza da ciência e da tecnologia.

\section{c) 0 Voo no contexto da Estação Ciência}

O espetáculo Larguem Tudo! Vamos voar! foi realizado de maneira articulada com a exposição do museu. A interação se realiza tanto no que se refere ao diálogo com a temática quanto no que diz respeito ao estabelecimento de diretrizes para o espetáculo:

Um grupo de teatro, claro que poderia simplesmente pensar num tema, abordar esse tema e realizar o seu espetáculo. Independente! Porém, dentro da Estação Ciência, ou de um Museu de Ciência, faz bem, assim, até para tornar essa complexidade mais compreensível, abordar o tema, ou colocar a situação cênica cúmplice do fazer de todo o Centro. E aí a Companhia Fábula da Fíbula do Núcleo de Artes Cênicas, tem produzido peças dessa maneira mesmo. A gente sempre discutiu com a equipe, com o setor educativo. Como a peça iria ser formulada, que público que iria atender... Porque imagina, a Estação Ciência tem um público caracterizado mesmo entre oito e dezoito anos de idade. Oito, dezesseis, que é o equivalente aí ao Ensino Fundamental e Médio. Aí a gente faz uma peça para adultos? Quer dizer, que conexão é essa? Ou, a gente sabe que é um público que vem com interesse de obter informações elementares ainda, introdutórias desse universo científico. Aí vai lá e a gente só fala... O texto... A gente formula um texto onde só iniciados, só pesquisadores poderiam compreender. Quer dizer, desconexão total. Ou mesmo, vem um público aqui que... É... Um poder aquisitivo maior, mas antes, nem tanto. Aí a gente usava só equipamentos de última geração, onde não dava possibilidade desse público poder realizar também experimentações teatrais em sua escola, em sua comunidade. Enfim, há sempre, e sempre houve, uma preocupação onde o que está sendo trabalhado dentro da Estação Ciência participe sim do processo de trabalho do teatro (Entrevista Coordenador).

Esse procedimento de diálogo com as outras ações museais é coerente com os dados encontrados em nosso estudo exploratório, os quais indicaram que das 14 instituições participantes somente uma afirmou que a temática do espetáculo não se relaciona com a temática em trabalho no museu. O teatro é tido como cúmplice das outras ações, contribuindo para o entendimento da complexidade do museu. Conquanto não tenha ficado clara a ideia de complexidade do museu, que poderia se referir aos sujeitos, aos objetos, às relações entre as atividades, dentre outros, a noção de que o teatro atua em parceria parece ser concepção bastante consolidada. É importante, então, caracterizar melhor em quais aspectos essa parceria acontece. 
$\mathrm{Eu}$ acho que o teatro consegue abordar qualquer assunto, qualquer tema... Consegue sim. Agora, é difícil os outros não conseguirem também, porque aí é um processo, para mim, muito claro, de como essa informação está sendo transmitida. Quais são os recursos? Quais são as ferramentas? Há o entendimento exato do público a ser atingido? Há um entendimento exato do que é esse espaço? O que ele oferece? Há um entendimento do processo educacional mesmo, educativo, que está sendo formulado ali para interagir com este público que está vindo aqui? Então você tendo isso claro, eu acho que um diorama, uma exposição, um painel... Ele pode dar conta. Ele pode dar conta, porém, levando em conta esses aspectos: pra quem eu estou me dirigindo? Qual o nível de entendimento dessa população? Quais são as possibilidades de desdobramento, na vida dessa pessoa mesmo? $\mathrm{O}$ que eu posso sugerir como um espaço a ser aberto e ele andar nesse espaço? (Entrevista Coordenador).

Em um primeiro momento o teatro é colocado em igualdade com as outras estratégias de comunicação do museu. Não existiria um aspecto particular que somente ele tivesse a possibilidade de abordar. Ao que parece, na perspectiva do entrevistado, o que se deveria considerar não seria propriamente a estratégia comunicacional, mas o como essa estratégia é pensada. Aqui, fica claro a necessidade do estudo do público a quem a estratégia se destina e do como fazer para que a informação apreendida esteja o mais próximo possível da emitida, em todas as suas nuances. A perspectiva da igualdade permanece:

Então aí eu penso muito na escola, um professor vir aqui com os seus alunos, a gente sugerir determinada situação onde essa sugestão possa ser desdobrada em sala de aula. Então, por exemplo, o diorama, uma maquete mesmo... Se eu pego uma maquete e quero falar sobre arquitetura, os prédios mais incríveis de São Paulo, e simplesmente pego essas maquetes prontas e coloco ali, e coloco o nome da pessoa que fez, tudo bem, a pessoa vai registrar, falar "Ah, prédio bonito, uma maquete bonita, o nome". Mas se eu coloco uma situação onde, esses alunos vão pegar determinado esboço, onde vão ler esse esboço e a partir dele criar uma situação de interação com outros e nessa interação construir esse prédio, que vai ser a maquete mesmo, vão construir. A relação é outra, não é uma relação só de observador, de olhar, mas de alguém que imbuiu desse espírito mesmo de curiosidade, de construção, de realização. Verificou algo, pesquisou junto com outro, discutiu, e ao discutir realizaram a obra. E essa obra, no final, é aquela maquete. Aí eu percebo que, dessa forma, esse "como fazer", pode também resultar em algo como o teatro, se tornar imprescindível para certas questões (Entrevista Coordenador). 
Nesse momento o entrevistado procura demonstrar como as características que até então eram atribuídas à abordagem teatral, tais como interatividade, o estímulo à curiosidade e à liberdade intelectual, e que contribuem para alfabetização científica no que se refere à categoria natureza da ciência e da tecnologia, poderiam ser trabalhadas por meio de outras estratégias. Por fim, apresenta outra característica do teatro no museu, sua adaptabilidade, de forma a contemplar a diversidade de assuntos em circulação no museu.

[...] Porque nós tivemos exposições aqui na Estação Ciência onde havia uma preocupação muito grande em lidar com todos esses aspectos educacionais, de criação, do público a ser atingido, o número de pessoas, espaço para transitar, relação com a exposição, com a outra que está lá embaixo. Como a gente poderia linkar uma exposição do Zumbi com o painel do Big Bang? Então, nessa preocupação toda, a gente criou uma exposição onde havia essas conexões. Como no teatro também, ao desenvolver determinada peça sobre conexões cósmicas a gente... O primeiro passo foi olhar para o painel do Augusto Damineli, do Big Bang, e depois toda a área que falava sobre a cosmologia, mas, além disso, chegamos até Zumbi dos Palmares e outras né, a Química, e tudo. Enfim, ao realizar um espetáculo falando sobre planetas, Astronomia, a gente chegou à Química que estava aqui na Estação Ciência. Então esta questão do como é sempre muito importante. [...] Tem a palavrinha mágica que transforma tudo isso que é "como?" Como fazer com que isso chegue até a outra pessoa? (Entrevista Coordenador)

Novamente, a característica de adaptabilidade aparece como sendo possível de estar em quaisquer das estratégias de comunicação do museu, desde que se considere, sempre, o como. Existiria, então, alguma contribuição peculiar do teatro, diferente das disponibilizadas pelas outras estratégias de comunicação utilizadas no museu?

Não, não, existe sim. É que nem todas as exposições, como acabei de falar agora, estão dando conta! Então, nem tudo o que a gente produz acerta, e mesmo aquelas que a gente acerta a gente sempre vê... "Opa, tem que melhorar ali". Então, tem essa questão, nem tudo que está exposto, nem tudo que foi feito, resultou em algo realmente com a compreensão para todo o público que veio aqui. Ok, então, já teria esse espaço para isso. Outra coisa, e isso não quer dizer que o teatro também chega e resolva. Não. É... Precisa saber como, também, a ação cênica é colocada, que é algo que nós já conversamos um pouco. [...] mas o teatro é também uma ferramenta, e é aí que eu acho que ele tem espaço. Não querer substituir nada, nem dizer que é a solução, mas simplesmente por ser mais uma ferramenta. Claro que é uma ferramenta que eu considero impactante, por essa comunicação ao vivo, tá ali, "téti à téti", ouvindo aqui e agora, percebendo com a 
reação, percebendo o estado emocional do artista, sentindo a respiração dele, se ele está sendo sincero no que ele tá dizendo ou não, se ele acredita no que está dizendo ou não (Entrevista Coordenador).

A contribuição própria do teatro, na concepção do entrevistado, parece estar relacionada a dois aspectos. Um deles seria sua facilidade de adaptação no apoio às outras estratégias. O teatro pode atuar de maneira complementar a exposição, realizando ajustes em termos de informações científicas que não tenham ficado claras, abordar conteúdos que não couberam (em termos de espaço), entre outros. Dessa forma, ele auxiliaria ao público na compreensão das estratégias já existentes no museu. Com essa finalidade, o teatro é reconhecido como uma ferramenta para a melhoria das estratégias de comunicação presentes no museu.

O outro, atribuído como sendo próprio do teatro, é o contato humano, no que se refere à interação com o artista, com sua presença física e emocional. Essa característica promoveria um tipo de impacto diferenciado das outras estratégias. Dessas duas contribuições, a segunda (contato humano) tem sido relatada pela literatura (GARDAIR E SCHALL, 2009; OLIVEIRA \& ZANETIC, 2004; ANDREIS, 2009) como sendo própria do teatro com temática científica para a divulgação da ciência ou para a educação em ciências. Já a primeira contribuição está sendo identificada e registrada pela primeira vez nessa pesquisa, e pode ser decorrente do fato dessa prática de teatro estar inserida no museu de ciências.

Na perspectiva do coordenador o teatro no contexto dos museus de ciências é uma estratégia associada, ao invés de complementar. Entendendo-se que a relação de associação significa que todas as estratégias têm possibilidades iguais de abordar os aspectos da ciência, desde que o como seja bem pensado. A associação traria a vantagem de disponibilizar uma diversidade de caminhos pelos quais a informação científica seria comunicada. Já a complementaridade estaria relacionada à situação em que cada estratégia tivesse possibilidade de abordar apenas determinados aspectos da ciência. Assim, seria necessário que várias estratégias complementares fossem utilizadas para que a ciência pudesse ser entendida em seu todo.

Essa questão cênica! Então, o espaço também, ele é um possível selecionador de ferramentas. Se eu levo, por exemplo, uma exposição, como nós tínhamos aqui sobre tecnologia, para um espaço onde, não tem conexão de rede, vai ser o quê? "Nossa trouxeram uma exposição incrível, ah, tá lá, tão incrível que não dá pra a gente usar!" Que 
divulgação cientifica é essa? Mas, então, quer dizer, uma exposição incrível, que pode ser transformadora mesmo, mas que em determinado espaço não funciona, porque não tem os recursos necessários para atender. Aí, um palhaço pode ir lá e falar da tecnologia brincando com concentrações de esquetes, de brincadeiras assim, com toda a questão do lúdico (Entrevista Coordenador).

Conquanto todas as estratégias possam ser adaptadas, ou planejadas, para a abordagem de quaisquer aspectos da alfabetização científica, o teatro parece possuir o diferencial de se adaptar com certa facilidade aos espaços disponíveis para a comunicação da ciência.

Sim, sim. E aí, também, a gente fugindo um pouco daquele estilo de "teatrão", no sentido mais clássico, com todas as iluminações. Aí tem que rebolar. Eu queria deixar muito claro, assim, essa questão do teatro. O professor Eduardo Mascarenhas, uma vez também fez essa pergunta para a gente numa mesa sobre Ciência e Arte. Ele falou "Ah, então vocês querem substituir a sala de aula pelo teatro?" Claro que ele falou isso só para provocar. É uma pessoa muito inteligente, não achava que era isso mesmo. Mas, provocando a gente, falou isso. Aí eu "claro que não". Em nenhum momento o teatro deve substituir a sala de aula. A sala de aula é o ponto de concentração não é? De todos os estudos, de toda a formação do aluno. Esses elementos todos que acontecem, visita à exposição, a museu, ao cinema, ao teatro, são atividades paralelas, complementares à sala de aula, complementares! [...]Porque o professor ao situar determinado tema, assunto curricular, para expandir essa interpretação, ele pode procurar o teatro, pode procurar o cinema, pode procurar o museu, e nesses lugares encontrar possibilidades de levar outras interpretações para o assunto que está abordado dentro da sala de aula, ampliar mais esse conteúdo. Aí sim, aí se torna complementar. E enriquecedora, porque você só não tem a possibilidade de complementar, em termos de informação mesmo "olha, completei", mas também, de possibilitar... Conhecer novas interpretações para aquilo, novas formas de abordar aquilo (Entrevista Coordenador).

O teatro, assim como as outras estratégias do museu, pode assumir a função de ação complementar à sala de aula, no sentido de ampliar e diversificar as discussões que são realizadas no espaço de educação formal. Essa perspectiva é coerente com os autores (CAZELLI E FRANCO, 2001; COUTINHO-SILVA ET AL, 2005; CONSTANTIN, 2001) que discutem sobre a relação entre os espaços formais e não formais visando a educação em ciências.

A gente situa muito na educação não-formal... E até voltando um pouquinho, nós tínhamos falado de uma ação complementar à sala de 
aula... Onde, um assunto abordado dentro de uma sala de aula pode ser investigado, ampliado, ter, outras visões a partir do acesso à uma peça de teatro. Como também, ao acessar uma peça de teatro, ele pode ter um desdobramento em sala de aula, ou, na comunidade. É como a Companhia Fábula da Fíbula em vários momentos fez acontecer. Ao se apresentar, aí surge a necessidade de levar o assunto para sala de aula, de discutir, de reproduzir, de recriar. E com isso ganhar novas dimensões. Então o teatro não... Num espaço como esse, ele tem sim essa importância, de ser um ato, uma ferramenta importante mesmo de disseminação do conhecimento, mas principalmente, uma ferramenta onde as pessoas tem a possibilidade de usá-la (Entrevista Coordenador).

Importante ressaltar que as referências para a criação dos espetáculos, no caso do Fábula da Fíbula, tem vindo de locais diversos:

No espetáculo “A estrela da Manhã" a gente foi buscar sim. Tinha o professor Hamburger, que é físico experimental nuclear, Amélia, que era filósofa da Ciência. Nós tivemos colaboradores da área de educação, da faculdade da educação, a professora Miriam, e várias outras pessoas nos ajudaram também. E, além disso, essas saídas também às bibliotecas. Então, encontro com os livros, o encontro com vídeos, você investigar em determinadas TV's, alguns canais, programas que se relacionavam com o assunto, o "Discovery" foi muito usado. Palestras, a gente trazia especialista de determinadas áreas, para fazer palestras para a gente, para o grupo em estudo. Como a gente também abria para o público em geral, então ele fazia a exposição, a palestra para o grupo, mas com a comunidade toda assistindo também. E depois a gente ouvia os questionamentos, as perguntas da plateia para esse pesquisador e isso fazia parte também do processo de pesquisa nosso, de saber o quanto essa população, essas pessoas, tem de interesse sobre o assunto e como ela entende esse assunto. (Entrevista Coordenador).

O teatro com temática científica, no contexto do museu de ciências, parece congregar perspectivas do campo da divulgação científica, decorrente do local em que ele está inserido; da ciência, por tê-la como temática; da educação, por ter uma finalidade também didática; do campo da arte, por se constituir obra artística; e, no caso em estudo, no próprio público. As informações obtidas em cada um desses campos são articuladas durante a pesquisa artística e terminam por delinear a maneira com que o espetáculo será definido. Vale ressaltar a característica de dialogicidade desse processo, que pode encontrar identidade em pressupostos educacionais construtivistas e em modelos de comunicação pública da ciência mais contemporâneos. Entretanto, o coordenador não chega a mencionar diretamente quaisquer desses referenciais. 
Entrevistado: Todas as montagens começam com esse período de estudo, que vem pessoas externas ao projeto, à Estação Ciência, participam da discussão e daí vocês dão o start pra fazer o texto, é assim que funciona?

Entrevistado: Só não funcionou assim... As aulas espetáculos, " $O$ monocórdio de Pitágoras", "O professor Gervásio e a energia elétrica" e... É, principalmente esses dois. Esses dois nós fizemos mais "vamos sentar, vamos...". Aí "O professor Gervásio" nós, o professor Hamburger e o professor Gaspar lá da Universidade de Guaratinguetá, eles que nos ajudaram a criar essa situação sobre a energia elétrica e essa não foi levado dessa forma, foi mais direto. Só que aí a gente tinha claro que aula espetáculo é diferente de espetáculo. Um espetáculo, ele tem uma complexidade maior. Um espetáculo, ele trás os conflitos, desde o ser humano mesmo... E isso faz com que o espetáculo seja mais verdadeiro, seja mais intenso, seja mais humano, a aula espetáculo, para a gente, tava claro para gente também que era transformar só o assunto em algo mais divertido, mais cênico não tinha conflito. A aula espetáculo, ela ficava em cima de um tema, de um assunto, era a energia elétrica. A gente falava só sobre a energia elétrica, não tinha relação do professor Gervásio com a mulher, com os filhos, não tinha. Se ele estava desempregado, se ele estava... Não tinha nada disso, era lá e falava sobre a energia elétrica (Entrevista, turno 36, p. 26).

O coordenador define outra maneira de o espetáculo com temática científica se apresentar: a aula espetáculo. Essa modalidade é marcada por uma característica mais escolar, no sentido da preocupação estar mais centrada conceitos científicos e sua abordagem do que na característica artística. A verificação dessas duas possibilidades para o teatro com temática científica reforça a existência das vertentes já identificadas por Barbacci $(2002 ; 2004)$, quais sejam, o teatro usado como apoio didático para transmissão de conceitos científicos e a ciência emprestando seu conteúdo de ciência ao teatro. Na primeira possibilidade é contemplada melhor a categoria conceitos e conhecimentos da ciência e da tecnologia e, na segunda, seriam mais bem contempladas a natureza da ciência e da tecnologia e a relação entre ciência, tecnologia, sociedade e meio ambiente. Isso sinaliza que, em alguns casos, no NAC o teatro também é pensado e mobilizado para que se possa privilegiar a categoria conceitos e conhecimentos da ciência e da tecnologia.Importante problematizar que quando se tratou da aula espetáculo o conceito científico ficou em destaque e a participação do público na construção do espetáculo ficou diminuída. Esse procedimento assemelha-se às perspectivas mais tradicionais comunicação da ciência, centradas no conhecimento 
científico, na emissão da informação, e não na recepção (LEWENTEIN, 2003). As questões a respeito das problemáticas envolvidas na abordagem dos conceitos científicos continuam sendo discutidas:

O público que vem aqui, eu não sei se vai ser cientista, não sei se vai ter essa obsessão pelo conhecimento. E também não sei se é tão interessante ele sair daqui e falar "Não! É... A água é $\mathrm{H}_{2} \mathrm{O}$, o ar tem o oxigênio". Não sei se é tão interessante isso, mas, principalmente, saber que há sim possibilidades de conhecimentos sobre tudo isso. Aí, sim, aí a gente coloca ele numa situação, que eu acho bem interessante. De saber que o mundo pode se revelar pra ele. E a partir daí ele ter mais consciência sobre tudo isso. A se sentir mais dentro disso, se sentir incluído, se sentir, como uma pessoa que pode interferir, como uma pessoa que pode ser protagonista, como uma pessoa que pode dividir conhecimento, que pode, na busca, depois dividir. Porque uma pessoa que pode assumir com mais ênfase, com mais veracidade, com mais discernimento a sua cidadania, não vai ser uma pessoa que está sujeito a qualquer ideia, a qualquer pensamento. Ele vai ter, com certeza, vai ser uma pessoa, que "Não, peraí, opa!", se determinada situação lá, que eu vi, chegou a partir, dessa maneira, então aqui também deve ser isso! (Entrevista Coordenador)

A partir do relatado considera-se que, em geral, na prática do NAC o teatro com temática científica é proposto como maneira de contribuir para a alfabetização científica por estimular o desenvolvimento da liberdade intelectual, favorecendo o desenvolvimento da categoria natureza da ciência e da tecnologia. Nos espetáculos, os conhecimentos científicos e produções da ciência seriam utilizados para o desenvolvimento de faculdades intelectuais, favorecendo a apreciação da ciência e da tecnologia pela estimulação intelectual que elas podem suscitar. Com isso, pode-se favorecer no público o desenvolvimento da sensação de prazer intelectual quando em contato com um desafio científico. Nesse aspecto, há concordância com os autores (PELLA ET ALL, 1966; LAUGKSCH, 2000; SASSERON, 2011) que sinalizam para o desenvolvimento da liberdade intelectual como sendo um dos objetivos da alfabetização científica. O mesmo ocorre com respeito ao desenvolvimento de habilidades de tomada de decisão (SHEN, 1975; HURD, 1998; HOFSTEIN, AIKENHEAD e RIQUARTS, 1988; FOUREZ 1999), devido ao fornecimento de ilustrações dos procedimentos e etapas necessários a esta prática. Os procedimentos apresentados no enredo dos espetáculos funcionariam como modelos a serem utilizados pelo público quando se defrontassem com uma situação de tomada de decisão. 
A ideia de estímulo à liberdade intelectual volta a aparecer na fala do coordenador:

Porque se a gente fala em mitose, tal, tal, tal, é muito chato no teatro! Nossa! O cara vai sair e vai falar "Ai meu Deus do céu, onde eu vim? [...]" Mas se a gente pega e reúne as pessoas, aí de repente... Aí vai, um grupo de oito pessoas, tudo juntinhas. Aí você vai quebrando isso, vai formando quatro, aí dois grupos de quatro... Aí vai criando outro grupo, já dividindo em dois, já são quatro grupos, aí esses grupos espalhados e começam a interagir a se concentrar a expandir, aí a, é outra... Então é isso, o que eu acho muito importante mesmo, nesse processo todo, que não é um centro formal de educação, não é uma faculdade, não é uma escola, não é um ensino médio nada disso. É justamente colocar as pessoas nessa situação, de curiosidade, de buscar, se conscientizar, de buscar o conhecimento, de buscar determinada situação que revele o quanto ele pode ainda avançar mais. Esse lugar, é que é interessante para acontecer um espaço como a Estação Ciência, como o teatro, porque no teatro são duas horas no máximo, o quê que a pessoa vai aprender exatamente? A não ser que você, trabalhando nesses aspectos emocionais, aí sim despertar para essas possibilidades. E o desdobramento disso, de chegar a essa pessoa se formar, ser pesquisador, ou ser um ator, ou ser uma pessoa que contribua realmente com a sociedade, pensando que veio de possibilidades anteriores que o remeteram para esse estágio atual. Então a Estação Ciência, os Centros de Ciências, teatro, uma estória em quadrinhos cientifica ou uma exposição... É possibilitar mesmo a esse ser, a esse cidadão, esse "Ah, eu também posso!" "Ah, eu posso também?" “Ah, então eu vou!”, “Então eu quero!” (Entrevista Coordenador).

$\mathrm{Na}$ perspectiva do coordenador o teatro com temática pode ser uma maneira de atuar no estímulo ao apreço pela natureza da ciência, à admiração enquanto construto social. Além disso, proporciona elementos para mudanças de comportamento do público frente à ciência e seus conhecimentos, incluindo mudança na relação afetiva que, potencialmente, poderia favorecer o ingresso em carreiras científicas. Essas proposições estão em acordo com as discussões sobre alfabetização científica propostas por autores tais como Hazen e Trefil (1995), Laugksch (2000), Bybee (1987), Hurd (1998), Chassot (2003a), Cazeli (2001), Sasseron e Carvalho (2011) e Shen (1975). Este último, inclusive, propõe a existência de uma dimensão da alfabetização científica denominada de cultural, a qual motiva o desejo de conhecer a ciência de forma mais aprofundada e não se destina diretamente à resolução de problemas práticos. É uma apreciação da ciência enquanto construto humano. 
Do que emerge do relato do coordenador, com respeito à relação do teatro com outras atividades museais, em especial a exposição, há uma relação de complementariedade, na qual o teatro teria a característica de, além de abordar a alfabetização científica nas diferentes categorias teóricas que definimos, auxiliar as outras atividades nos ajustes que fossem necessários. No que se refere às categorias teóricas, foi perceptível ao longo do relato a perspectiva de se privilegiar as categorias natureza da ciência e da tecnologia e a categoria relação entre ciência, tecnologia, sociedade e meio ambiente.

\section{d) A exposição}

No ano de 2006 a Estação Ciência submeteu o projeto intitulado $A$ invenção de Santos Dumont - os princípios que permitiram a construção do 14 BIS ao Edital MCT/CNPq no 12/2006 - Difusão e Popularização da Ciência e Tecnologia. O projeto foi aprovado no Processo n ${ }^{\circ} 553477 / 2006-4$. O principal objetivo do projeto, conforme documento enviado ao $\mathrm{CNPq}$, era estruturar ações que colocassem em discussão os princípios que possibilitaram o voo, focalizando referencias no mundo natural (aves, insetos, sementes etc.) e em aspectos tecnológicos, tendo como ponto central o primeiro voo do 14 BIS (23 de outubro de 1906). Os objetivos específicos congregavam a construção de uma exposição temática e interativa e de um espetáculo teatral (até então denominado de Aquele que viu o que ainda veremos), bem como a itinerância da exposição por centros de ciências de outras regiões do país.

As ações do projeto previam destacar os aspectos históricos, biológicos e físicos que possibilitaram o voo por meio dos subtemas: (i) as visões mitológicas do voo, (ii) os primeiros desenhos e projetos de máquinas de voar, (iii) as estruturas encontradas na natureza (aves, sementes e insetos), (iv) os balões, (v) a vida e obra de Santos Dumont, (vi) os conceitos aerodinâmicos, (vii) as condições externas ao voo, (viii) o avião depois do 14 BIS, (xix) os esportes de voo e (x) as viagens espaciais.

Na observância dos subtemas a serem contemplados depreende-se a possibilidade de o conjunto das ações (exposição e espetáculo) abordar a ciência e a tecnologia na completude anunciada pela alfabetização científica. Percebe-se que os subtemas ii, iv, v e viii favorecem os conhecimentos a respeito da natureza da ciência e da tecnologia. Já os subtemas iii, vi e vii possibilitam a abordagem de conhecimentos e conceitos básicos 
da ciência e da tecnologia. E, por fim, os subtemas i, xix e x incitam a exploração da relação entre ciência, tecnologia, sociedade e meio ambiente.

Já apresentamos quais aspectos da alfabetização científica estiveram presentes no produto espetáculo teatral. Nesse momento explicitaremos quais aspectos da alfabetização científica estiveram presentes no produto exposição. A análise que realizaremos da exposição fundamenta-se nas informações obtidas por meio do Relatório Técnico enviado ao $\mathrm{CNPq}$, a respeito dos resultados alcançados no projeto, cedido pela coordenadora do projeto, Profa. Dra. Roseli de Deus Lopes.

A exposição construída foi nomeada de $A$ invenção de Santos Dumont e foi divida em três propostas, exposição temporária, exposição itinerante e escultura interativa. A exposição temporária ficou montada na Estação Ciência durante 10 meses, atingindo um público de cerca de 208.000 pessoas, dentre escolares da rede pública e privada, bem como a população em geral. Tinha como finalidade principal divulgar os feitos de Santos Dumont, seus projetos, e seu pioneirismo como designer. Contava com os seguintes elementos expositivos:

Pioneiros do Céu

Descrição: Vitrine com miniaturas-réplicas de aviões brasileiros. Constituída por onze maquetes, uma grande hélice de madeira, painéis e informações históricas sobre o desenvolvimento da aviação, da indústria aeronáutica brasileira, os bastidores da construção da tecnologia aeronáutica desde o advento 14 bis até o auge internacional da Embraer (Relatório Técnico). 


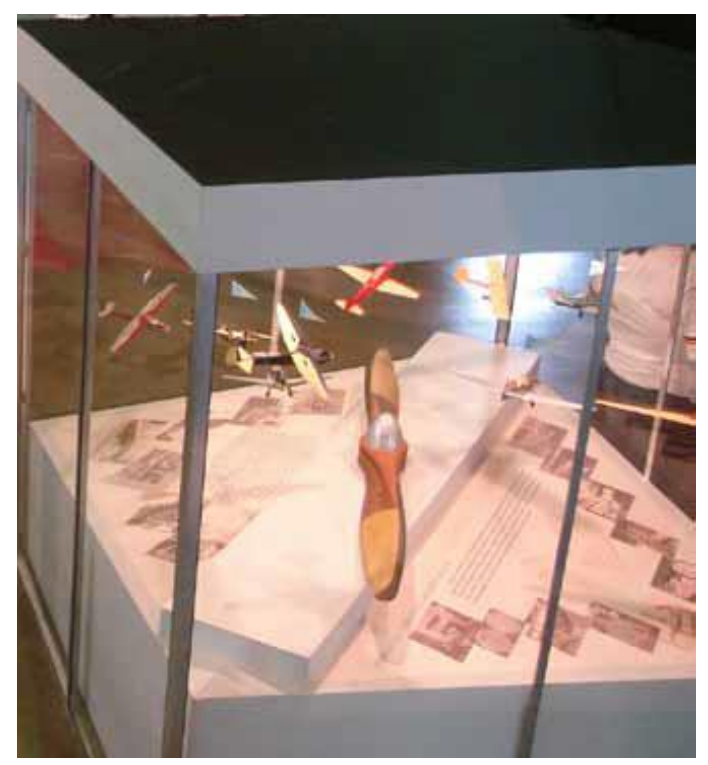

Figura 4.7: Vitrine Pioneiros do céu.

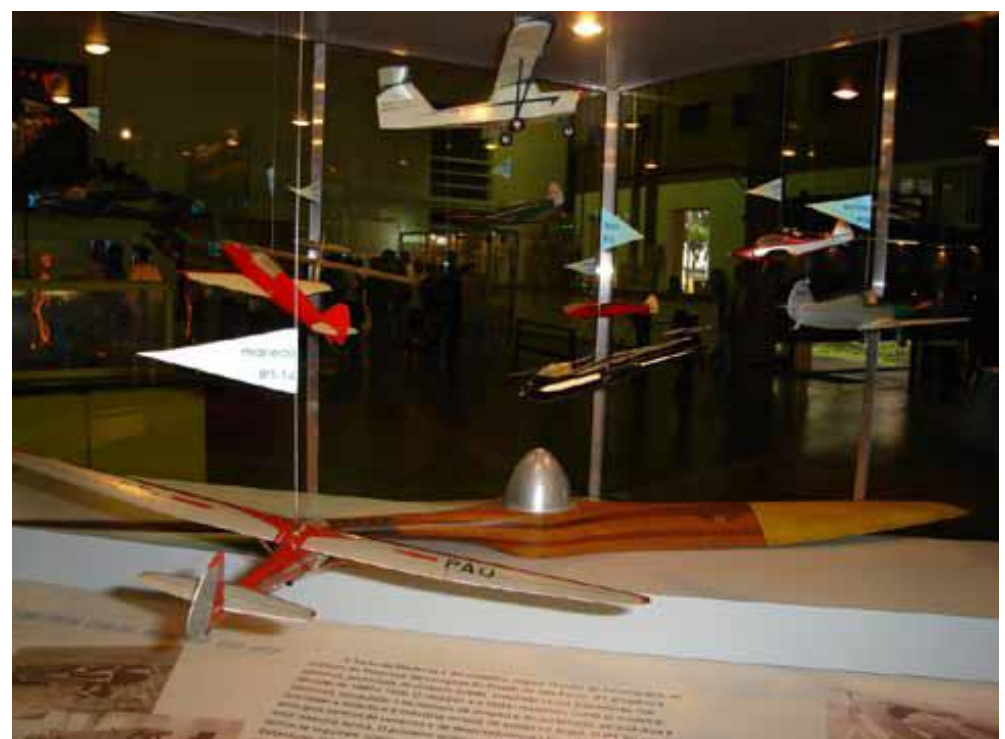

Figura 4.8: Vitrine Pioneiros do céu. 
Considerando a descrição e as imagens a respeito da vitrine Pioneiros do Céu, constantes no relatório técnico, percebe-se que esse aparato está centrado em focalizar informações com respeito à categoria natureza da ciência e da tecnologia, uma vez que apresenta a história do desenvolvimento da aviação e da indústria aeronáutica brasileira. Essa mesma categoria é privilegiada também quando se observa a réplica do Demoiselle, uma vez que nele é a apresentado um objeto da tecnologia, o próprio Demoiselle.

Demoiselle

Descrição:Réplica em tamanho real do avião Demoiselle confeccionada pelo aviador Ruy de Azevedo Sodré Sobrinho. O Demoiselle original foi construído em 1907 e é considerado uma das mais belas concepções de Santos Dumont. A exposição ainda conta com nove banners abordando as invenções de Santos Dumont.

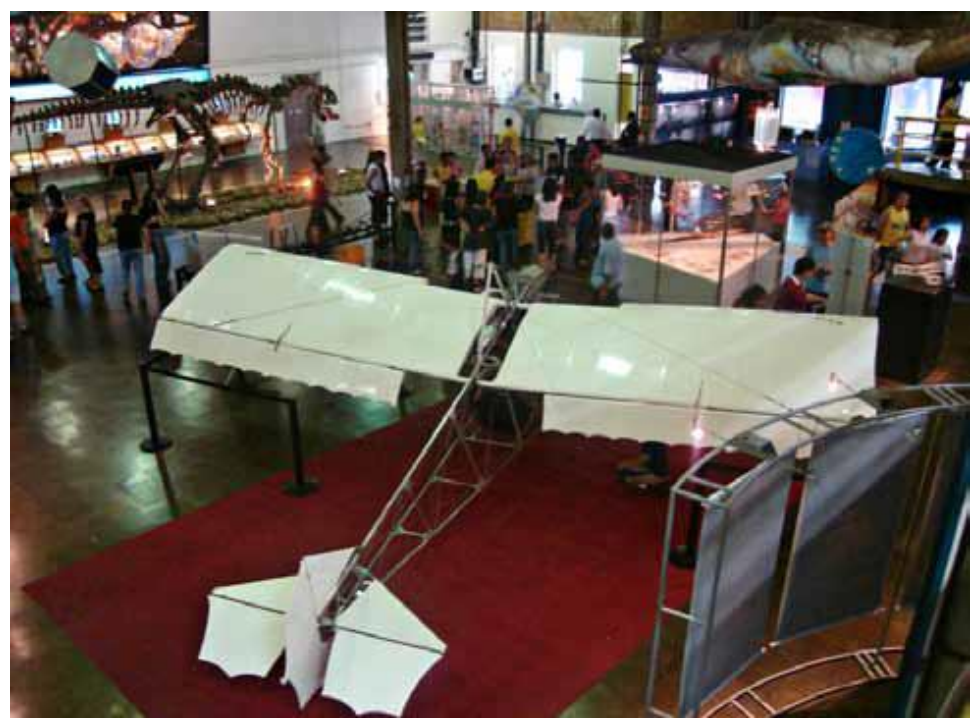

Figura 4.9: Réplica Demoiselle. 


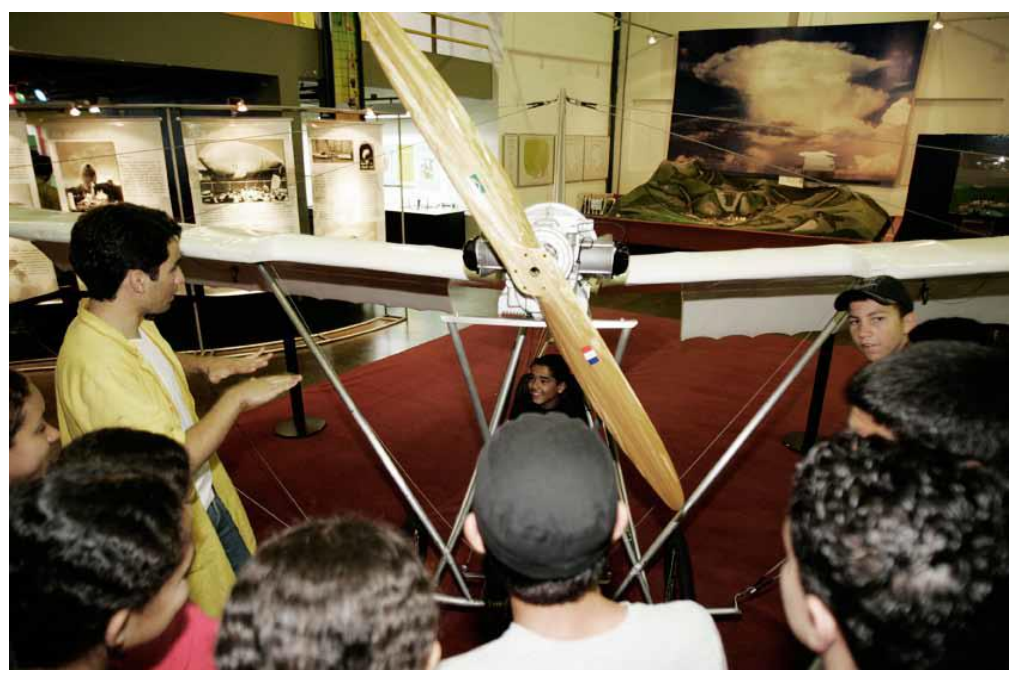

Figura 4.10: Réplica Demoiselle.

A categoria conhecimentos e conceitos básicos da ciência e da tecnologia está presente na exposição itinerante. Esta foi constituída de equipamentos (ajustados como experimentos interativos), abordando conceitos da física relacionados com o tema da exposição (figura 4.11 e 4.12).

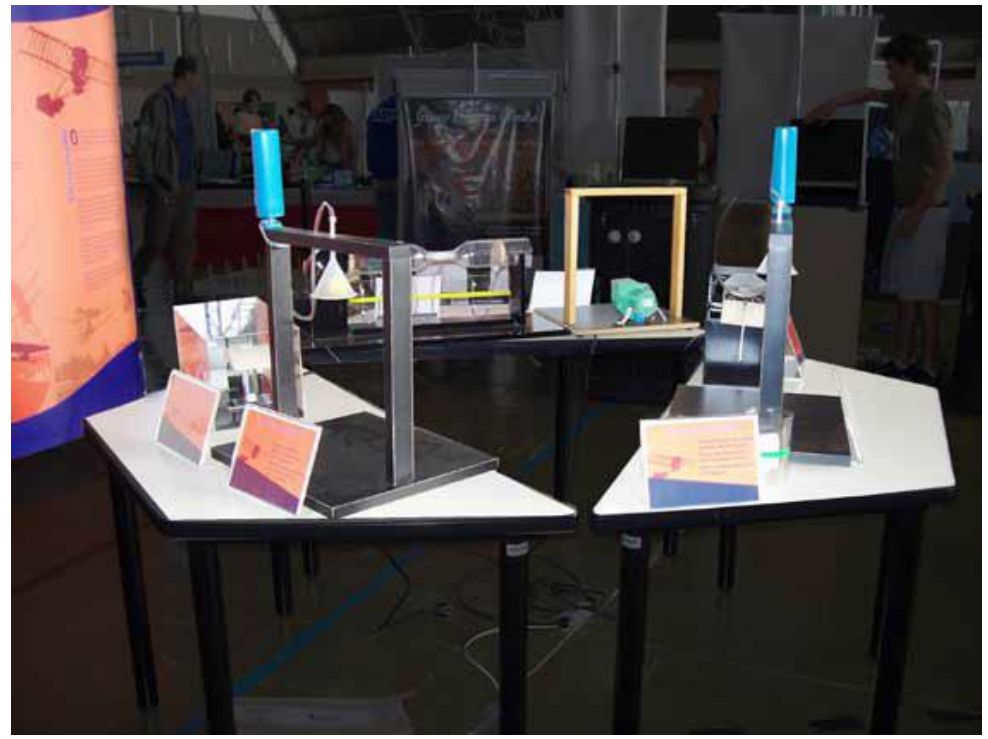

Figura 4.11: Equipamentos. 


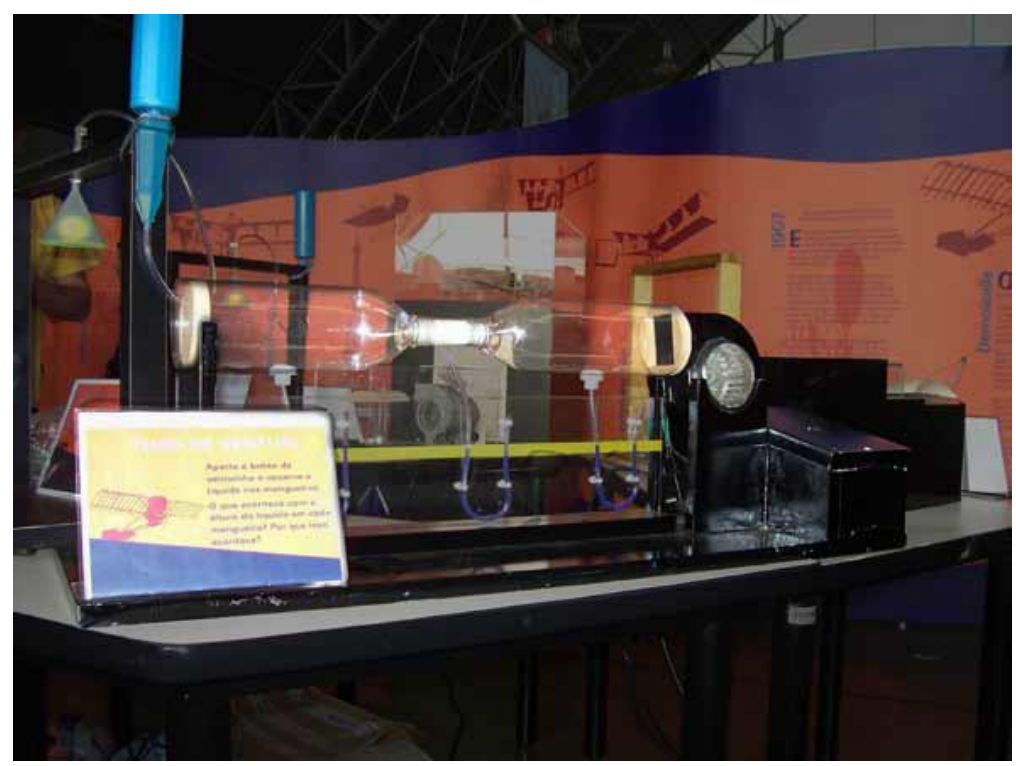

Figura 4.12: Equipamentos.

Os equipamentos constantes na exposição itinerante foram denominados de asa na garrafa, tubo de Venturi, efeito coanda, bola flutuante, túnel de vento, diferença de pressão e jato de ar.

\begin{abstract}
Asa na Garrafa
Descrição:O visitante deverá soprar o tubo mudando o ângulo de inclinação até que a asa dentro do tubo voe. A sustentação de uma asa depende, além de outros fatores, da velocidade e ângulo de ataque da asa. $\mathrm{O}$ aumento do ângulo de ataque aumenta a sustentação somente até um determinado ponto. Após este ângulo ótimo, acontece literalmente o descolamento do fluxo de ar e a aeronave perde a sustentação. É o estol, que se ocorrer em baixas altitudes pode levar a aeronave ao chão (Relatório Técnico).
\end{abstract}

O equipamento Asa na Garrafa é acompanhado por um display no qual se lê Assopre o tubo mudando o ângulo de inclinação. O que acontece com a asa? Ela sempre voa? Qual o melhor ângulo de inclinação? (Relatório Técnico). A partir da observação da descrição do equipamento e das perguntas constantes no display percebese que esse equipamento proporciona que se contemple a categoria conhecimentos e conceitos básicos da ciência e da tecnologia. Conforme se percebe, na interação com esse aparato torna-se necessário pensar e discutir conceitos tais como ângulo de ataque, ângulo ótimo, velocidade, deslocamento de fluxo de ar e estol. 
No Tubo de Venturi os conceitos abordados são os relativos ao comportamento do ar ao passar pela asa de um avião:

Tubo de Venturi

Descrição: O intuito deste equipamento é demonstrar o comportamento do ar ao passar pela asa de um avião mostrando as diferenças de pressão em diferentes pontos da asa. O mesmo volume de ar que passa na primeira seção do cano (a), passa pela segunda (b), portanto a velocidade do ar na seção b é maior que em a. A experiência de Bernoulli demonstra que numa seção onde a velocidade do ar é menor, a pressão em suas paredes é maior e onde a velocidade do ar é maior a pressão é menor. Em 1738 o físico suíço Bernoulli descobriu que a pressão exercida por um fluido sobre a parede de um tubo decresce à medida que aumenta a velocidade de escoamento (Relatório Técnico)..

No display que acompanha o equipamento Tubo de Venturi lê-se Aperte o botão na ventuinha e observe o líquido nas mangueiras. O que acontece com a altura do líquido em cada mangueira? Por que isso acontece? (Relatório Técnico). A partir desse equipamento se propõe a discussão da relação entre pressão e velocidade do ar. No equipamento Efeito Coanda se abordam conhecimentos referentes ao comportamento dos fluidos:

\section{Efeito Coanda}

Efeito Coanda é a tendência de um fluido acompanhar a curvatura de uma superfície. Este efeito é usado para aumentar a sustentação fornecida pelos flapes. $\mathrm{O}$ ar comprimido pode ser forçado através de grandes aberturas na parte superior da asa para produzir sustentação extra. Henri Marie Coanda (19886-1972), engenheiro e inventor areonauta francês nascido na Romênia, descobriu este efeito em 1910 ao observar que os gases em combustão que saíram dos reatores laterais do avião circulavam junto e ao longo da fuselagem, do avião, ao invés de saírem em linha reta (Relatório Técnico).

No display desse equipamento lê-se sopre o ar sobre a bolinha utilizando a bomba manual. Observe o que acontece com a bolinha. Por que isso acontece? (Relatório Técnico). Também no equipamento Bola Flutuante se discute sobre o comportamento dos fluidos, mais especificamente linhas de corrente de fluidos (efeito Magnus). O display desse equipamento procura estimular o estabelecimento dos conceitos de comportamento dos fluidos, pressão, ângulo e força: incline o jato de ar com a bola suspensa. Será que a bola acompanha o jato de ar? Até qual ângulo se pode movimentar o jato de ar? (Relatório Técnico). 
Conceitos relativos à pressão são novamente trabalhados nos equipamentos Tunel de Venturi, Diferença de Pressão e Jato de Ar.

Túnel de Venturi - Ao ligar o motor, o fluxo de ar acima da asa gera uma diferença de pressão. A asa voava acompanhando a guia instalada na base do equipamento. (Relatório Técnico).

Diferença de Pressão - Temos a demonstração da diferença de pressão novamente em um perfil de asa. Esta variação da pressão suga a bolinha através do tubo (Relatório Técnico).

Jato de Ar - Ao passar o jato de ar pelas bolinhas a diferença de pressão provoca o deslocamento, fazendo com que elas se toquem constantemente (Relatório Técnico).

Nesses três equipamentos as informações no display envolviam instruir o visitante a ligar uma ventuinha, observar e depois explicar o porque do que ocorria.

Havia também uma instalação interativa, denominada de Escultura Interativa(figuras 4.18, 4.19 e 4.20 ).

A escultura interativa é uma plataforma que reproduz mecanicamente, em escala reduzida (com manipulação dos visitantes ou de monitores da exposição), a trajetória de 60 metros do primeiro voo do 14 BIS, em 1906. A escultura ilustra também o conceito de voo do 14 bis, voo canard - leme à frente, motor e asas atrás(Relatório Técnico). 


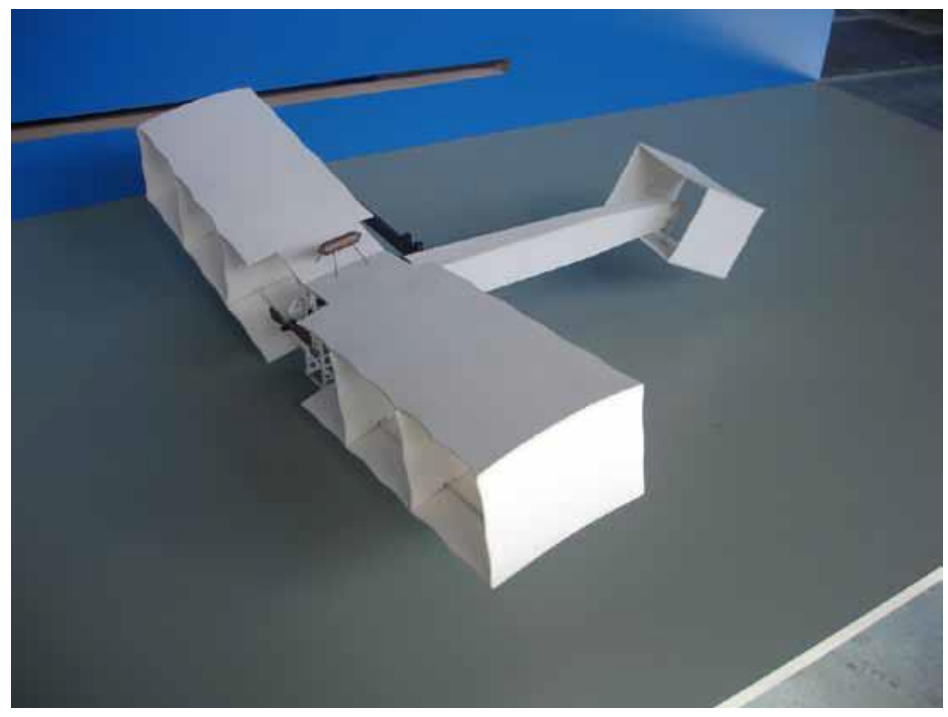

Figura 4.13: Voo 14 bis.

A escultura interativa, mais uma vez, possibilita a abordagem da categoria natureza da ciência e da tecnologia por colocar em foco um produto/objeto tecnológico, possibilitando ao visitante conhecimentos sobre os resultados da tecnologia. A escultura interativa contava com um painel contendo informações e fotos.

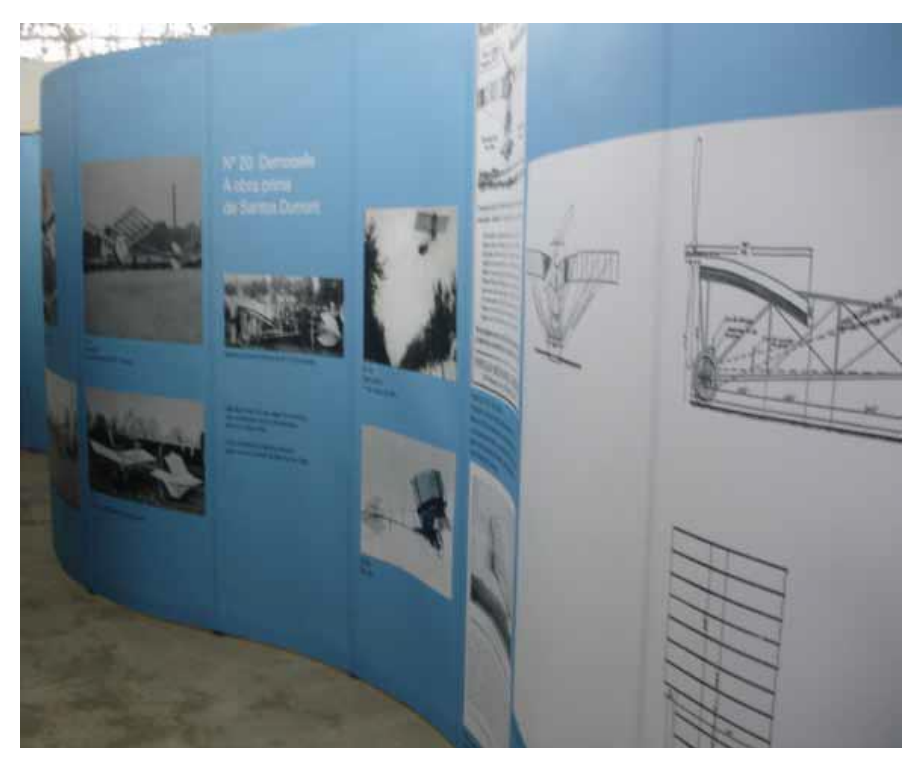

Figura 4.14: Voo 14 bis.

No que se percebe, a partir das informações contidas no Relatório Técnico, a exposição se ocupou de mostrar projetos, desenhos, maquetes e réplicas relativas ao voo e aos trabalhos desenvolvidos por Santos Dumont. Na abordagem desses elementos a 
preocupação passou por elucidar ao público o desenvolvimento da aviação e da indústria aeronáutica brasileira, explicitando bastidores do desenvolvimento tecnológico. Essa perspectiva proporcionou a abordagem da categoria natureza da ciência e da tecnologia. Constatou-se, também, a abordagem de conhecimentos e de conceitos científicos e tecnológicos envolvidos na aviação, principalmente na parte itinerante, por meio dos equipamentos que os próprios visitantes manipulavam, contemplando a categoria conhecimento e conceitos da ciência e da tecnologia. Por fim, a categoria relação entre ciência, tecnologia, sociedade e meio ambiente também é contemplada, com foco maior na relação entre ciência e tecnologia. 


\section{CONSIDERAÇÕES FINAIS}




\section{1 - O Teatro no Museu e a Alfabetização Científica}

Nesta pesquisa tivemos como motivação o desvelar de como o teatro realizado pelos Museus e Centros de Ciências (MCC) dialoga com a perspectiva da alfabetização científica (AC). Nesse sentido, nos preocupamos em produzir conhecimentos, por meio de estudo exploratório, de estudo de caso e da análise da literatura, a respeito do surgimento do teatro enquanto atividade museal e seu papel nos MCC.

A análise do Núcleo de Artes Cênicas da Estação Ciência (NAC) demonstrou que o teatro, uma das possibilidades de atividades museais, pode ser pensado e organizado para se abordar as perspectivas da alfabetização científica. Contudo, foi perceptível que no caso estudado, tanto no momento da construção da exposição quanto do espetáculo teatral que não havia um pensamento explicitamente consolidado e estruturado em referências e teorias a respeito da alfabetização científica. Apesar disso, foram identificadas no planejamento da exposição e do espetáculo teatral preocupações com a maneira com que a ciência e a tecnologia seriam abordadas, que remetiam às problemáticas que constituem o bojo das discussões sobre a alfabetização científica.

A proposta de alfabetização científica percebida no NAC contempla, com mais ênfase, as dimensões natureza da ciência e a relação entre ciência, tecnologia, sociedade e meio ambiente. A dimensão conceitos e conhecimentos básicos da ciência e da tecnologia é contemplada em menor intensidade, salvo nos momentos em que o NAC se mobilizou para construir as denominadas "aulas espetáculo". Estas têm como foco principal a discussão de conceitos científicos e tecnológicos junto ao publico. Especificamente com respeito ao espetáculo analisado (Larguem Tudo! Vamos Voar!) os diversos sistemas cênicos são mobilizados na abordagem das diferentes dimensões da alfabetização científica conforme demonstramos em nossos resultados e discussão, contribuindo para a construção de ideias a respeito da ciência e da tecnologia.

No que se refere ao Texto da Peça, os dados referentes a analise deste documento apontam que sua contribuição promove a abordagem da dimensão natureza da ciência, em especial por explorar e reforçar a perspectiva de ciência e tecnologia como produtos do intelecto humano, ou seja, são realizadas e construídas por pessoas e, por isso, podem ser influenciadas por características dessas pessoas. Assim, o Texto da Peça veicula a imagem de um homem de ciência humano, inventivo e curioso, que se 
deixa encantar por um fenômeno e que é tenaz em seu objetivo de desenvolver estudos e experimentos. Outra característica do Texto da Peça que favorece a abordagem da natureza da ciência e da tecnologia são as discussões a respeito dos produtos tecnológicos, tais os balões e o relógio de pulso, e o estímulo à liberdade intelectual. Em menor intensidade o Texto da Peça aborda a dimensão relação entre ciência, tecnologia, sociedade e meio ambiente e a dimensão conhecimentos e conceitos básicos da ciência e da tecnologia. No que se refere a esta última, os conceitos científicos e tecnológicos foram abordados de maneira a se constituírem como um dos elementos do espetáculo, para o entendimento da fábula, sem uma abordagem conceitual aprofundada. A encenação do espetáculo, na sua mobilização de outros sistemas cênicos, acrescenta e reforça a dimensão mais fortemente contemplada pelo Texto da Peça, qual seja, natureza da ciência e da tecnologia. Nesse sentido, cenário, música de cena, iluminação, voz, corpo e figurino auxiliam na construção do homem de ciência como pessoa, apresentando e dando continuidade aos pensamentos, sentimentos e emoções de Dumont. Já a sonoplastia e os objetos de cena reforçam a ideia de homem de ciência como um experimentador, alguém que desenvolve um trabalho manual de construção de coisas.

Com respeito à relação do teatro com outras atividades museais, em especial a exposição, há uma relação de complementaridade, na qual o teatro teria a característica de, além de abordar a alfabetização científica nas diferentes categorias teóricas definidas nessa pesquisa, auxiliar nos ajustes que fossem necessários. Os resultados encontrados em nosso estudo de caso permitem entender melhor como essa dinâmica é possível.

$\mathrm{Na}$ análise sobre as dimensões da alfabetização científica realizada sobre o espetáculo em si, a partir do vídeo com a filmagem da peça, verificou-se que a mesma contempla visões mitológicas do voo, nos momentos em que aborda a história de Ícaro, inclusive estabelecendo uma relação entre o desfecho da vida de ícaro e de Dumont. Com respeito às estruturas encontradas na natureza a trama focaliza os pássaros, na dimensão da admiração e de inspiração para a construção de aparatos mecânicos. Os balões aparecem na função de ilustração das invenções de Dumont. Já a vida e obra de Santos Dumont são abordados extensamente, ressaltando as características atribuídas ao homem Santos Dumont, sua trajetória e suas invenções. Assim, o espetáculo teatral contemplou com maior intensidade os aspectos relativos à 
natureza da ciência e da tecnologia e a relação entre ciência, tecnologia, sociedade e meio ambiente, conforme descrevemos.

A exposição, por sua vez, focalizou as discussões nos projetos, desenhos, maquetes e réplicas relativas ao voo e aos trabalhos desenvolvidos por Santos Dumont, bem como no desenvolvimento da aviação e da indústria aeronáutica brasileira, proporcionando também a presença da abordagem da categoria natureza da ciência e da tecnologia. A categoria conhecimentos e conceitos científicos e tecnológicos foi contemplada nos conceitos científicos e tecnológicos envolvidos na aviação, presentes na parte itinerante da exposição, o que foi identificado por meio do Relatório Técnico da mesma. A categoria relação entre ciência, tecnologia, sociedade e meio ambiente esteve presente na própria relação que a exposição estabelece entre os conceitos científicos e a tecnologia, visando abordar o advento da aviação.

A prevalência da categoria natureza da ciência e da tecnologia é uma importante contribuição do teatro realizado nos MCC, considerando que o processo de alfabetização científica é contínuo e acontece ao longo da vida, iniciando-se nas instâncias formais, e que essas instâncias formais ainda são marcadas fortemente pela abordagem de conceitos científicos e não da ciência como uma produção humana. Nesse sentido, o teatro no museu de ciências apresenta a ciência como parte da vida, isto é, dentre as várias atividades desenvolvidas por uma pessoa estaria a atividade científica. A divulgação dessa visão de mundo é motivadora para os jovens que ainda ingressarão em uma carreira profissional, uma vez que desconstrói a concepção corrente de ciência como sendo um lugar apessoal, no qual os desejos que se realizam são os da ciência, dos cálculos, das fórmulas, dos conceitos etc. e não os do cientista.

Contudo, considerando que novos conhecimentos são produzidos diariamente e que as instâncias formais de educação têm dificuldades de incorporar os conhecimentos mais recentes em seus currículos, há que se considerar que uma abordagem mais estruturada dos conhecimentos e conceitos científicos e tecnológicos também seria promissora. A conscientização quanto as dúvidas, as incertezas e as confabulações próprias aos homens de ciência no momento em que estão construindo um conceito científico ou tecnológico, bem como do desfecho, possibilitam o conhecimento conceitual desses construtos, porém continuam favorecendo a visão humana de ciência. Além disso, nesses moldes pode-se contemplar melhor os aspectos da alfabetização científica referentes ao conhecimento dos conceitos da 
ciência e da tecnologia sem que o teatro se perca em uma encenação escolar, excessivamente didática.

\section{2 - Teatro e Exposição nos Museus e Centros de Ciências: Possíveis Articulações}

Por meio da análise conjunta da peça teatral e da exposição foi perceptível que a distribuição entre a encenação e a exposição dos conceitos e aspectos relacionados ao tema do Vôo e da vida de Santos Dumont, assim como das dimensões da $A C$ não é rígida, já que o fato de uma informação ou aspecto da temática aparecer em uma estratégia não impediu que o mesmo aparecesse na outra. Constatou-se que tanto a encenação quanto a exposição contemplaram as questões referentes à natureza da ciência e da tecnologia, os conhecimentos e conceitos científicos e tecnológicos e a relação entre ciência, tecnologia, sociedade e meio ambiente. Contudo, percebem-se nuances na abordagem das dimensões da AC nos dois elementos de análise. Por exemplo, enquanto o espetáculo aborda a natureza da ciência e da tecnologia na perspectiva do homem de ciência, focalizando suas características e sonhos, a exposição aborda o mesmo assunto pelo viés das produções, dos equipamentos e das dinâmicas da comunidade científica. Nesse sentido entende-se que as estratégias, em alguns momentos, assumem o aspecto de complementaridade. O mesmo pôde ser percebido quanto ao próprio assunto. Verificou-se que espetáculo centra sua lente sobre a aviação na figura de Santos Dumont. Já a exposição, em complementaridade, enfatiza o período pós Santos Dumont, chegando a discutir sobre a história da aviação brasileira.

Em nosso estudo exploratório encontramos que o Teatro surge nos MCC devido à solicitação do público infantil por atividades diferentes, demanda explicitada nos livros de sugestões das instituições que participaram dessa etapa da pesquisa, e também devido à expectativa de que essa atividade possibilitaria despertar nos jovens e nos adultos o interesse pela ciência, dinamizar a divulgação científica e ampliar a comunicação das exposições. Dois outros fatores contribuem para esse surgimento: a necessidade de diversificar a forma de comunicação da ciência e o ambiente favorável à incorporação do Teatro enquanto linguagem possível dentro dos MCC (resultante da disponibilidade de profissionais do campo das artes cênicas e de sujeitos não atores dispostos a apreender e utilizar essa linguagem). Em concordância com esses dados, encontramos em nosso estudo de caso o surgimento do Núcleo de Artes Cênicas da 
Estação Ciência atrelado à disponibilidade de um profissional de artes cênicas (que se tornou coordenador do projeto no período 1999-2012) e a proposição da direção da Estação Ciência, à época, em incorporar o teatro visando à diversificação das atividades museais.

O teatro surgido e realizado nos MCC é caracterizado por assumir nuances diversas, tais como esquetes, improvisações, performances, contação de história, dentre outras. Em alguns casos é realizado por companhias contratadas e, em outros, os MCC contam com uma equipe que desenvolve a atividade, sendo a formação das pessoas que compõem essas equipes bastante diversa, passando por estudantes de graduação e de pós-graduação, bibliotecários, químicos, biólogos, físicos, pedagogos, profissionais do campo das artes cênicas, museólogos e outros. A periodicidade das ações teatrais é variável entre permanente ou eventual, podendo haver uma relação direta com a temática da exposição. A motivação para o desenvolvimento das atividades é a necessidade de despertar nos jovens e adultos o interesse pela ciência, de dinamizar a divulgação científica e de ampliar a comunicação das exposições.

Assim, o teatro é mais uma entre as possibilidades de divulgação científica em museus, podendo estar articulado com outras ações no sentido de complementariedade, com cada uma delas reforçando um aspecto da AC. Nesse contexto, olhar o teatro dentro do museu significa também perceber indícios de como essa instituição se organiza pedagogicamente, articulando teatro, coleções ou demais ações educativas.

\section{3 - O Teatro no Museu: Arte, Educação ou Divulgação} Científica?

No estudo do teatro enquanto ação museal encontramos que essa prática é marcada por um conflito: ser ou não ser obra de arte. Uma obra de arte é um fenômeno revelador e constitutivo da vida e do ser humano. Ela constrói realidades e sentidos, cujas dimensões não se limitam às proposições (ou intenções) de outros construtos (BIÃO, 2009). Nesses moldes o teatro realizado em MCC não poderia ser entendido como obra de arte, pois ele estaria se subjugando às proposições de divulgação da ciência. Contudo, Bião (2009) prossegue ponderando que, momentaneamente, a arte pode submeter-se a quaisquer construtos, reduzindo temporariamente suas dimensões artísticas às dimensões do imaginário e do simbólico dos discursos de outro campo 
específico sem diluir-se completamente. E, nessa acepção, o teatro realizado em MCC pode ser considerado como obra de arte.

No relato do coordenador do projeto encontramos que a preocupação do NAC foi se tornando a construção de uma obra artística e não uma simples estratégia para falar da ciência. Inicialmente, o teatro foi tido como instrumento para a divulgação da ciência, sendo mobilizado para atender aos interesses e às proposições desse campo. No decorrer dos trabalhos desenvolvidos por esse núcleo é que a relação entre teatro e ciência foi sendo repensada e a acepção simples de veículo para a divulgação científica foi sendo desconstruída. $\mathrm{O}$ contato do fazer teatral com a ciência foi resultando no reconhecimento de que o teatro constitui-se, também, como campo de produção de conhecimentos. Em decorrência disso, o núcleo se estrutura para a produção de obras artísticas que abordem temáticas científicas. Com isso diversos espetáculos do NAC se propõem a revelar a vida e o ser humano, sendo a ciência e a tecnologia uma parte da vida. Aqui a dimensão cultural da Ciência parece ganhar destaque.

Nos teatro com temática científica, além da preocupação artística há a preocupação com a informação científica, assim a liberdade poética termina por ser limitada pela necessidade de clareza e precisão da comunicação da informação científica. O espetáculo não poderia se furtar de comunicar as concepções, as perspectivas e as informações academicamente aceitas. Para isso, é necessário o estabelecimento de uma parceria e comprometimento do artista com a ciência. Essa dinâmica diferenciada é uma característica do fenômeno teatro com temática científica.

Entretanto a liberdade poética se mantém presente tanto na maneira como a informação científica será comunicada, isto é, o teatro pode acontecer em diferentes possibilidades de encenação que o artista pode optar para a comunicação da informação científica, quanto nos questionamentos e proposições possíveis a partir dessa informação, que passam pelo estranhamento do cotidiano e pelas novas visões de mundo que o artista pode construir (ou estimular a plateia a construir).

Outro aspecto que encontramos como característico do teatro realizado nos MCC, decorrente mesmo das motivações que o levaram a existir, é a proposição educativa. Nesse sentido, essa prática assume delineamentos do teatro didático (KOUDELA, 1991). Nesse, os procedimentos de construção dos personagens e do próprio espetáculo em si favorecem a aprendizagem em ciências e em tecnologia dos 
atuantes. Mais, potencialmente, os espectadores podem se beneficiar quanto aos conhecimentos e discussões sobre ciência e tecnologia presentes no espetáculo.

Em nossa revisão a respeito do teatro científico sinalizamos que esse termo não era adequado para nomear a prática do teatro que aborda temáticas científicas. Naquele momento nossos argumentos se fundamentavam em dois posicionamentos. O primeiro, de que o teatro científico tem sido utilizado para se referir a práticas teatrais que contemplam somente as ciências ditas da natureza, assim o termo era equivocado, pois desconsidera a existência de outras ciências que não sejam estas. O segundo, de que o termo teatro científico ignora a existência do teatro enquanto campo próprio, que produz conhecimento. Este sim podendo ser adjetivado de teatro científico. Os dados coletados nesta pesquisa reforçam a necessidade de promover adequações do termo teatro científico, uma vez que demonstraram o movimento de conscientização a respeito dessa problemática que foi surgindo na própria prática do NAC. No contato com a ciência e seus procedimentos foi sendo desenvolvida a percepção de que o próprio teatro possui interesses no que se refere a problemáticas de investigação, de procedimentos, de métodos e, por isso, constitui-se como um campo de produção de conhecimento. É possível perceber na história do projeto a modificação de teatro enquanto divulgador da ciência para teatro enquanto campo de pesquisa. No final do projeto a proposição era de que a pesquisa teatral andasse ao lado e à par com a temática científica.

Desse modo, ao nosso ver, o Teatro no museu possui grande potencial de se tornar ao mesmo tempo instrumento de divulgação, de educação e obra de arte. Também essas experiências, se realizadas de forma reflexiva sobre seu papel e função nesses espaços, permite uma profunda análise sobre a relação entre teatro e museu enquanto campo de investigação. 
REFERÊNCIAS BIBLIOGRÁFICAS 
ABREU, A. R. P., Estratégias de desenvolvimento científico e tecnológico e a difusão da ciência no Brasil (In) CRESTANA, S.(Org.) Educação para a ciência: curso para treinamento em centros e museus de ciência. São Paulo: Editora Livraria da Física, 2001, p. 23-28.

ACEVEDO, J.A. Educación tecnológica desde uma perspectiva CTS. Una breve revisión del tema. Alambique, 3, pp. 75-84, 1995.

ACEVEDO, J. A. La tecnología en las relaciones CTS. una aproximación al tema.Enseñaza de las ciencias, v. 14, n. 1, p. 35-44, 1996.

ACEVEDO, G. D. R. Análisis de algunos criterios para diferenciar entre ciencia y tecnología, Enseñanza de las Ciencias, 1998, 16 (3), 409-420.

AIKENHEAD, G. S. (1990). Science-technology-society Science education development: from curriculum policy to student learning. Brasília: CONFERÊNCIA INTERNACIONAL SOBRE ENSINO DE CIÊNCIAS PARA O SÉCULO XXI: ACT Alfabetização em ciência e tecnologia, 1; jun/1990.

AIKENHEAD, G. STS Education: A rose by any other name. In R. Cross (Ed.), A vision for science education: Responding to the work of Peter J. Fensham (pp.59-75). New York: RoutledgeFalmer Press, 2003.

ALVES, D. R. S.; PASSOS, M. M.; ARRUDA, S. de M. A educação não formal em periódicos da área de Ensino de Ciências no Brasil (1979-2008). Revista Brasileira de Educação Científica e Tecnológica. Vol. 3, n 1, jan/abr, p. 16-40, 2010.

ARONS, A. B. Achieving Wider Scientific Literacy. Daedalus, n 112, p. 92-93, 1983.

AULER, D.; DELIZOICOV, D. Alfabetização científico-tecnológica para quê?. ENSAIO - Pesquisa em Educação em Ciências, vol. 3, n 1, jun, 2001, p. 105-115.

ARONS, A. B. Achieving Wider Scientific Literacy. Daedalus, n 112, p. 92-93, 1983.

AULER, D. Alfabetização científico-tecnológica: um novo paradigma? Ensaio pesquisa em educação em ciências , v.05 n.1, p. 12-25, 2003.

BARATA,G. Notícias do Mundo: Museus devem divulgar ciência com emoção. Ciência e Cultura. Vol.55, n. 2, São Paulo, Abr./Jun, 2003, p. 16-17.

BARBACCI, Silvana. From the Golem to Artificial Intelligence: science in the theatre for an existential reflection. Journal of science communication. v. 01, issue 03, september, 2002. Disponível em: http://jcom.sissa.it/archive/01/03/A010304/?searchterm=None/. Acessado em: 28/03/2011.

BARBACCI, S. Science and Theatre: a multifaceted relationship between pedagogical purpose and artistic expression. 8th International Conference on Public Communication of Science and Technology, 2004. Disponível em http://www.pantaneto.co.uk/issue19/barbacci.htm. Acessado em: 01/05/2011.

BARDIN, L. Análise de conteúdo. Lisboa: Edições 70, 2000.

BATISTETI, C. B.; ARAUJO, E. S. N. N. e CALUZI, J. J. Os experimentos de Griffith no ensino de biologia: a transposição didática do conceito de transformação nos livros didáticos. Ensaio, v.12, n.01, p.83-100, jan-abr, 2010. 
BERNARDO, J. R. R.; VIANNA, D. M.; FONTOURA, H. A. da Produção e Consumo da Energia Elétrica: a construção de uma proposta baseada no Enfoque CiênciaTecnologia-Sociedade-Ambiente (CTSA). Ciência \& Ensino, v. 1, p. 1-12, 2007.

BLACK, D. \& GOLDOWSKY, A.. Science Theater as an interpretive technique in a science museum. Paper presented at the meeting of the National Association of Research in Science Teaching, Boston, MA, 1999.

BIÃO, A. J. de C. Etnocenologia e a cena baiana: textos reunidos. Salvador: P\&A Gráfica e Editora, p. 389, 2009.

BOAL, A. Teatro do oprimido e outras poéticas políticas. Rio de Janeiro: Civilização Brasileira, 1980.

BODGAN, R. C. \& BIKLEN, S. K. Investigação qualitativa em educação: uma introdução a teoria e aos métodos. Porto: Porto editora, 1994.

BIANCONI, M. L.; CARUSO, F. Educação Não-Forma. Ciência e Cultura, vol.57 n. 4 São Paulo Out./Dez. 2005.

BRITO, F. FERREIRA, J.R. MASSARANI, L. Centros e Museus de Ciências do Brasil 2009. Rio de Janeiro: Associação Brasileira de Centros e Museus de Ciências: UFRJ. FCC, Casa da Ciência: Fiocruz. Museu da Vida, 2009.

BROCKINGTON, G. e PIETROCOLA, M. Serão as regras da transposição didática aplicáveis aos conceitos de física moderna? Investigações em Ensino de Ciências V10(3), pp. 387-404, 2005.

BROUWER, W. The image of the physicist in modern drama. American Journal of Physics. Volume 56, Issue 7, pp. 611-617, July 1988.

BROUWER, W. The image of the physicist in modern drama (Part 2). American Journal of Physics, v. 62, n 3, p. 234-240, 1994.

BYBEE, R. W. Science education and the science-technology-society (STS) theme. Science Education, v. 71, n. 5, p.667-683, 1987.

BYBEE, R. W. Achieving scientific literacy. The Science Teacher. Arlington: United States. V. 62, n. 7, oct, 1995, p. 28-33.

CAZELLI, S. Alfabetização científica e os museus interativos de ciências. Dissertação PUC-RJ, Rio de Janeiro, 1992.

CAZELLI, S.; FRANCO, C. Alfabetismo científico: novos desafios no contexto da globalização. Ensaio, v. 3, n. 1, p. 12-25, 2001.

CAZELLI, S.; GOUVÊA, G.; FRANCO, C. Aprendizagem compartilhada em museus interativos de ciência. Cadernos de Memória Cultural, Rio de Janeiro, v. 4, p. 128-132, 1999.

CAZELLI, S. Divulgação Científica em espaços não formais. Anais do XXIV Congresso da Sociedade de Zoologia do Brasil, Belo Horizonte, p. 10-10, 2000.

CAZELLI, S. Ciência, cultura, museus, jovens e escolas: Quais suas relações? Tese. Faculdade de Educação, PUC, Rio de Janeiro, 2005.

CHAGAS, I. Aprendizagem não-formal/formal das ciências: relação entre museus de ciências e as escolas. Revista de Educação, Lisboa, v. 3, n. 1, 1993. p. 51-59. 
CHALMERS, A. F. A fabricação da ciência. São Paulo: Editora da Universidade Estadual Paulista, 1994.

CHASSOT, A. Alfabetização Científica: questões e desafios para a educação. 3a ed. Ijuí: Unijuí, 2003a, p. 438.

CHASSOT, A. Educação consciência. Santa Cruz do Sul: UNISC, 2003b, p. 243.

CHEVALLARD, Yves. La transposición didáctica del saber sábio al saber enseñado. Tradução de Claudia Gilman. 3.ed. Buenos Aires: Aique 1998.

COLLEY, H.; HODKINSON, P. \& MALCOLM, J. Non-formal learning: mapping the conceptual terrain. A consultation report, Leeds: University of Leeds Lifelong Learning Institute. 2002. Disponível no endereço: http://www.infed.org/archives/etexts/colley_informal_learning.htm

CONSTANTIN, A. C. C. Museus interativos de ciências: espaços complementares de educação? Interciência, maio, vol. 26, n 5, p. 195-200, 2001.

COUTINHO-SILVA, R.; PERSECHINI, P. M.; MASUDA, M. e KUTENBACH, E. Interação museu de ciências-universidade: contribuições para o ensino não-formal de ciências. Cienc. Cult., vol.57, n.4, p. 24-25, 2005.

CUOMO, F. Berliner Ensemble 1957 - Piccolo Teatro 1963. Science in the reception of Brecht's Galileo as from the press reviews on both stagings. Journal of Science Communication. 5 (1), march, 2006.

DÍAZ, J. V. Divulgación Cientifica y Democracia. Alambique, p. 17-25, ano VI, Julio, 1999.

DJERASSI, K.; HOFFMAN, R. Oxigênio. Rio de Janeiro: Vieira \& Lent, 2004.

DIERKING, Lynn D.. Lições sem limite: como o aprendizado por livre escolha vem transformando a educação em ciência e tecnologia. Hist. cienc. saude-Manguinhos. 2005, vol.12, suppl., pp. 145-160.

DURANT, J. Participatory technology assessment and the democratic model of the public understanding of science. Science and Public Policy, v.26 (5), p. 313-319, 1999.

FREIRE, P. Educação como prática da liberdade. $10^{\circ}$ ed. Rio de Janeiro: Paz e Terra, 1980, p. 150.

FALK, J. H. The contribution of free-choice learning to public understanding of science. INCI, v.27, no.2, p.62-65, feb., 2002

FÁVERO, O. Educação não-formal: contextos, percursos e sujeitos. Educ. Soc., Campinas, vol. 28, n. 99, p. 614-617, maio/ago. 2007.

FLEMING, R.W. (1989). Literacy for a technological age. Science Education, 73(4), pp. 391-404.

FRAZZETTO, G. Science on the stage. European Molecular Biology Organization, v. 3, n 9, 2002, p. 818-820.

FREIRE, P. Pedagogia da autonomia: saberes necessários à prática educativa. São Paulo: Paz e Terra, 1996, p. 165.

FOUREZ, G. A construção das ciências: introdução à filosofia e à ética das ciências. São Paulo: Editora da Universidade Estadual Paulista,1995. 
GARDAIR, T. L. C. \& SCHALL, V. T. Ciências possíveis em Machado de Assis: teatro e ciência na educação científica. Ciência \& Educação, v. 15, n. 3, p. 695-712, 2009.

GASPAR, A. O ensino informal de ciências: de sua viabilidade e interação com o ensino formal à concepção de um centro de ciências. Cad. Cat. Ens. Fis., v.9, n.2, p.157-163, ago.1992.

GILBERT, J. K. Educación Tecnológica: Una Nueva Asignatura En Todo El Mundo. Enseñanza de las Ciencias, 1995, Vol. 13 (1): 15-24.

GOUVÊA, G.; LEAL, M. C. Uma visão comparada do ensino em ciência, tecnologia e sociedade na escola e em um museu de ciência. Ciência \& Educação, v.7, n.1, p.67-84, 2001.

GRUZMAN, C. E SIQUEIRA, V. H. F. O papel educacional do museu de ciências: desafios e transformações conceituais. Revista Electrónica de Enseñanza de las Ciencias Vol. 6, No 2, 402-423, 2007.

GUNDERSON, L. (2006). Science plays come of age. The Scientist. Disponível em: http://www.the-scientist.com/news/display/24160/. Acessado em 23/04/2011.

HAZEN, R. M. \& TREFIL J. Saber ciência. São Paulo: Cultura Editores Associados, 1995, p. 430.

HOFSTEIN, A., AIKENHEAD, G., RIQUARTS, K. (1988). Discussions over STS at the fourth IOSTE symposium. International Journal of Science Education, v. 10, n. 4, p.357-366.

HOLMAN, J. Editor's introduction: Science-technology-society education. International Journal of Science Education, v. 10, n. 4, p.343-345, 1988.

HURD, P.D. Scientific Literacy: New Minds for a Changing World, Science Education, v. 82, n. 3, 407-416, 1998.

IGLESIA, P. M. Ciencia-Tecnología-Sociedad en la enseñanza-aprendizaje de las ciencias experimentales. Alambique dicáctica de las ciencias experimentales, v. 2, n. 3, p.7- 11, 1995.

International Council of Museums - ICOM. Article II - Definição. Estatuto aprovado pela 20 Assembléia Geral. Espanha: julho de 2001. Na web: http://icom.museum/definition.html (consultado em janeiro de 2012).

JACOBUCCI, D. F. C. Contribuições dos espaços não-formais de educação para a formação da cultura científica. EM EXTENSÃO, Uberlândia, V. 7, 2008, p. 55-66.

JAPIASSU, H. Um desafio à educação: repensar a pedagogia científica. São Paulo: Letras \& Letras, 1999.

KOUDELA, I.D. Brecht: Um jogo de aprendizagem. São Paulo: Perspectiva, p. 208, 1991.

KIOURANIS, N. M. M.; SOUSA A. R.; FILHO, O. S. Alguns aspectos da transposição de uma sequência didática sobre o comportamento de partículas e ondas. Revista Electrónica de Enseñanza de las Ciencias Vol. 9, N 1, 199-224, 2010.

KRASILCHIK, M.; MARANDINO, M. Ensino de Ciências e cidadania. São Paulo: Moderna. 2001. 
KUHN, T. S. A estrutura das revoluções científicas. 3. a edição. São Paulo: Perspectiva, 2000.

LAUGKSCH, R.C. Scientific Literacy: A Conceptual Overview, Science Education, v.84, n.1, 71-94, 2000.

LATOUR, B., WOOLGAR, S. A vida de laboratório: a produção dos fatos científicos. Rio de Janeiro: Relume Dumará, 1997.

LEAL, M. C.; SOUZA, G. G. Mito, ciência e tecnologia no ensino de ciências: o tempo da escola e do museu. In: Atlas do I Encontro Nacional de Pesquisa em Ensino de Ciências, Águas de Lindóia-SP, nov, 1997, p.27-29.

LEWENSTEIN, B. V. Models of Public Communication of Science and Technology. No ar desde 2003. Disponível em: <http://communityrisks.cornell.edu/BackgroundMaterials/Lewenstein2003.pdf. Acessado em: 20/08/2010.

LOPES, T. Discutindo ciência em cena por meio do teatro. Presença Pedagógica. Editora Dimensão,n. 31, jan.-fev, 2000.

LOPES, T. Luz, arte, ciência... ação! História, Ciências, Saúde - Manguinhos, v. 12(suplemento), p. 401-18, 2005.

LORENZETTI, L. \& DELIZOICOV, D. Alfabetização Científica no Contexto das Séries Iniciais. Ensaio - Pesquisa em Educação em Ciências. V. 3, n. 1, jun, 2001, p. 1 17.

LOUREIRO, J. M. M. Museu de ciência, divulgação científica e hegemonia. Ci. Inf. Brasília. V. 32, n. 1, jan./abr, 2003, p. 88-95.

LÜDKE, M; ANDRÉ, M. E. D. A. Pesquisa em Educação: abordagens qualitativas. São Paulo: EPU, 1986.

LUPETTI, K. O. et al. Além da lenda: entretenimento para divulgação de ciência e cultura. In: XIII Encontro Nacional de Ensino de Química: Educação em Química no Brasil, 25 anos de ENEQ. Caderno de resumos. Campinas, 2006.

LUPETTI, K. Ouroboros: a linguagem teatral para ensinar ciência e cultura. In: XLVII Congresso Brasileiro de Química-CBQ: Recursos não renováveis. Caderno de resumos. Natal., 2007a.

LUPETTI, K. Magia X Ciência: teatro para divulgação científica e ensino de química. In: 30a Reunião Anual da Sociedade Brasileira de Química. Caderno de resumos Águas de Lindóia, 2007b.

LUPETTI, K. Ouroboros: entretenimento e informação. In: VI Encontro de Extensão:Conhecimento e Diversidade Cultural. Caderno de resumos. São Carlos, 2007c.

LUPETTI, K. O.; SERAFIM, T. G.; PUGLIERE, T. S.; LIMA; L. P.; ALMEIDA, L. F.; MACEDO, A. N.; RODRIGUES, C.; PEREIRA, T. M.; GROMBONI, M. F.; MOURA, A. F.; MARQUES, C. M. de P. Ciência em cena: teatro e divulgação científica. XIV Encontro Nacional de Ensino de Química (ENEQ). Conhecimento Químico: Desafios e Possibilidades da Pesquisa e da Ação Docente, 2008. Disponível em: www.quimica.ufpr.br/eduquim/eneq2008/resumos/R0790-1.pdf. Acessado em: 04/06/2011. 
MAARSCHALK, J. Scientific literacy and informal science teaching. J Res. Sci. Teac., 25, 135-146, 1988.

MAGNI, F. The theatrical communic - action of science. Jekyll.comm 1, Mar 2002. Disponível em: http://jekyll.comm.sissa.it/articoli/art01_04_eng.pdf. Acessado em: 23/04/2011.

MARANDINO, M. O Ensino de Ciências e a Perspectiva da Didática Crítica. Rio de Janeiro. PUC/RJ, 1994, p. 288.

MARANDINO, M. O Conhecimento Biológico nas Exposições de Museus de Ciências: análise do processo de construção do discurso expositivo. São Paulo, FEUSP, 2001

MARANDINO, M. ; SILVEIRA, R. V. M. ; CHELINI, M. J. E. ; FERNANDES, A. B. ; GARCIA, V. A. R. ; MARTINS, L. C. ; LOURENÇO, M. F. ; FERNANDES, J. A. ; FLORENTINO, H. A. . A Educação Não Formal e a Divulgação Científica: o que pensa quem faz?. In: IV Encontro Nacional de Pesquisa em Ensino de Ciências - ENPEC, 2004, Bauru. Atas do IV Encontro Nacional de Pesquisa em Ensino de Ciências ENPEC, 2004.

MARANDINO, M. A pesquisa educacional e a produção de saberes nos museus de ciência. Hist. Ciênc. Saúde Manguinhos, Rio de Janeiro, v. 12, p. 161-181, 2005.

MARANDINO, M. Museu como lugar de cidadania. Salto para o Futuro, v. Ano XIX, p. 29-35, 2009.

MATEUS, A. L. et al, Frankenstein: Ensinando Ciência através da arte. XVI Simpósio Nacional do Ensino de Física. Rio de Janeiro. 2005. Disponível em: http://www.sbf1.sbfisica.org.br/eventos/snef/xvi/cd/resumos/T0351-1.pdf. Acessado em: 17/04/2008.

MATOS, C. (Org.) Ciência e Arte: imaginário e descoberta. São Paulo: Terceira Margem, 2003.

MASSARANI, L. A divulgação científica no Rio de Janeiro: Algumas reflexões sobre a década de 20. Dissertação. Universidade Federal do Rio de Janeiro. 1998.

MASSARANI, L.A divulgação científica, o marketing científico e o papel do divulgador. In: SOUZA,C.M. de (Org.), Comunicação ciência e sociedade: diálogos de fronteira. Taubaté: Cabral Editora e Livraria Universitária, 2004. p. 81-94.

MASSARANI, L. e ALMEIDA, C. Arte e Ciência no palco. Historia, Ciência e SaúdeManguinhos, v.13(suplemento), p. 233-246, out. 2006.

MASSARANI, L. Ciência e Criança: a divulgação científica para o público infantojuvenil. Rio de Janeiro: Museu da Vida, 2008.

MATOS, C. (Org.) Ciência e Arte: imaginário e descoberta. São Paulo: Terceira Margem, 2003.

MCMANUS, P. Topics in Museums and Science Education. Studies in Science Education, 20, 157-182, 1992.

MILICIC, B.; UTGES, G.; SALINAS, B.; SANJOSÉ, V. Transposición didáctica y dilemas de los profesores en la enseñanza de física para no físicos. Investigações em Ensino de Ciências, v13, n 1, p.7-33, 2008. 
MILLER, J. D. Scientific literacy: a conceptual and empirical review. Daedalus. N. 112, 1983, p. 29-48.

MONTENEGRO, B. et al. . O papel do teatro na divulgação científica: a experiência da seara da ciência. Cienc. Cult. , São Paulo, v. 57, n. 4, 2005 . Disponível em: $<$ http://cienciaecultura.bvs.br/scielo.php?script=sci_arttext\&pid=S0009-

67252005000400018\&lng=en\&nrm=iso>. Acessado em: 18/04/2008.

MOREIRA, L. M. Oxigênio: uma abordagem filosófica visando discussões acerca da educação em ciências - parte 1: poder e ambição. Ciência e Educação, vol.18, n.4, 2012, p. 803-818.

NAVAS, Ana Maria. Concepções de popularização da ciência e da tecnologia no discurso político: impactos nos museus de ciências. Dissertação de Mestrado. Faculdade de Educação/USP. 2008.

OLIVEIRA, N. \& ZANETIC, J. A presenca do teatro no ensino de física. XI Encontro Nacional de Pesquisa em Ensino de Física, comunicação oral, 2004.

PAVIS, P. Análise dos espetáculos. São Paulo: Editora Perspectiva, 2010.

PEDRETTI, E. G. Perspectives on Learning Through Research on Critical Issues-Based Science Center Exhibitions. Science Education, 88 (Suppl. 1):34- 47, 2004.

PELLA, M. O.; O’HEAM, G. T.; GALE, C. W. Referents to scientific literacy. Journal of Research in Science Teaching, 4, 199-208, 1966.

PÉREZ, C. A.; MOLINÍ, A. M. V. Consideraciones generales sobre la alfabetización científica en los museos de la ciencia como espacios educativos no formales. Revista Electrónica de Enseñanza de las Ciencias, Vol. 3, No 3, p. 339-362, 2004.

RIBEIRO, R. A. Divulgação científica e ensino de física: Intenções, funções e vertentes. Dissertação de Mestrado, Programa de Pós-Graduação Interunidades em Ensino de Ciências. São Paulo: IFUSP. 2007.

RICARDO, E. C. Educação CTSA: obstáculos e possibilidades para sua implementação no contexto escolar. Ciência \& Ensino, v. 01, p. 01-12, 2007.

ROGERS, A. Looking again at non-formal and informal education - Towards a new paradigm, 2004. Disponível em: http://www.infed.org/biblio/non_formal_paradigm.htm

ROSENTHAL, D. B. Two approaches to science - technology - society (STS) education. Science Education, v. 73, n. 5, p.581-589, 1989.

ROUBINE, J. J. A linguagem da encenação teatral. Rio de Janeiro: Zahar, 1998.

RYNGAERT, J. P. Introdução à análise do teatro. São Paulo: Martins Fontes, 1996.

SABBATINI, M. Museus e centros de ciência virtuais: uma nova fronteira para a cultura científica. Com Ciência. Disponível em: http://www.comciencia.br/reportagens/cultura/cultura14.shtml. Acesso em: 28 jul. 2003.

SANTOS, W. L. P.; MORTIMER, E. F. Uma análise de pressupostos teóricos da abordagem C-T-S (Ciência-Tecnologia-Sociedade) no contexto da educação brasileira. Ensaio - Pesquisa em Educação em Ciências, v. 2, n. 2, p. 1-23, 2000. 
SANTOS, W. P. dos \& SCHNETZLER, R. P. Educação em química: compromisso com a cidadania. 3a ed. Ijuí: Ed. Unijuí, 2003, p. 144.

SARAIVA, C.C. Teatro Científico e ensino da Química. Dissertação.Universidade do Porto. 2007.

SASSERON, L. H. e CARVALHO, A. M. P. Alfabetização científica no ensino fundamental: estrutura e indicadores deste processo em sala de aula. 2008. Tese (Doutorado) - Faculdade de Educação, Universidade de São Paulo, São Paulo, 2008.

SASSERON, L. H. e CARVALHO, A. M. P. Alfabetização científica: uma revisão bibliográfica. Investigações em Ensino de Ciências, V16(1), pp. 59-77, 2011.

SCHNETZLER, R. P. A pesquisa em ensino de química no Brasil: conquistas e perspectivas. Quim. Nova. V. 25, Supl. 1, 2002, p. 14-24.

SHAMOS, M. The Myth of Scientific Literacy. New Brunswick, NJ: Rutgers University Press, 1995.SHEN, B. S. P. Science Literacy. American Scientist. V. 63, may/jun, p. 265-268, 1975.

SILVEIRA, A. F.; SILVA, A. P. B.; FILHO, A. R. A divulgação da ciência através do teatro: um estudo em Copenhague de Michael Frayn. VII Enpec - Encontro Nacional de Pesquisadores em Educação em Ciências. 2009.

SIQUEIRA, M; JOSÉ, W. D.; KERBER, L.; SOARES, J. B.; JÚNIOR, J. S. "Vida de Galileu" - o teatro ressignificando a ciência/física. XIX Simpósio Nacional de Ensino de Física - SNEF 2011 - Manaus, AM. Disponível em: http://www.sbf1.sbfisica.org.br/eventos/snef/xix/sys/resumos/T0683-1.pdf. Acessado em 16/04/2011.

SMITH, M. K. Non formal. 2001. Disponível em: www.ifed.org/biblio/bnonfor.htm\#idea. Acessado em 25/04/2010.

SOARES, M. Letramento e Alfabetização: as muitas facetas. Texto apresentado na $26^{\mathbf{a}}$ Reunião da ANPED, Poços de Caldas, 2004. Disponível em: <http://www.anped.org.br/26/outrostextos/semagdasoares.doc >. Acessado em 18 de ago de 2006.

SOARES, M. S. M. A casa da Ciência da UFRJ como espaço de educação não formal. Monografia. Instituto Superior de Educação do Rio de Janeiro. 2003.

STEINGWEG, R. O modelo das peças didáticas: fontes, discussão, experiências. Trdução: Ingrid D. Koudela. Apostila não publicad, p. 26, 1991.

TAKAHASHI, R. H. C. A estrutura do conhecimento tecnológico do tipo científico. UFMG: Belo Horizonte, 2009.

VALENTE, M. E. A. O museu de ciência: espaço da história da ciência. Ciência \& Educação, v. 11, n. 1, p. 53-62, 2005.

VIEIRA, V. M. ; BIANCONI, L. ; DIAS, M. Espaços Não-Formais de Ensino e o Currículo de Ciências/Ciência e Cultura, vol.57 n. 4 São Paulo, Out./Dez. 2005.

VON LINSINGEN, I. O enfoque CTS e a educação tecnológica: origens, razões e convergências curriculares. XI Congreso Chileo de Ingeniería Mecânica - COCIM 2004, Antofagasta. Anais do COCIM 2004. v. 1. p. 1-11. Disponível em 
<http://www.nepet.ufsc.br/Artigos/Texto/CTS\%20e\%20EducTec.pdf>. Acesso em 09 Jul. 2011.

WAGENSBERG, J. Principios Fundamentales de la Museología Científica Moderna. Alambique, 26,15-19, 2000.

YAEL BAMBERGER, T. T. Levels of Choice in a Free Choice Learning Environment in Science and Natural History Museums. Science Education, aug, 2006, .p. 75-95.

YIN, R. K. Estudo de caso: Planejamento e métodos. Porto Alegre: Bookman, 2005, p.205.

ZANETIC, J. Física e Cultura. Ciência e Cultura. V. 57, n 3, São Paulo, jul/sep, 2005 Disponível em $\quad<\quad$ http://cienciaecultura.bvs.br/scielo.php?pid=S000967252005000300014\&script=sci_arttext $>$. Acessado em 10 de set de 2007.

ZOLLER, U. Decision-making in future science and technology curricula. European Journal of Science Education, v. 4, n. 1, p.11-17, 1982. 
Anexos 


\section{Anexo I: Questionário}

Levantamento das ações envolvendo Artes Cênicas desenvolvidas em Museus e Centros de Ciências brasileiros.

\section{I - Dados Institucionais}

Nome da Instituição:

Endereço: CEP: Telefone: ( ) Fax: ( ) E-mail: site:

Entrevistado (a): Formação: Cargo: Data: / / .

\section{II- Caracterização da Instituição}

1- Data de fundação da instituição:

2- Número total de visitantes no ano de 2010:

3- Em relação aos diferentes públicos, indique a quantidade em 2010.

( ) Público escolar - Quantidade

( ) Público espontâneo - Quantidade

( ) Outros: - Quantidade

\section{III- Investigando as Artes Cênicas nas instituições}

4 - Essa instituição realiza alguma atividade ligada às artes cênicas?

( ) Sim. ( ) Não.

5 - Se sim, qual (is)?

( ) Teatro. ( ) Contação de história. ( ) Esquetes. ( ) Improvisações. ( )

Performance. ( ) Dança. ( ) Teatro de fantoches.

Outros:

6 - A instituição contrata grupos que desenvolvem esse tipo de ação?

( ) Sim. ( ) Não.

7 - A instituição possui um setor de Artes Cênicas ou similar?

( ) Não

( ) Sim (indique o nome):

8- Quantas pessoas constituem a equipe do setor ou estão envolvidas com essas ações?

9 - Qual é a formação dos profissionais que constituem a equipe do setor ou ações?

\begin{tabular}{lllc} 
( ) Biólogo & ( ) Físico & ( ) Químico & ( ) Geólogo \\
( ) Pedagogo & ( ) Museólogo & ( ) Ator & ( ) Diretor de teatro \\
( ) Outros & & & \\
\hline
\end{tabular}

10 - Essa instituição realiza alguma formação específica para o desenvolvimento das ações ligadas às artes cênicas? Qual (is)?

11 - De acordo com a freqüência com que as ações de Artes Cênicas são oferecidas ao público, ela: 
( ) É uma atividade permanente. Periodicidade:

( ) É uma atividade eventual. Periodicidade:

12 - Que função as ações de Artes Cênicas assumem nessa instituição?

( ) Educativa ( ) Divulgação da ciência. ( ) Outro: Justifique sua opção.

13 - Em linhas gerais, como surgiu a ideia de desenvolver ações de artes cênicas nessa instituição? O trabalho foi inspirado em alguém?

14 - Qual a relação entre as ações de Artes Cênicas e o tema da exposição?

( ) O tema da exposição determina o tema das ações teatrais.

( ) O tema da exposição pode influenciar no tema das ações teatrais.

( ) O tema da exposição não interfere no tema das ações teatrais.

( ) Outro:

15 - Informações complementares: 


\section{Anexo II: Roteiro da entrevista}

Nome; Formação; Função na instituição

\section{Perguntas}

\section{1 - Caracterização do Projeto}

a) Quando iniciaram as atividades de teatro no museu? Quem coordenava? Qual era a equipe? Qual a formação?

b) Quais eram os objetivos deste projeto? Houve alterações desses objetivos ao longo do tempo? Quem hoje é responsável pelo projeto?

c) Quais atividades relacionadas às artes cênicas o projeto desenvolve? Qual a rotina de trabalhos do projeto?

d) A equipe do projeto é constituída por quantas pessoas? Qual o papel de cada um desses sujeitos neste projeto? Qual a formação destas pessoas?

\section{2 - O teatro no museu}

a) Por que fazer teatro dentro de um museu de ciências? O que motivou?

b) Quais aspectos caracterizam o teatro realizado no contexto de um museu de ciências?

c) Como você percebe a relação teatro, divulgação científica e educação dentro dos museus de ciências?

d) E com a arte, como você percebe a relação entre teatro em um museu de ciência e arte? $\mathrm{O}$ teatro continua sendo arte?

e) Em que medida o teatro realizado nos museus de ciências é uma ação de divulgação científica? E uma ação educativa? E uma manifestação artística?

f) Que aportes teóricos recebe o desenvolvimento do teatro no museu? De que campo de conhecimento advém tais aportes?

g) Que aspectos da cultura científica o teatro nos museus possui potencial para abordar? Por que você avalia que o teatro possui abordar esses aspectos e não outros?

h) As discussões sobre relação entre ciência e sociedade podem ser favorecidas ou promovidas por meio do teatro nos museus? Por que?

i) Quem define as questões, temas, conteúdos que compõem as propostas de teatro no museu? O público é ou deveria ser consultado nesse processo? Por que?

j) Ao seu ver, é desejável que exista alguma relação entre a peça e as demais atividades do museu - como a coleção, a exposição, a pesquisa científica, a conservação, entre outros aspectos? No caso deste museu, isso ocorre? Por que? 
k) Você considera que o teatro traz contribuição para as ações voltadas para o público nos museus de ciências? Que particularidades essa ação teria e que não poderia ser alcançado por outras atividades/ações?

\section{3 - A peça}

a) Qual a temática abordada na peça? Por que esse texto foi escolhido?

b) Como foi o processo criativo da peça? Quem participou e como?

d) Houve alguma dificuldade em trabalhar com esse texto? Quais?

e) Houve algum processo de preparação dos atores para a atuação nesse espetáculo? Se sim, como foi? Essa preparação incluiu aspectos relacionados ao entendimento de conceitos científicos?

f) O fato de ser uma peça com temática científica, no contexto do museu, influenciou no processo criativo? Como?

g) Como o espetáculo, enquanto encenação, contribui para a educação em ciências, para a divulgação científica e para a arte?

h) Este espetáculo veicula conceitos científicos? Quais?

i) Existe a preocupação em discutir a natureza da ciência, seus procedimentos e processos? Se sim, por que dessa preocupação? Como ela se traduz no espetáculo?

j) A aplicabilidade do conhecimento científico na resolução de questões do cotidiano é contemplada no espetáculo? Como?

k) Você considera que o espetáculo proporciona ao espectador reflexões que implique na mudança de hábitos, resultante do conhecimento da ciência? Como?

1) No espetáculo, como a ciência é caracterizada? Que concepção de ciência o espetáculo expressa?

m) Os conflitos, dúvidas e problemáticas são abordados?

n) Qual a visão de cientista que o espetáculo expressa?

o) O espetáculo possibilita uma visão do cientista para além do processo de produção científica stricto senso?

p) O lado "humano" da produção do conhecimento é abordado?

q) E os aspectos sociais da produção do conhecimento?

r) Na sua visão, como a peça se insere no contexto das discussões sobre alfabetização científica? Por que?

s) Ao longo da história desse grupo/projeto, quais foram as principais dificuldades encontradas?

É possível descrever uma linha de amadurecimento? 


\section{Anexo III: Questionário Pavis.}

\section{1 - Características Gerais da Encenação}

a. O sustenta os elementos do espetáculo (relações dos sistemas cênicos)

b. Coerência ou incoerência da encenação: em que se fundamenta?

c. Lugar da encenação no contexto cultural e estético.

d. O que perturba nessa encenação: que momentos fortes, fracos ou tediosos? Como se situa na produção atual?

\section{2 - Cenografia}

a. Formas do espaço urbano, arquitetural, cênico, gestual etc.

b. Relação entre espaço do público e espaço da representação.

c. Princípios da estruturação do espaço:

- Função dramatúrgica do espaço cênico e de sua ocupação.

- Relação do mostrado e do escondido.

- Ligação entre o espaço utilizado e a ficção do texto dramático encenado.

- Relação do explícito e do velado.

- Como evolui a cenografia? A que correspondem suas transformações?

d. Sistema das cores, das formas, das matérias: suas conotações.

3 - Sistema de iluminação

Natureza, ligação com a ficção, com a representação, com o ator. Efeitos sobre a recepção do espetáculo.

4 - Objetos

Natureza, função, matéria, relação com o espaço e com o corpo, sistema de seu emprego.

5 - Figurinos, maquiagens, máscaras

Função, sistema e relação com o corpo.

6 - Performance dos atores

a. Descrição física dos atores (gestual, mímica, maquiagem); mudanças em sua aparência.

b. Sinestesia presumida dos atores, sinestesia induzida no observador.

c. Construção de personagem; ator/papel.

d. Relação do ator e do grupo: deslocamentos, relações de conjunto, trajetória.

e. Relação texto/corpo.

f. Voz: qualidades, efeitos, produzidos, relação com a dicção e canto.

g. Estatuto do ator: seu passado, sua situação na profissão etc.

7 - Função da música, do barulho, do silêncio.

a. Natureza e características: relação com a fábula, com a dicção.

b. Em que momentos intervêm? Consequências para o resto da representação.

8 - ritmo do espetáculo

a. Ritmo de alguns sistemas significantes (trocas de diálogos, iluminação,figurinos, gestualidade etc.) Ligação entre duração real e duração vivida.

b. O ritmo global do espetáculo: ritmo contínuo ou descontínuo, mudanças de regime, ligação co encenação.

9. Leitura da fábula por esta encenação

a. Que história é contada? Resuma-a. A encenação conta a mesma coisa que o texto.

b. Quais escolhas dramatúrgicas? Coerência ou incoerência da leitura? 
c. Que ambiguidades no texto, que esclarecimentos na encenação?

d. Que organização da fábula?

e. Como a fábula é construída pelo ator e a cena?

f. Qual é o gênero do texto dramático segundo essa encenação?

g. Outras opções de encenação possíveis.

10 - O texto na encenação

a. Escolha da versão cênica: quais modificações?

b. Características da tradução (quando houver). Tradução, adaptação, reescrita ou escrita original?

c. Que lugar a encenação atribui ao texto dramático?

d. Relações do texto e da imagem, do ouvido e do olho.

$11-\mathrm{O}$ espectador

a. No interior de que instituição teatral se situa essa encenação?

b. Que expectativas você tinha desse espetáculo (texto, encenação, atores)?

c. Que pressupostos são necessários para apreciar esse espetáculo?

d. Como reagiu o público?

e. Papel do espectador na produção do sentido. A leitura encorajada é unívoca ou plural?

f. Que imagens, que cenas, que temas o desafiam e permanecem com você?

g. Como a atenção do espectador é manipulada pela encenação?

12 - Como anotar (fotografar ou filmar) esse espetáculo? Como conservar sua lembrança? O que escapa à anotação?

13 - O que não é semiotizável.

a. Aquilo que na leitura da encenação não fez sentido.

b. O que não é redutível ao signo e ao sentido (e por que).

14 - Balanço

a. Quais os problemas particulares a serem examinados?

b. Outras observações, outras categorias para essa encenação e para o questionário. 